Portland State University

PDXScholar

Summer 9-5-2014

\title{
"Del Campo Ya Pasamos a Otras Cosas-From the Field We Move on to Other Things": Ethnic Mexican Narrators and Latino Community Histories in Washington County, Oregon
}

Luke Sprunger

Portland State University

Follow this and additional works at: https://pdxscholar.library.pdx.edu/open_access_etds

Part of the History Commons

Let us know how access to this document benefits you.

\section{Recommended Citation}

Sprunger, Luke, "'Del Campo Ya Pasamos a Otras Cosas--From the Field We Move on to Other Things": Ethnic Mexican Narrators and Latino Community Histories in Washington County, Oregon" (2014). Dissertations and Theses. Paper 1977.

https://doi.org/10.15760/etd.1977

This Thesis is brought to you for free and open access. It has been accepted for inclusion in Dissertations and Theses by an authorized administrator of PDXScholar. Please contact us if we can make this document more accessible: pdxscholar@pdx.edu. 
"Del Campo Ya Pasamos a Otras Cosas-

From the Field We Move On to Other Things":

Ethnic Mexican Narrators and Latino Community Histories in

Washington County, Oregon

by
Luke Sprunger

A thesis submitted in partial fulfillment of the requirements for the degree of

Master of Arts

in

History

Thesis Committee:

Katrine Barber, Chair

Roberto De Anda

David Johnson

Patricia Schechter

Portland State University

2014 
(C) 2014 Luke Sprunger 


\begin{abstract}
This work examines the histories of the Latino population of Washington County, Oregon, and explores how and why ethnic Mexican and other Latino individuals and families relocated to the county. It relies heavily on oral history interviews conducted by the author with ethnic Mexican residents, and on archival newspaper sources. Beginning with the settlement of a small number of tejano families and the formation of an ethnic community in the 1960s, a number of factors encouraged an increasing number of migrant Latino families-from tejanos to Mexican nationals to Central and South Americans to indigenous migrants of various nationalities-to settle permanently in the county. This work studies how the growth and diversification of the population altered the nature of community among Latinos, how changing social conditions and the efforts of early community builders improved opportunities for new arrivals, and how continuing migration has assisted in processes of cultural replenishment.
\end{abstract}




\section{Acknowledgements}

Thank you to the following individuals for your kind assistance with this project: Emily-Jane Dawson, Beth Dehn, Karen Hill, José Jaime, Carlos Lopez, Jeralynn Ness, Ilene O’Malley, Jose Pastrano, José Rivera, Amie Thurber, and Pat Yama.

Thank you to my narrators for your patience and generosity in working with me before, during, and after the interview and transcription processes. My work would not have been possible without you. Fue un placer conocerlos a ustedes: Eduardo Corona, Laura Gamboa, Giores, Hector Hinojosa, Sister Ina Marie Nosack, Ariadna Covarrubias Ornelas, Evangelina Sanchez, Enedelia Hernandez Schofield, and Arturo Villaseñor.

Thank you to my thesis committee members-Roberto De Anda, David Johnson, and Patricia Schechter-for your helpful feedback and research suggestions.

To Katrine Barber, my advisor: Thank you for your encouragement, for your recommendations, and for taking time out of your already overly busy schedule to guide me along the research and writing processes. I am sincerely grateful for your help in seeing my thesis work through from start to finish. 


\section{Table of Contents}

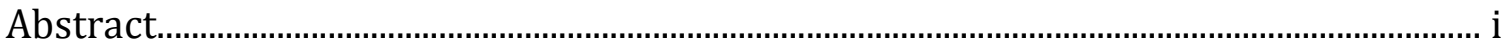

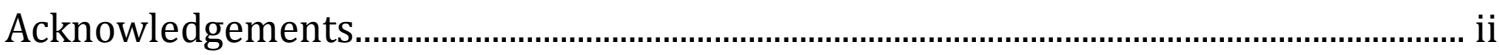

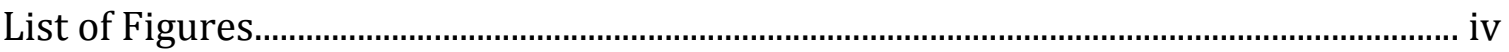

Introduction

Chapter I: Tejanos and Community Formation in the 1960s and 1970s....................... 38

Chapter II: Growing Mexican and Latino Populations of the 1970s and 1980s.......... 90

Chapter III: Mexican Immigrants in the 1990s, 2000s, and 2010s.............................. 126

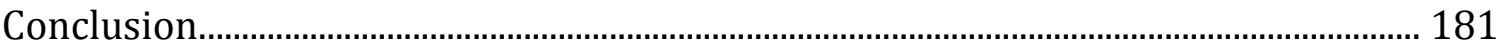

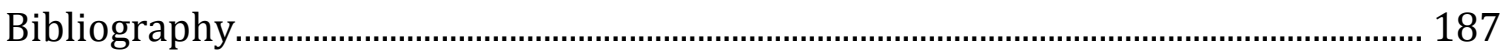

Appendix A: Human Subjects Research Review Committee Approval......................... 195 


\section{List of Figures}

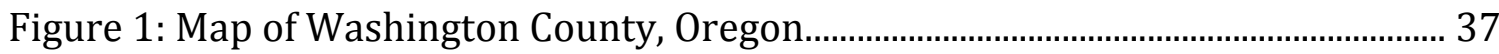




\section{Introduction}

\section{Terminology}

This work uses a variety of terms to refer to people of different ethnic, cultural, and national backgrounds. Ethnic Mexican is used to refer to people who were either born in Mexico or who had ancestors from Mexico. It encompasses both recent arrivals from Mexico and those whose families have been living in the United States for generations. Tejano refers to individuals and families who resided long enough in Texas to identify with the ethnic Mexican culture that developed there. Mexican national and Mexican immigrant refer to people who relocated from Mexico in their lifetimes. These terms are not synonymous with undocumentedsome of these people have obtained residency or citizenship status in the United States. Mexican American refers to people who are ethnically Mexican, but are U.S. citizens; in this work, it is used to refer to people who were born in the United States or were brought to the United States at a very young age and would self-identify as "Mexican American." Chicano, a term used by some Mexican Americans to selfidentify, is only used in this work in reference to the Chicano Movement of the late 1960s and 1970s and the activism it inspired, and where the term is used as part of an academic designation.

As someone who left Mexico before he was old enough to remember much about it and was raised in Texas and then Oregon, narrator Hector Hinojosa's life highlights how terms such as tejano, Mexican immigrant, and Mexican American can serve as only imperfect titular designations. Nationality and citizenship status have an important bearing on one's life opportunities in the United States, but they do not 
always correspond with where an individual was raised and with what culture he or she identifies. National and regional identities can become complex and multifaceted among those whose lives have been shaped by migration. In this work, Hinojosa is a tejano, a Mexican immigrant, and (having obtained his citizenship in the 1970s), a Mexican American.

White is used to refer to non-Latinos of European ancestry. In this work it is synonymous with the more cumbersome designation, "non-Latino white." Some narrators used Americano, Norteamericano, or American in reference to nonLatino whites. Latino refers to anyone of Latin American origin or ancestry, regardless of nationality and regardless of what race (such as "white") with which they might identify if asked. Latino is used in this work to include people from indigenous communities in Latin America, whether they speak Spanish or not. Hispanic is used less frequently in this work, generally when referencing quotes or population figures or other types of statistical data where this term is employed. It is used as roughly synonymous with "Latino."

In the Spanish language, surnames do not receive an "s" or "es" on the end of the name when referred to in plural. I have preserved this rule. For example, "the Hernandez" and "the Hinojosa" are used instead of "the Hernandezes" or "the Hinojosas." I refer to Enedelia Schofield, who took her husband's last name, as "Enedelia Hernandez Schofield" in this work to clarify and highlight her connection to her parents, Emilio and Hortencia Hernandez. Accents on names are used in consistency with print sources and/or how individuals and organizations stylize 
names. Some ethnic Mexicans residing in the United States have dropped accents from their surnames. Such changes are preserved here.

I use Southwest or southwestern states in the broad sense of the term to refer to those places-California, Arizona, New Mexico, Colorado, and Texas-that have had significant resident populations of ethnic Mexicans since the United States took possession of the region following war with Mexico in the late 1840s.

\section{Project origins/methodology}

I began my thesis work with more curiosity than knowledge about the ethnic Mexican and Latino populations of Washington County. Completing a Spanish major as an undergraduate gave me some command of the language and exposure to a diverse body of Spanish-language literature from the U.S. Southwest, Mexico, and across Latin America. The literature introduced me to the different types of knowledge and the diversity of Spanish-speaking cultures and communities. Having met both immigrants from Latin America who continued to struggle with English and ethnic Mexican U.S. citizens who lamented not being taught the language of their parents or grandparents, I was curious as to how linguistic, as well as cultural, adaptation and preservation played out in an area with a relatively large settled Latino population. After relocating from Michigan and Indiana to Portland, Oregon, to begin work for the Master of Arts program in history at Portland State University, I looked to Washington County and its small cities and towns to begin to explore the many facets of ethnic Mexican/Latino history there.

Situated just west of Portland's Multnomah County, Washington County is a mix of rural and urban areas. Beaverton, on the eastern edge of the county, is 
centered only seven miles west of downtown Portland and is home to the headquarters for Nike, Inc., and a number of technology companies; small cities and towns dot the central part of the county, while the western part of the county is largely rural. The central and eastern parts of the county continue to develop an increasingly suburban relationship to Portland, as evidenced by the light rail lines that connect Hillsboro, the largest city in the county at just over 91,000 residents as of the 2010 census, to Portland, roughly fifteen miles away, via a forty-five minute train ride.

Important agricultural areas lie outside of the cities and communities of (from west to east) Forest Grove, Cornelius, Hillsboro, Aloha, and Beaverton. After relying on the labor of Mexican men as part of the bracero $^{1}$ program during World War II, farm owners and operators in the county sought Latinos from both the United States and abroad for seasonal agricultural work. Beginning with the settlement of a small number of tejano families and the formation of an ethnic community in the 1960 s, a number of factors encouraged migrant Latino familiesfrom tejanos to Mexican nationals to Central and South Americans and indigenous migrants of various nationalities-to settle permanently in the county in increasing numbers.

My work was made possible through an expanding network of contacts. Professor Katrine Barber helped put me in touch with Beth Dehn, curator of education and folklife at the Washington County Museum, and together we

1 "Bracero" in Spanish refers to someone who works with his arms (brazos), in reference to manual labor. 
developed a plan that facilitated my research and contributed oral histories to the museum's existing Latino history collection. Dehn and the museum staff recognized that the histories of ethnic Mexicans, who comprise roughly four-fifths of the recorded Latino population in the county, and other Latinos were underrepresented at the museum. Interviews with Latino residents, including some of those who had prominent roles in building community and mutual aid organizations in the county, would both provide sources for studying the history of this population (in the interviews themselves) and would put the museum in touch with individuals who could direct the staff to other primary sources to assist in the creation of future projects focusing on the history of this population.

I started my research with broad questions about the nature of the county's Spanish-speaking population, its challenges, and its successes. With respect to oral history, my approach aligned with the goals of the museum staff. I felt that the best way to develop more focused questions and lines of inquiry about the history of this population was to talk to residents themselves and those who served as allies. I prepared focused questions for narrators while also giving them the freedom to elaborate on developments they found important in personal and community history.

In addition to providing me with recording equipment, a physical location to conduct the interviews, and servers to store the interviews on, Dehn also put me in 
touch with several important community contacts. ${ }^{2}$ Some of these contacts served as narrators for interviews, while others directed me to narrators. In all, I completed one interview each with nine narrators-eight were ethnic Mexicans residing in Washington County, and the other was a retired nun who had worked with Spanishspeaking and migrant families. The interviews were conducted between May and November of 2013. I also utilized three existing interviews that had been conducted by Michael O’Rourke for the Washington County Museum in 2000 and 2001—one with narrator Hector Hinojosa, one with narrator Enedelia Hernandez Schofield, and one with Enedelia's father, Emilio Hernandez.

\section{Community contacts/interviews}

Through Dehn and the museum, I arranged for and conducted an oral history interview with Sister Ina Marie Nosack, a retired nun who worked at Cornelius's St. Alexander Parish and with migrant farmworkers and their families during the 1980s and 1990s. They also put me in touch with José Jaime, a former priest who worked since the 1960s to assist the ethnic Mexican community. Jaime facilitated contact with tejano (those who grew up in Texas before moving to Oregon) residents of the county. I conducted interviews with three of them.

Dehn put me in touch with Amie Thurber, whose paper "The History of Latino People in Washington County: Weaving Community" used oral histories to examine Latino history in the county with a focus on the community building of the 1960s and 1970s. As I reviewed Thurber's work, spoke with community contacts,

2 In May 2014, the Washington County Museum earned a grant to fund the project of making the interviews available online through the museum's website. At the time of writing, in spring 2014, they can be accessed at the museum's Rock Creek location. 
conducted the first interviews, and examined published secondary sources covering ethnic Mexican history in different areas of the United States, I began to develop more focused questions about this population in the county.

The first members of a resident Latino population were arrivals from the U.S. Southwest-mostly from Texas. Washington County, like many other counties in western and midwestern states, saw an influx of tejanos in the decades after World War II as individuals and families migrated out of Texas to leave oppressive social structures behind and seek both seasonal and permanent employment opportunities unavailable in their home communities. The 1970s and afterward saw more and more people relocate directly from Mexico. Many of them eventually left agricultural work and established themselves permanently in Washington County.

The 1980s and subsequent decades saw the ever-increasing diversification of the Spanish-speaking population of Washington County, as new arrivals came from more diverse backgrounds and geographically distant communities of origin within Mexico and from other countries across Latin America. Poverty, social unrest, and/or armed conflict prompted many of these people to migrate to the United States. Some of the people I spoke with early on emphasized the initially tight-knit nature of the county's Spanish-speaking community established by the handful of tejano and other Mexican American families who resided in the county in the 1960s. It was evident that the substantial demographic growth of the Spanish-speaking population had altered the nature of this community-what was less clear to me was how this had occurred and what the implications of these changes were. 
As my research progressed, I kept the following questions in mind: How had the changing size and nature of the Latino population influenced the nature of community since the 1960s? How did the challenges faced by families who settled in the 1960s compare to those faced by families settling in the 1990s and 2000s? In what ways did differences of culture, nationality, and class between individuals and families of the growing Latino population affect community? Did the activism and community-building efforts of the first tejano families have a lasting impact on opportunities for county Latinos? What, if any, benefits did new arrivals confer on the community, and how did new and old residents alike identify with respect to their cultures and/or their communities of origin, and to English-speaking U.S. culture?

In looking at change over time, issues of ethnic tension and cohesion, and at what, if any, legacy or impact of the values of the initial community of the 1960s remained, I realized that I needed to interview not just tejanos who arrived in the 1960s but also people who had migrated in subsequent decades from Mexico. Reaching out to initial contacts helped begin a process of snowball sampling. Through Dehn and the museum, I was able to set up a meeting with José Rivera, the president of Centro Cultural of Washington County (located in Cornelius), an organization that provides aid to migrants and a variety of services to the Spanishspeaking population. Rivera recommended that I speak to Cornelius librarian Karen Hill. Hill put me in touch with one of the Mexican-born narrators.

Amie Thurber was kind enough to put me in touch with her stepmother Jeralynn Ness, the executive director of Community Action who had spent decades 
with the organization helping create opportunities for Latinos and other Washington County residents struggling with poverty. Ness had an extensive list of community contacts; through her introduction I was able to meet with four more immigrants from Mexico and arrange and conduct interviews with them. Two of these interviews were conducted in Spanish. The nine narrators involved in this project differ in their ages, countries of origin, occupations, and levels of formal education.

\section{Narrator biographies}

Hector Hinojosa (chapters I, III) was born in Matamoros, Tamaulipas, Mexico, and grew up in Harlingen, Texas. He first came to Oregon from California with his parents and siblings. The family settled permanently in Oregon in 1962 (before starting his fourth-grade year of school). Hector was living in Hillsboro at the time of the interview.

Evangelina Sanchez (chapters I, II, III) was born in Needville, Texas, and spent the first nineteen years of her life in Texas. She moved across the country seasonally with her family for work for several years. She relocated to Washington County in 1967 with her children, her mother, and her siblings. Evangelina was living in Hillsboro at the time of the interview.

Enedelia Hernandez Schofield (chapters I, II, III) was born in McAllen, Texas, in 1958 and moved to Washington County from California in 1962 with her parents, Emilio and Hortencia "Tencha" Hernandez, and her siblings. At the time of the interview, she was the principal of Butternut Creek Elementary School in Aloha. 
Sister Ina Marie Nosack (chapters II, III) was born in 1926 in Gervais, Oregon, and entered the convent of Sisters at Saint Mary after completing high school. Sister Ina Marie learned Spanish while working in Peru during the 1960s and 1970s. Years after returning to Oregon, she found that she wanted to continue using her Spanish and working with Latino families. She took a position at the St. Alexander Parish in Cornelius from 1984 to 1996; while working there she brought food and clothing to families living at migrant camps, helped families with childcare and other needs, and provided religious instruction to children at the parish. Sister Ina Marie was living in Beaverton at the time of the interview.

Laura Gamboa (chapters II, III) was born in Cuautla in the Mexican state of Morelos south of Mexico City and lived there until she was twenty-one years old. In 1990, Laura moved to Washington County with her two daughters to join her husband and her mother who had relocated there a short time earlier after spending about six months working in Madera, California. She was living in Aloha at the time of the interview, which was conducted in Spanish.

Arturo Villaseñor (chapters II, III) was born in Mexico in 1965. After graduating from Mexico City's Instituto Politécnico Nacional (National Polytechnic Institute), Arturo worked as a civil engineer. In 2000, Arturo moved to Washington County with his wife and children. He was living in Forest Grove at the time of the interview. Ariadna Covarrubias Ornelas (chapter III) was born in 1992 in the Mexican state of Michoacán and lived there until age ten. At that time her family relocated to Washington County to join her father, who had been working in the area for years. 
She earned an associate degree, and planned to eventually complete a Ph.D. in biochemistry. She was living in Cornelius at the time of the interview.

Eduardo Corona (chapter III) was born near Mexico City, and graduated from Mexico City's Universidad Autónoma Metropolitana (Metropolitan Autonomous University). After years of work in Mexico, he moved to California in 1999 to work for a U.S.-based company with multinational operations. A subsequent work opportunity brought him and his family to Beaverton, Oregon. A work transfer to Guadalajara had the family living in Mexico for several years before their return to Beaverton, where they have resided since 2010.

“Giores" (chapter III) was born in Colima, Mexico, and spent most of his adult life in Mexico City before relocating to the United States. Giores found life in Mexico City fast paced, uncertain, and stressful. After working at a number of different occupations there he left Mexico. A family connection brought him to Cornelius, Oregon, in 2007. This interview was conducted in Spanish.

\section{Notes on the interviews}

All interviews were conducted between May and November 2013. The translations of excerpts from the two Spanish-language interviews are my own. In some of the interviews, narrators spoke about the same or similar topics when responding to different questions. When these excerpts are from separate responses but pertinent to the same topic, they are placed next to one another as individually closed quotes. Any clarifications that I have made to the interviews have been added in brackets to the quoted material. Narrator Arturo Villaseñor made some clarifications to his interview; those clarifications have been added in parentheses. I 
have only otherwise altered quoted responses for consistency of style with the rest of the work.

\section{Sharing authority}

Working with community members and sharing authority are vital to the public historian, and especially so when the public historian and the people she or he is working with are of other ethnic or cultural backgrounds. According to public and oral historian Michael Frisch in A Shared Authority: Essays on the Craft and Meaning of Oral and Public History (1990), oral history “can contribute a substantial counter to officially received history and officially defined policy, by empowering people to generate alternative understandings and approaches." 3 One does not need to look very hard for evidence of how even data sets generally considered to be authoritative and objective have not adequately provided a portrait of Latinosshifting terminology and designations for people of Latin American origin in the decennial U.S. censuses throughout the twentieth century highlight the ways that non-Latino whites have struggled to place ethnic Mexicans and people from other predominantly Spanish-speaking nations into imperfect ethnic and racial categories. In "A Demographic Profile of Chicanos in the Pacific Northwest," in Carlos Maldonado and Gilberto Garcia's volume The Chicano Experience in the Northwest, Guadalupe Friaz described the various and inconsistent strategies to identify Hispanic or Latino people:

${ }^{3}$ Michael Frisch, A Shared Authority: Essays on the Craft and meaning of Oral and Public History (Albany: State University of New York Press, 1990), 178. 
Hispanics do not have a singular characteristic that ties them together as Hispanic. They do not share one language, nationality, or ascriptive trait. Latinos have been counted on the basis of Spanish surname, Spanish Heritage, and Spanish language, to name a few identifiers. The number of Hispanics varies with the specific identifier. The inconsistencies in identifiers makes comparisons with previous census figure difficult. Not until the 1980 census was there a single definition of Hispanic used nationwide for the entire population. ${ }^{4}$

Even after the census attempted to outline the Hispanic or Latino population by asking respondents to self-report Hispanic/Latin American origin in 1980, the problem of undercounting members of the ethnic group persisted. ${ }^{5}$ The repeated failure of the U.S. Census Bureau to compile accurate data on the Latino population suggests that—owing to linguistic differences and the marginalized statuses held by many members of these ethnic groups-data on Latinos is inaccurate or incomplete in other official records as well. While oral histories cannot be used to fill in missing data sets, they can speak to the experiences of people that have been underrepresented or ignored by other source materials. For many of my data sets, I have used population figures as provided by Woods \& Poole Economics, Inc., a Washington, D.C.-based organization with county-level databases of economic and demographic statistics. Their population figures, generally higher than the figures from the census bureau by roughly one percent or less, are still likely lower than the actual historical and contemporary numbers of Latinos in the county.

${ }^{4}$ Guadalupe Friaz, "A Demographic Profile of Chicanos in the Pacific Northwest," in The Chicano Experience in the Northwest, edited by Carlos B. Maldonado and Gilberto Garcia (Dubuque, Iowa: Kendall-Hunt Publishing Company, 1995), 36.

5 Friaz, "A Demographic Profile of Chicanos in the Pacific Northwest," 37. 
As members of a minority and marginalized population, Washington County Latinos have had comparatively few opportunities to publicly share their personal histories and contemporary struggles. When Enedelia Hernandez Schofield's family purchased a home in Forest Grove in 1967, a television news crew was sent to report-a reporter interviewed the neighbors, interested in how that family of nonLatino whites felt about living next to a family of ethnic Mexicans. The news crew was not concerned with the opinions and experiences of the Hernandez family. Even where their stories have not been ignored, newspaper sources and existing scholarship cannot speak to the experiences and hardships that narrators and their families faced in the ways that narrators can themselves.

Frisch also wrote about the potential of oral history to reach histories that would be otherwise inaccessible. ${ }^{6}$ The oral history interviews I conducted helped explore specific reasons that narrator families chose to relocate, as well as the longterm and daily realities that they faced in Washington County. Their interviews give voice both to how discrimination has operated against them and to how identity formation and cultural replenishment take place in ways that print sources largely cannot.

In Recording Oral History: A Guide for the Humanities and Social Sciences (2005), Valerie Raleigh Yow described the process of the interview and the product of the finished interview as a "collaboration"; the interviewer brings knowledge of the research process and practices, while the narrator brings knowledge of his or her cultural background and personal and family histories. "The term used to

${ }^{6}$ Frisch, A Shared Authority, 186. 
describe the dynamic is 'shared authority."'7 While Yow acknowledged that generalizations based off of oral history interviews could be made with less confidence than generalizations based off of more quantitative data sets and research techniques, she echoed Frisch in asserting that it is a vital research medium for "obtaining a picture of total society because the viewpoints of the nonelite who do not leave memoirs or have biographers are presented."8 Furthermore, the collaborative nature of the interview process allowed narrators to identify aspects of their history that the researcher might have been ignorant or unaware of. "The researcher learns new things not found in the original hypothesis-in fact, many qualitative researchers do not form hypotheses at the beginning of the research."9 As I conducted my own work, narrators guided me toward topics, lines of inquiry, and sources that were important in better researching and analyzing their histories.

Catherine M. Lewis offered her views on shared authority in a different collaborative context in her book, The Changing Face of Public History: The Chicago Historical Society and the Transformation of an American Museum (2005). Writing about exhibits created in collaboration between museum staff and residents of Chicago neighborhoods, Lewis concluded that only a limited amount of authority could be shared with the non-academic public. "Museum professionals still control who has the right to participate at the most basic level. And they should; they have

\footnotetext{
${ }^{7}$ Valerie Raleigh Yow, Recording Oral History: A Guide for the Humanities and Social Sciences (Walnut Creek, Calif.: AltaMira Press, 2005), 2.

${ }^{8}$ Ibid., 11.

${ }^{9}$ Ibid., 6.
} 
the skills and experience to care for and interpret the artifacts that are important to the process of recording the past."10

While my project differed from the collaborative exhibits of the Chicago Historical Society, and while I sought to invite anyone of a Latino background living in Washington County to participate, I did not realize a complete sharing of authority with narrators. I was flexible on meeting times and venues for narrators, and I encouraged narrators to share any information or opinions that they liked, but in my process of seeking out narrators I was largely responsible for determining who ended up participating and which perspectives and personal histories were shared. In order to complete an interview, narrators had to be willing to complete the multi-step process that I outlined for them.

My lines of inquiry also shaped the nature of the interviews. I established the methods of conducting interviews and the parameters of the project-while I encouraged collaboration and the sharing of authority within the interview process and endeavored to make narrators feel both safe and respected, I did not share control over the structure of the interview process itself. Narrators likely felt limited in the ways that they could define their participation in order to complete a recorded oral history interview. The interview questions I chose to ask them guided the responses they shared.

A perfect sharing of authority can likely never be realized, and I exercised control over the interviews by picking the lines of inquiry and by selecting which

10 Catherine M. Lewis, The Changing Face of Public History: The Chicago Historical Society and the Transformation of an American Museum (DeKalb, Ill: Northern Illinois University Press, 2005), 120. 
narrators to speak with. I did at least invite narrators to share recollections and impressions on topics that might not have otherwise been addressed in the interview. The narrators helped me to form better research questions and think more broadly about the history of the community and population I was exploring.

\section{Interviewer impact and barriers to participation}

Kim Lacy Rogers's Life and Death in the Delta: African American Narratives of Violence, Resilience, and Social Change (2006) examined change over time in majority African American counties in the Mississippi Delta region and relied heavily on oral history interviews with African American narrators. It wove oral history excerpts between other source citations and analysis. The book, ordered in a fashion that is both thematic and chronological, was useful in figuring out how to arrange my own work. Complicating this study of change over time within the ethnic Mexican/Latino community in Washington County was the fact that this community, unlike the Mississippi Delta communities comprised of families who had long been permanently settled, was made and remade by successive waves of newcomers who transitioned from seasonal to permanent residence.

Rogers noted how the sex and ethnicity of the interviewer affected the responses of narrators in the interviews that she and her colleagues conducted. "Black men often talked more frankly with other black men about matters of sex, white harassment, and white targeting of black women than they did when I was present. African American women tended to describe intimate details of their childbirth and health experiences with another middle-aged woman than they did 
when a man was present [sic]."11 Many of the narrators for this project offered responses that seemed candid. They might have taken my grasp of the Spanish language, however imperfect, as a sign that I might be able to understand their difficulties of learning a second language and better understand the connection between language and one's sense of identity than if I had known English only. Most narrators spoke English very well or flawlessly, but they continued to assign the Spanish language a key position in their sense of self-identity. That I knew Spanish was one sign to narrators that I might try to understand and honor their perspectives, even if imperfectly.

Using a language I learned largely in academic settings could not erase or obscure the fact that I, a non-Latino white, had come from a different cultural and linguistic background than my narrators. There were some questions on which I felt the responses of certain narrators to be more guarded. Several of the Mexican immigrants offered only brief and limited responses on instances of discrimination. One declined to say that he felt discriminated against at all. Would the responses have been the same if the interviewer had been a fellow Mexican national, or if the interview was not going be made available to the general public? While I offer other potential reasons for these responses when examining this issue in chapter III, it is possible that my own position as a member of the numerically and socially dominant non-Latino English-speaking population-the population largely

${ }^{11}$ Kim Lacy Rogers, Life and Death in the Delta: African American Narratives of Violence, Resilience, and Social Change (New York: Palgrave Macmillan, 2006) 15. 
responsible for instances of discrimination against Latinos-made some narrators reluctant to speak on the topic.

It also needs to be considered that all narrators had either built successful careers for themselves or were in the process of improving their career and financial prospects through further education and training. While all narrators spoke about challenges for themselves and their families, overall their narratives suggested a belief in the possibility of socioeconomic progress in Washington County-however difficult that progress was to achieve. The outlook of these narrators likely affected the responses on questions regarding life opportunities in a positive manner.

I scheduled, but was unable to conduct, an interview with a man who had emigrated from Oaxaca, Mexico, but had lived in Washington County for years. He and his wife were employed at a national fast food chain restaurant. At our initial meeting they spent more than a half hour recounting the numerous instances of discrimination, poor treatment, and abuse they received on the job from both Latino and non-Latino white supervisors and managers. They felt trapped in their jobs, feeling that they could not risk being unable to provide for their children as best they could even as they were aware that higher ups were taking advantage of their precarious situation. They wanted his interview to highlight the difficulties they faced in working and providing for their children. Just before the interview was to be conducted, their son was taken to the hospital for an undisclosed emergency. While I later spoke with the man and heard that his son was out of the hospital and recovering, we were unable to reschedule a time for the interview. While any parent 
may have been too preoccupied for months following the hospitalization of a child to reschedule an interview, it is likely that his hectic work schedule and financial stresses helped to push rescheduling out of the question.

The struggles and stresses of daily life likely discouraged more economically marginalized individuals from participating in this project. Current seasonal migrants, for example, would have been unlikely to attend the micro-business course at the community organization Adelante Mujeres, designed to help Latino residents open their own businesses, through which I made contact with several narrators. Had they been looking to settle in the county, they likely would have been concerned with finding year-round housing and employment before considering investing their time and energies in learning how to operate their own businesses. My contacts did not put me in touch with any current seasonal migrants, people who were, for the most part, focusing their energy on daily survival. The average seasonal migrant has a smaller social network and fewer friendships in Washington County than the year-round resident-another factor decreasing the likelihood that we would be put in touch by a mutual connection.

As related by the narrators, and supported by other primary and secondary sources, the Latino population of the county is not comprised solely of individuals whose personal or ancestral origins can be traced to Mexico. I was unable, however, to interview anyone who had immigrated from Central America or anywhere in Latin America other than Mexico, and the interviews speak only to the experiences of people who were born in Mexico or who trace their family roots there. Narrators 
did speak about other Latinos, and I used their comments and other source materials to offer some limited analysis on the broader Latino population.

\section{Newspaper articles}

As mentioned by Yow, generalizations based off of oral history interviews are not especially strong on their own, and I used a number of newspaper articles to corroborate the trends and facts that narrators shared during their interviews. One of my narrators recommended that I look up court cases where farmworkers had filed suit against owners, managers, and recruiters for unmet promises of wages and working and living conditions. I located articles chronicling several important cases through the online archives for the Oregonian, a newspaper with statewide coverage and distribution. I also found articles that touched on issues of tensions with white residents and police, the themes of assimilation and cultural replenishment, the impact of a growing Spanish-speaking population on the availability of linguistic and culturally-specific services, the tangible benefits provided by mutual aid and social service organizations, and the changing work and educational opportunities for Latinos.

\section{Secondary sources}

A number of works on Latino history in the Pacific Northwest were useful to me in my own research. Erasmo Gamboa outlined the impact of the bracero program that brought single males from Mexico to work in agriculture in Oregon and elsewhere during and after World War II in Mexican Labor and World War II: Braceros in the Pacific Northwest, 1942 - 1947 (1990). Gamboa highlighted the importance of the program for the future of agricultural work in the nation and the 
state of Oregon. Bracero laborers freed up working-class whites from field work to pursue opportunities generated by wartime and postwar prosperity, and made farmers dependent on ethnic Mexican labor. "Mexican Americans from the Southwest would be called up to replace the braceros"12 as farmers sent recruiters to the states bordering Mexico to entice workers north with promises of good wages and living conditions that largely went unfulfilled. Even if they themselves did not return to the United States after the program ended, braceros passed on knowledge of the U.S. communities in which they resided to friends and family members and therefore "functioned as a conduit of Mexican immigrants to many Chicano communities throughout the United States."13 According to Gamboa, bracero labor encouraged farmers to subsequently recruit Latino workers, thereby prompting Mexican Americans and Mexican nationals to relocate to the Pacific Northwest. ${ }^{14}$

Erasmo Gamboa was involved with other published works that highlight the importance of oral history as a medium for researching the histories of ethnic Mexicans in the region. Gamboa and Carolyn M. Buan edited Nosotros The Hispanic People of Oregon: Essays and Recollections (1995). The work combined essays written by Gamboa and other historians and academics with excerpts of interviews from an oral history project coordinated by Gamboa for the Oregon Council for the Humanities (which published the book). Gamboa also edited Voces Hispanas: Excerpts from the Idaho Hispanic Oral History Project (1992), a collection of excerpts

\footnotetext{
12 Erasmo Gamboa, Mexican Labor and World War II: Braceros in the Pacific Northwest, 1942 - 1947 (Seattle: University of Washington Press, 1999), 127. 13 Ibid. 14 Ibid.
} 
produced from the oral histories conducted with the Idaho Hispanic Oral History Project that was published by the Idaho Commission on Hispanic Affairs and the Idaho Humanities Council. This collection focused on the experiences of elderly residents of a number of Idaho towns - similar in a way to Rogers's book that featured interviews with older African American narrators. For my own work, which seeks to place the historical experiences of community members in the context of the massive demographic shifts that have occurred since the 1960s, I interviewed both long-settled residents and younger and more recent arrivals.

Washington County transplants from Texas developed activism and mutual aid infrastructure as their community grew and as they became aware of Chicano Movement developments in the Southwest. Glenn Anthony May's Sonny Montes and Mexican American Activism in Oregon (2011) outlined the ways that ethnic Mexicans and their allies in the Willamette Valley region were influenced by the movement as it developed in California. The book also detailed the history of Mt. Angel's Colegio Cesar Chavez-the higher education institution for Mexican American students with which two Washington County narrators were involved.

Mexicanos in Oregon: Their Stories, Their Lives (2010), by Erlinda GonzalesBerry and Marcela Mendoza, used a mixture of interviews and other primary and secondary sources to provide an overview of both the historical and contemporary experiences of ethnic Mexicans in the state. The authors gave some attention to activism in Washington County and provided an overview of the demographic shifts that occurred in Oregon as more and more Mexican nationals arrived. 
The Chicano Experience in the Northwest (1995), edited by Carlos Maldonado and Gilberto Garcia, is a collection of essays on ethnic Mexicans. In the introduction the editors wrote that the volume was compiled to remedy the lack of a comprehensive volume on the historical and contemporary experiences of ethnic Mexicans in the region. Gilberto Garcia provided a helpful portrait of Chicano activism in the region in his chapter, "Organizational Activity and Political Empowerment: Chicano Politics in the Pacific Northwest." According to Garcia, "the organizational activity for political empowerment focused on the need for socialcultural centers.... The cultural centers served as focal points for the organizational development of the community."15 This assertion highlights the importance of Centro Cultural of Washington County to the county's Chicano activism and to the Latino community for the services the center has provided.

Memory, Community, and Activism: Mexican Migration and Labor in the Pacific Northwest (2005), edited by Jerry Garcia and Gilberto Garcia (the same Gilberto Garcia who was an editor for the previous volume), served to follow up and complement The Chicano Experience in the Pacific Northwest. According to the editors, this volume did more to address "immigration, popular culture, comparative race relations, and religion"16 than the Maldonado and Garcia volume. In the

\footnotetext{
15 Gilberto Garcia, "Organizational Activity and Political Empowerment: Chicano Politics in the Pacific Northwest," in The Chicano Experience in the Northwest, edited by Carlos S. Maldonado and Gilberto Garcia (Dubuque, Iowa: 1995), 74. 16 Jerry Garcia, Gilberto Garcia, eds. Memory, Community, and Activism: Mexican Migration and Labor in the Pacific Northwest (East Lansing, Mich.: Julian Samora Research Institute, 2005), 19.
} 
introduction, Jerry Garcia offered some explanations for the relative paucity of scholarship on ethnic Mexicans in the Pacific Northwest:

First, the Eurocentric perspective of the Pacific Northwest history has monopolized and marginalized the voices of the "other" or those ethnic groups considered marginal or unimportant to the region's history, such as Mexicans. Second, the field of Chicana/o Studies continues to use the Southwest paradigm as its modus operandi in explaining the Chicano experience for all people of Mexican ancestry in the United States.... Chicana/o scholars continue to emphasize the sacredness of the Southwest. ${ }^{17}$

In the chapter "Past, Present, and Future Directions: Chicana/o Studies Research in the Pacific Northwest," Gilberto Garcia helpfully outlined the work of those individuals-Tomas Ybarra-Fausto, Antonia Castañeda, Carlos B. Gil, Ybonne Yarboro-Bejerano, Richard Slatta, and Erasmo Gamboa-who completed early scholarship on Chicano history in the region. Garcia also mentioned the publication of community-focused studies, including Carlos Maldonado's "Mexicanos in Spokane, 1932 - 1992" (published in Revista Apple in 1992), co-editor Jerry Garcia's “A Chicana in Northern Aztlan: An Oral History of Dora Sanchez Treviño" (published in Frontiers in 1998) that looked at gender and labor migration issues in the community of Quincy, Washington, and Gilberto Garcia's own “Mexicano Communities in the State of Washington: The Case of Othello, Washington" (published in the 2002 volume The Illusion of Borders : the National Presence of Mexicanos in the United States).

${ }^{17}$ Jerry Garcia, “Introduction," in ibid, 15 - 16. 
Richard Slatta, who completed his MA thesis, “Chicanos in Oregon: A Historical Overview," at Portland State University in 1974, later published several articles on ethnic Mexicans. “Chicanos in the Northwest: An Historical Overview of Oregon's Chicanos" appeared in the fall 1975 issue of Aztlán: A Journal of Chicano Studies. The article provided a brief historical overview of ethnic Mexicans in Oregon and an overview of the Chicano Movement in the state and the ways that ethnic Mexicans were honoring their culture and creating community through communication mediums. "Source materials ... are limited, but local archives and newspapers, state and federal records, and interviews with long-time residents should bear fruit," he wrote. "The sources exist, the need exists; the field is open."18

Slatta's article "Chicanos in the Pacific Northwest: A Demographic and Socioeconomic Portrait" was featured in the October 1979 issue of The Pacific Northwest Quarterly. He used data from the 1970 census to sketch a demographic portrait of ethnic Mexicans and the problems they faced in Washington and Oregon. "Festejando Community: Celebrating Fiesta Mexicana in Woodburn, Oregon," by Elizabeth Flores, an associate professor in humanities at Grand Canyon University and researcher of literary, cultural, and gender studies, was featured in the volume Chicanas and Chicanos in Contemporary Society (2004), edited by Roberto De Anda. In the article, Flores assessed the ways that Woodburn's annual celebration for ethnic Mexican residents had changed between its inception in 1966 and the early 2000s. Flores noted the shift of music and activity choices over the

18 Richard W. Slatta, "Chicanos in the Pacific Northwest: An Historical Overview of Oregon's Chicanos," Aztlan: A Journal of Chicano Studies 6 (1975): 327 - 340, quote on 336. 
years: from baseball and Tex Mex music favored by tejanos to mariachi and banda music and soccer favored by Mexican immigrants as these immigrants came to outnumber the early settling tejanos. Demographic changes of the Latino population-as reflected by changes to the Fiesta Mexicana—occurred in largely the same ways in Woodburn as in Washington County. Flores's examination of the celebration aided my efforts to conceptualize cultural change and adaptation in Washington County.

Many of the authors and editors of the above-mentioned works commented on the relative paucity of research on Mexicans and other Latinos in the Pacific Northwest. In order to understand the conditions elsewhere that prompted their relocations and in order to better analyze their social and economic histories in Washington County, I looked to a number of sources that examined Latino experiences in other parts of the nation.

Marc Rodriguez's The Tejano Diaspora (2011) detailed the economic and social conditions that prompted Mexican American tejanos to leave Texas in the mid-twentieth century to seek opportunities elsewhere in the nation. His work specifically examined the political activity of tejanos in Crystal City, Texas, and in their adopted homes in Wisconsin and of the networking and information that passed between the two locations as people moved back and forth. Rodriguez's examination of how school administrators and faculty perpetuated inequality and discrimination against ethnic Mexican students helped contextualize narrator Evangelina Sanchez's recollections of her social and educational experiences in 
Texas. Rodriguez's descriptions of forces of discrimination and intimidation in Texas support narrator recollections that rationalized relocating outside of the state.

Ethnic Mexicans in Crystal City, Texas, achieved singular success in winning school board positions and in electing candidates to all five city council seats during the 1963 elections. The narrators interviewed for this project relocated from other communities in Texas where ethnic Mexicans did not experience levels of success within the political system comparable to that of Crystal City residents. They did not participate in a two-way stream of knowledge-sharing as occurred between tejanos in Crystal City and in Wisconsin. Washington County narrators were from different localities in Texas. They formed community after settling in Oregon.

In different decades and regions of the United States, Mexican Americans struggled with how to respond to new arrivals from Mexico. In addition to examining the history of Mexican Americans and the social pressures they faced in California and Texas in the early and mid-twentieth century, David Gutiérrez's Walls and Mirrors: Mexican Americans, Mexican Immigrants, and the Politics of Nationality (1995) explored "the almost comical love-hate relationships between U.S.-born Mexican Americans and more recent immigrants from Mexico."19 Gutiérrez's examinations of reasons for both intra-ethnic tension and calls for ethnic solidarity were useful in evaluating the specific ways that these groups interacted with one another in Washington County.

\footnotetext{
19 David Gutiérrez, Walls and Mirrors: Mexican American, Mexican Immigrants, and
} the Politics of Ethnicity (Berkeley: University of California Press, 1995), 2. 
Armando C. Alonzo's Tejano Legacy: Ranchers and Settlers in South Texas, 1734 - 1900 (1998) explored how South Texas became a "Tejano Homeland" as, in contrast with border regions in other states bordering Mexico, ethnic Mexicans maintained their numerical superiority and largely preserved Mexican culture through 1900. Alonzo's portrait of the region in the late nineteenth century was helpful in better understanding the region where tejano narrators resided before relocating to Oregon.

Neil Foley's The White Scourge: Mexicans, Blacks, and Poor Whites in Texas Cotton Culture (1999) charted the creation of a tri-ethnic agricultural labor force in Central Texas in the early decades of the twentieth century. Foley analyzed the racialized ideas held by white farm owners that generally portrayed ethnic Mexicans as preferable workers-a belief that helped motivate farm owners to recruit workers directly from Mexico. The racialized ideas of Texas farm owners, and the long-term patterns of labor migration from Mexico that such recruitment efforts encouraged, shaped Oregon's seasonal agricultural labor force and its relations with farm owners in later decades.

In Occupied America: A History of Chicanos (2010), Rodolfo F. Acuña wrote of Texas as a "reserve labor pool" for the Midwest beginning in the 1920s. ${ }^{20}$ Acuña noted only small numbers of ethnic Mexicans in Oregon and other Northwest states in the 1920s. After World War II, though, tejanos and then other groups of ethnic

${ }^{20}$ Rodolfo F. Acuña, Occupied America: A History of Chicanos (Boston: Pearson, 2011), 171. 
Mexicans would become critical to agricultural labor in the Northwest as they had in the Midwest decades earlier.

Guadalupe Friaz wrote, in an article in Maldonado and Garcia's 1995 volume The Chicano Experience in the Northwest, that scholarship on Latinos in the Northwest was lacking in comparison to the Midwest. ${ }^{21}$ Scholarship on Midwestern Latinos was helpful in seeking to understand the experiences of Latino people in Washington County. Several works focusing on Latinos in the Midwest-where, according to David A. Badillo in Latinos in Michigan (2003), they were responsible for more than half of the region's population growth between 1990 and 2000offered up important points of comparison and contrast in attempting to better understand the growth of this population in Washington County.

Apple Pie and Enchiladas: Latino Newcomers in the Rural Midwest (2004), edited by Ann V. Millard and Jorge Chapa, examined discrimination and other struggles that Latinos faced in rural Midwestern communities, as opposed to urban areas like Chicago or Detroit where industrial jobs had long attracted Latinos. Catalina Burillo and Ann V. Millard's chapter, "The Battle for Chapita Hills," detailed the eventually successful struggle to create low-income housing apartments in Shelby, Michigan, against bitter opposition from white residents from 1981 to 1983. Opposition to Chapita Hills in Michigan paralleled the fierce resistance to migrant housing mounted by white residents in the Washington County communities of Forest Grove and Hillsboro in the early 1980s. The research team responsible for

${ }^{21}$ Friaz, "A Demographic Profile of Chicanos in the Pacific Northwest," in The Chicano Experience in the Northwest, 37. 
the book completed a number of interviews with both Latino and non-Latino white residents, further highlighting the importance of speaking directly with subjectswhether through oral history interviews or interviews on contemporary issueswhen studying a marginalized group.

Latin American Migrations to the U.S. Heartland: Changing Social Landscapes in Middle America (2013), edited by Linda Allegro and Andrew Grant Wood, is focused on Nebraska, Kansas, Oklahoma, Iowa, Missouri, and Arkansas. Miranda Cady Hallet's chapter, “Rooted/Uprooted: Place, Policy, and Salvadoran Transnational Identities in Rural Arkansas," explored how migrants constructed transnational identities, and commented on tension between Salvadorans and Mexicans in the town of Danville. These examinations of identity and intra-ethnic tension helped me to better conceptualize and contextualize these issues as they related to Latinos in Washington County.

La Causa: Civil Rights, Social Justice, and the Struggle for Equality in the Midwest (2004), edited by Gilberto Cardenas, covered the involvement of Midwestern Latinos in social movements to advocate for equal rights and fair treatment. As characterized by Ricardo Parra in his chapter "Latinos in the Midwest: Civil Rights and Community Organization," the Great Lakes region of the Midwest offered industrial labor and unionizing opportunities mostly absent in Washington County and the Northwest, where Latinos arrived largely for agricultural work. In both Midwestern communities and in Washington County, Latinos were influenced by the developments of the Chicano Movement in the Southwest even as they 
tailored its momentum to local conditions with respect to the size of Latino populations and to prevailing political and social climates.

The Maya of Morganton: Work and Community in the Nuevo New South (2003), by labor historian Leon Fink, focused on the rise of a Guatemalan community in Morganton, North Carolina, in the 1990s and early 2000s, a development prompted by employment opportunities at a poultry processing plant. Fink's treatment of the reasons that prompted Guatemalans to emigrate, of the recruitment and referral networks that brought many Guatemalans to Morganton, and of the ways that these immigrants formed community with other immigrant and resident Latinos was helpful to my examination of a growing and diversifying Latino population in Washington County.

In Mexican Americans Across Generations: Immigrant Families, Racial Realities (2011), sociologist Jessica M. Vasquez examined cultural identity and adaptation across three generations of multiple ethnic Mexican families in southern and northern California. Her analysis and findings highlighted important points of consideration for contemplating change among the Latino population of Washington County since the 1960s and the different opportunities presented to different generations of narrators' family members.

\section{Structure of work}

This work is broken down into three chapters along thematic and chronological lines. Chapter I explores how and why a small number of families, almost entirely from Texas, settled in Washington County in the 1960s. After providing a short overview of the bracero program that, as described by Erasmo 
Gamboa, made Oregon farmers dependent on ethnic Mexican labor, the chapter addresses why tejano families left Texas seasonally for work, how they were recruited or otherwise arrived in Oregon, and why families decided to stay. Interview excerpts describe living conditions and the work and educational experiences of narrators in Washington County, as well as the discrimination they faced. The narrators explain the formation of the small, tight-knit community and the mutual aid infrastructure that these families created to help both migrants and year-round residents. The work of this community and their allies was augmented in the late 1960s and early 1970s by state and federal funding for programs to benefit ethnic Mexicans.

The influence of the Chicano Movement as it developed in California and the Southwest had an impact on activism in Oregon and Washington County. It encouraged the creation of Colegio Cesar Chavez. Though located outside of the county in Mt. Angel, Colegio Cesar Chavez, the first accredited higher education institution that addressed the academic, social, and linguistic needs of Mexican Americans, directly affected the work and educational opportunities for two narrators and had an impact on higher educational opportunities in the state that long outlasted its dates of operation.

Farm workers and community allies began to formally challenge employer abuses at the end of the 1960s. The community established Centro Cultural of Washington County and the Virginia García Memorial Health Center. These organizations weathered federal defunding and the wane of activist fervor and, as of 2014, continued to provide necessary services to the Latino population. Chapter I 
features excerpts of interviews with narrators Hector Hinojosa, Evangelina Sanchez, and Enedelia Hernandez Schofield.

Chapter II explores the economic and social pressures that brought Mexican nationals and other Latinos, rather than Mexican Americans, to Washington County for seasonal work and to then settle permanently in the 1970s and 1980s. A growing Latino population offered new work and career opportunities to tejanos in the county to serve as cultural and linguistic brokers for new arrivals. This chapter examines the responses of both tejano and Mexican immigrant narrators and Sister Ina Marie Nosack, who worked with migrant families, to explore different perspectives on the roots of intra-ethnic tension and the ways that decades of heavy incoming migration and settlement affected community cohesion. As I was unable to speak with narrators who relocated during the 1970s and 1980s, this chapter utilizes secondary sources, as well as comparisons with the narratives of interviewees who relocated in subsequent decades, in order to examine changing migration patterns and the issues confronting both new migrants and settled Latinos in these decades.

People like Emilio and Hortencia Hernandez, with their work at Centro Cultural and elsewhere, combated tensions and welcomed newcomers in working toward the creation of a broader Spanish-speaking community. Chapter II also examines ongoing labor struggles and court cases that exemplify the persistence of employer abuse as the seasonal labor force became overwhelmingly comprised of migrants from other countries. Nosack recalled work to reach out to migrant families and build relationships between non-Latinos and Latino migrants. The late 
1980s witnessed new opportunities for residency for many current or former migrants with the Immigration Reform and Control Act (IRCA) of 1986. This chapter includes excerpts from interviews with narrators Sister Ina Marie Nosack, Evangelina Sanchez, Enedelia Hernandez Schofield, Laura Gamboa, and Arturo Villaseñor.

Chapter III begins by analyzing the ways that the IRCA and the North American Free Trade Agreement (NAFTA) encouraged both short term and long term increases in migration from Mexico. This chapter looks at the lives of the Mexican immigrant narrators in Mexico, their relocation experiences in the 1990s and 2000s, and their lives in Washington County. These narrators-like the tejano settlers-were drawn to Washington County in search of better prospects for themselves and their families, but came from a variety of formal education backgrounds in Mexico and realized different opportunities for themselves in Oregon. This chapter explores the work, educational, and social experiences of these narrators. It compares their responses to those of the tejanos to show how a variety of changing conditions and factors, including the mutual aid infrastructure created by the first settled families, changed opportunities for new waves of Spanishspeaking immigrants.

Chapter III also explores the expanding diversity of the community during these decades, as more migrants arrived from different socioeconomic backgrounds and geographically distant home communities in Latin America. As happened elsewhere in Oregon, indigenous migrants from Mexico and Central America arrived 
in considerable numbers. Many of these individuals spoke Spanish as a second language or did not speak it at all.

This chapter examines how, as the Latino population became increasingly culturally diverse, the legacy of mutual aid and welcoming newcomers continued to aid recent arrivals and the disadvantaged. Ongoing Latino immigration aided in the process of cultural replenishment. The importance of such replenishment is highlighted by narrator assertions of the ways that language and culture are fundamentally tied to their identities.

For the most part, narrators seemed eager to share their struggles, successes, and assessments of culture and community with me. Some were especially interested in promoting cross-cultural understanding, and they hoped that a Latino and non-Latino public would be able to access the interviews through the museum to better understand these personal and community histories. One narrator concluded an email stating: "Espero, asimismo ayudar aunque sea con un grano de arena a comprender y comprendernos más los unos a otros-I hope, also, to help even though it may be with [as small as] a grain of sand in understanding each other from one group to the other."22

${ }^{22}$ Giores, email to author. November 6, 2013. 
Figure 1: Map of Washington County, Oregon

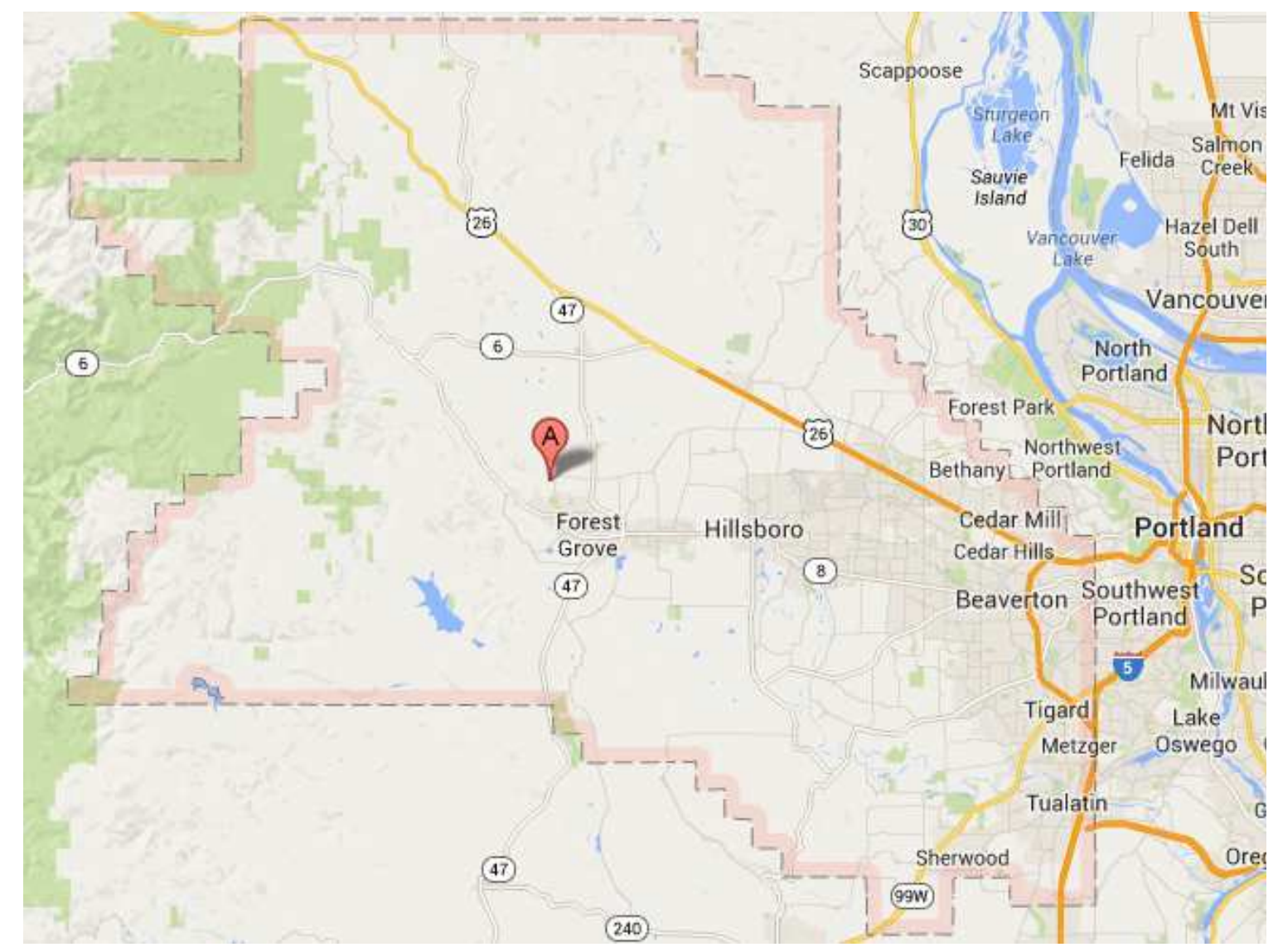

The city of Cornelius is between Forest Grove and Hillsboro, and the community of Aloha is between Hillsboro and Beaverton off of Highway 8. The city center of North Plains is located almost directly north of Hillsboro, just north of Highway 26. Map used in accordance with Google Maps' fair use policy. 


\section{Chapter I Tejanos and Community Formation in the 1960s and 1970s}

\section{Narrators introduced in this chapter:}

- Hector Hinojosa was born in Matamoros, Tamaulipas, Mexico, and grew up in Harlingen, Texas. He first came to Oregon from California with his parents and siblings. The family settled permanently in Oregon in 1962 (before starting his fourth-grade year of school). Hector was living in Hillsboro at the time of the interview.

- Evangelina Sanchez was born in Needville, Texas, and spent the first nineteen years of her life in Texas. She moved across the country seasonally with her family for work for several years. She relocated to Washington County in 1967 with her children, her mother, and her siblings. Evangelina was living in Hillsboro at the time of the interview.

- Enedelia Hernandez Schofield was born in McAllen, Texas, in 1958 and moved to Washington County from California in 1962 with her parents, Emilio and Hortencia "Tencha" Hernandez, and her siblings. At the time of the interview, she was the principal of Butternut Creek Elementary School in Aloha.

This chapter summarizes the events that introduced farm owners and operators in Washington County to ethnic Mexican labor and made them dependent upon these people to complete seasonal farm work. Northwestern farmers recruited laborers from Texas and the states of the Southwest; recruitment efforts were largely responsible for bringing ethnic Mexicans to Washington County. A variety of factors prompted a small number of tejano families to settle permanently in the county in the 1960s. They began to form community and mutual assistance networks to honor their culture, protect themselves from discrimination, and further their economic opportunities. Influenced by the Chicano Movement on a regional and national level beginning in the late 1960s, leaders and activists advanced their efforts to build community and create opportunities for new arrivals 
and settled families alike. The tejano narrators featured in this chapter were able to further their educational and career paths while assisting subsequent immigrants and other Latinos.

Washington County, situated just east of Portland's Multnomah County, experienced a dramatic increase in general population during the late twentieth century and first decade of the twenty-first century. The population jumped from 159,370 in 1970 to 531,610 in 2010.23 This impressive rate of growth has been outpaced by the specific rates of population increase of the Latino population from roughly 2,540 in 1970 to 83,810 in $2010 .{ }^{24}$ Arrivals in recent decades have come largely from the many states of Mexico, but a considerable number of these immigrants have relocated from other countries across Latin America.

The current Latino population of the county can be traced back to a much smaller and more homogenous group. A tightly knit community of families, almost exclusively from Texas, ${ }^{25}$ emerged in the 1960s as individual families transitioned from seasonal migration to permanent residence in the county. Emboldened in part by the Chicano Movement in the late 1960s and 1970s, members of these families (with the help of some important non-Mexican allies) established important aid and cultural organizations and undertook various strategies to protect their

23 "Population in the U.S.," U.S. Census Bureau, accessed February 21, 2014. 242013 State Profile Oregon: State and County Projections to 2040, Woods \& Poole Economics, 358.

25 Some families from New Mexico, or who had spent years in New Mexico, came to Oregon in the late 1960s and 1970s for reasons similar to those of the families from Texas. See Amie Thurber, "The History of the Latino People of Washington County: Weaving Community" (unpublished paper for Masters of Education Program: University of Montana, 2012). 
fundamental legal and human rights. These actions, coupled with Oregon's absence of historically entrenched segregation between Mexicans and whites which long characterized race relations in Texas and the Southwest, created a comparatively favorable atmosphere for settlement and expanded work and educational opportunities for settled families and new arrivals alike.

\section{The bracero program and seasonal farm labor}

A documented community, small as it was in the beginning, is traced to the mid-1960s, but ethnic Mexicans worked and resided in the county two decades prior. The bracero program, the name commonly used to refer to the Mexican Farm Labor Program, brought men from Mexico to the county in 1942 to fill the labor shortage caused by World War II. The program, the result of an agreement between the U.S. and Mexican governments, allowed for able-bodied Mexican men to work in agriculture and some other industries in various states throughout the United States. Some states continued to participate in the program into the 1960s, but the states of the Northwest—reacting against strike activity from bracero workers and the high costs of transporting workers-ended participation in the program in 1947.26

Erasmo Gamboa argued that World War II created the conditions that eventually led to a pattern of seasonal migration to Oregon and the Pacific Northwest for Mexican American families. The war pushed many rural workingclass whites out of fieldwork and into the armed forces or new defense industry jobs. The relative prosperity and employment opportunities of the postwar decades kept them from returning to the fields. The bracero program offered a replacement

26 Erasmo Gamboa, Mexican Labor and World War II, 123. 
source of labor for farm owners of Washington County and other counties across the Pacific Northwest. ${ }^{27}$

Mexican braceros ensured that the crops did not go unpicked. The men were not allowed to remain in Oregon in the months between consecutive seasons for which they were contracted, and they were not permitted to stay after Oregon ceased to participate in the program in 1947. Some former braceros did, however, return to Oregon after the program ended. Ruben Contreras spent the summers of 1944 and 1945 working as a bracero-first in agriculture in the Midwest and then repairing tracks for the Southern Pacific Railroad in Oregon. From a prominent Mexican family, Contreras was prompted by curiosity and a sense of adventure, rather than economic necessity, to work as a bracero. In the months between the end of his contracted work with the railroad and the deadline by which he had to return to Mexico, he relocated to Yamhill County's McMinnville to work seasonally in agriculture. He returned to McMinnville from Mexico in 1947; the following year he married Alberta Schmauder, a woman he had met while in McMinnville in 1945. The couple stayed in McMinnville and raised a family. ${ }^{28}$

Other labor demands of the wartime economy brought a small number of ethnic Mexicans to the state. The family of Joseph Gallegos, who in early 2013 became the first Washington County Latino to serve in the Oregon State Legislature, relocated to Oregon from San Antonio, Texas, during World War II in hopes of

27 Glenn Anthony May, Sonny Montes and Mexican American Activism in Oregon (Corvallis: Oregon State University Press, 2011), 33.

28 May, Sonny Montes, 36. 
finding work at Portland's shipyards. ${ }^{29}$ Mike Flores's family arrived in Portland in search of the same opportunities in $1944 . .^{30}$ Other ethnic Mexican families may have relocated in or near Washington County for similar wartime opportunities, and former braceros may have returned to Washington County permanently or seasonally after departing for Mexico at the expiration of their contracted labor period.

Strike activity and protests from braceros in the region-over unpaid wages, hazardous work conditions, and other forms of poor treatment and discrimination-combined with increasing costs of program participation to encourage farm owners to push for the termination of the bracero program in the Pacific Northwest. They turned to new sources of ethnic Mexican labor. ${ }^{31}$ Northwest farmers began to actively recruit in Texas and in other states bordering Mexico with large Mexican American populations. Hoping to avoid labor disputes and challenges like those experienced with braceros, farm owners sought to recruit whole families. The braceros had been either single men or men temporarily living away from their families in Mexico. Many farm owners and operators believed that whole families, concerned with the daily survival of their younger and more vulnerable members, would be less likely than unaccompanied men to challenge the conditions and treatment they experienced. The families worked and resided for several months of the year at camps established by farmers on their properties. Oregon farm owners

${ }^{29}$ May, Sonny Montes, 182. Gallegos was elected as the representative for district 30, which includes Hillsboro and North Plains, to the state legislature. 30 "Mexican-American Men Say Their People Give Full Value," Oregonian, June 13, 1976, 55.

31 Erasmo Gamboa, Mexican Labor and World War II, 38 - 39, 88, 126 - 127. 
used their political and economic clout to curtail legal forms of labor organizing and protest, persuading the state legislature to pass a law that severely limited the legal right to picket farms in 1961. Some of the owners resorted to extralegal means to recruit and maintain workers. ${ }^{32}$

Racism in Oregon operated differently against different minority groups. White farm workers still made up a considerable (but declining) proportion of the workforce in the middle of the twentieth century; their prejudices may have made ethnic Mexican laborers comparatively preferable for Oregon farm owners. In an article from the Oregonian from 1952, John B. Hounsell, a Hood River orchardist and state representative, said that if growers were to "hire negro help the white help will move out of the camps."33 According to Hounsell, "Mexican help is a better class of help than many of the migrants because they are saving their money." ${ }^{34}$ In the midtwentieth century, as ethnic Mexicans comprised more and more of the seasonal agricultural labor force in Oregon in comparison with white migrants, many of those who pondered labor issues were inclined to assign inherent traits such as industriousness and thrift to workers grouped along lines of class and ethnicity.

Similar language that stereotyped ethnic Mexicans as good workers had been used in previous decades in other parts of the United States. Neil Foley's The White Scourge examined the economic and social positions of white, black, and Mexican

32 Erlinda Gonzales-Berry and Marcela Mendoza. Mexicanos in Oregon: Their Stories, Their Lives (Corvallis: Oregon State University Press, 2010), 62 - 65. On picket law, see also Harold Hughes, "Senate Votes to Restrict Farm Picketing," Oregonian, April 26, 1961, 9.

33 Fred G. Taylor, “Official's Story of Migrants Draws Challenge by Solon,” Oregonian, October 1, 1952, 12.

34 Ibid. 
agricultural workers in late nineteenth and early twentieth-century Central Texas.

Poor white tenant farmers and sharecroppers there increasingly came to be viewed as "defective" and "lazy" due in part to their inability to succeed financially in a society that deemed them socially superior to other ethnic groups in a strict racial hierarchy. Influenced by rhetoric that echoed Hounsell in calling ethnic Mexicans a "better class of help," Texas farm owners increasingly replaced white sharecroppers and tenants with ethnic Mexican sharecroppers in the early decades of the twentieth century. Due to the racial hierarchy that prevailed in Texas, black and Mexican workers were less likely to agitate for better pay and living conditions than white sharecroppers and tenants. Farmers sought to cast their hiring preferences as a reflection of the moral character of the workers by ethnicity, rather than by the advantages they gained by hiring more vulnerable workers: "By 1915 landowners throughout Central Texas complained about a new generation of thriftless and unreliable white tenants and sought to replace them with 'active, energetic, honest, and industrious' Mexicans and African Americans." Foley cited an unpublished report on labor in Texas and Oklahoma from the early twentieth century that claimed, "Mexicans are more tractable than either negroes or whites."35

35 Neil Foley, The White Scourge: Mexicans, Blacks, and Poor Whites in Texas Cotton Culture (Berkeley: University of California Press, 1998), 5, 38 - 39. In interviews with Midwesterners in the early 2000s, Ann V. Millard, Jorge Chapa, and the rest of their research team noted that many white interviewees voiced stereotypes of ethnic Mexicans as compliant and hardworking laborers. These responses suggest the persistence of such ethnic stereotypes across more than a century and its spread across much of the United States. See Ann V. Millard and Jorge Chapa, Apple Pie \& Enchiladas: Latino Newcomers in the Rural Midwest (Austin: University of Texas Press, 2004), 119. 


\section{Life for tejano families in Texas}

One important consideration for migration from Texas, the first home of most of the early settling ethnic Mexican families of Washington County, was the change created by the large-scale immigration of Mexicans into that state. Indeed, while the three narrators involved in this project were raised in Texas and identified with tejano culture, they all had direct personal or familial ties to Mexico. Hector Hinojosa was born in Matamoros, Tamaulipas, Mexico, moving across the border at age two with his family to the nearby city of Harlingen, Texas. Evangelina Sanchez was born in Needville, south of Houston, but her mother was born in Zacatecas, Mexico, and her father was born in Guadalajara, Jalisco, Mexico. ${ }^{36}$ Enedelia Hernandez Schofield's mother, Hortencia Hernandez, was born in Reynosa, Tamaulipas, Mexico, and raised in McAllen, Texas, by her aunts. Her father, Emilio Hernandez, was born in McAllen, Texas, but spent four years playing baseball in Mexico as a young man, helping him to forget some of the English he had been taught in Texas schools. According to Hernandez Schofield, community extended across the border in the early and mid-twentieth century:

McAllen is right on the border, so living in Mexico and the Reynosa area I don't think that was its own community as a community together. Not like now where it's very, you know you have to have

\footnotetext{
36 Oral history interview with Evangelina Sanchez, August 2, 2013, Hillsboro, Oreg., in author's possession and in the possession of the Washington County Museum.
} 
your passport to go to Mexico and it's a tighter boundary. The border at that time was very open. ${ }^{37}$

Arriving Mexican nationals created a labor surplus in Texas by the early 1950s. Mexican immigrants to Texas generally lacked effective legal recourse to combat employer abuses and, due to the desperate economic straits that prompted them to relocate from Mexico, were willing to work in agriculture or other unskilled positions for extremely low wages. Conditions continued to worsen as more and more people moved north across the border. Facing declining wages, the loss of jobs, and the inability to effectively organize for better working conditions due to the surplus labor supply, many tejanos, both those who had lived in Texas for generations and those who had moved from Mexico in their own lifetimes, looked to other states for work opportunities. ${ }^{38}$

Some historians of Mexican Americans have singled out Texas as a state known for exceptionally poor treatment of ethnic Mexicans. Poor treatment was another important factor in motivating tejanos to look for opportunities outside of the state. According to David Gutiérrez, from the mid-nineteenth century onward racial animosity developed to a greater and more severe degree in Texas than in California, the other state that witnessed initial heavy immigration from Mexico. Relations between whites and ethnic Mexicans developed along a path characterized by severe racism and by both formal and informal segregation. The Texas Rangers, a state law enforcement agency, terrorized ethnic Mexicans through

37 Oral history interview with Enedelia Hernandez Schofield, August 28, 2013, Portland, Oreg., in author's possession and in the possession of the Washington County Museum.

${ }^{38}$ Gonzales-Berry and Mendoza, Mexicanos in Oregon, 54. 
threatened and realized acts of physical violence to discourage them from challenging the white-dominated hierarchy of power. ${ }^{39}$ In The Tejano Diaspora, Marc Rodriguez's recounting of the history of Crystal City exemplifies the persistence of segregation and Ranger intimidation in early 1960 s south Texas. ${ }^{40}$

"The KKK is alive and well in Texas," 41 Evangelina Sanchez said, with hardened laughter, reflecting on the first nineteen years of her life there. While the high school she attended was not segregated like many in the border region, Mexican-ancestry students at her school were often singled out for abuse by white teachers and students. As punishment for breaking a rule, ethnic Mexican males were sometimes made to run through a belt line, where members of the whitedominated football team would whip them. "Teachers would wear big rings and hit the kids and a lot of our guys on the head." 42 Mexican-ancestry students were made to feel that they were not welcome members of the school-affiliated community: “Even though you might go because it's a school function or whatever, you know you don't belong there. They don't make you feel like you belong there."43

Hector Hinojosa was much younger than Sanchez when he left Texas, having just finished the second grade, and was therefore not as aware of the ways discrimination was operating against him, but he did recall being kicked out of a

${ }^{39}$ Gutiérrez, Walls and Mirrors, 26.

40 Marc Rodriguez, The Tejano Diaspora: Mexican Americanism and Ethnic Politics in Texas and Wisconsin (Chapel Hill: The University of North Carolina Press, 2011), 22, 53. For more on conditions in Texas, see Gonzales-Berry and Mendoza, Mexicanos in Oregon, $62-65$.

41 Sanchez interview, August 2, 2013

42 Ibid.

43 Ibid. 
store with his brothers on the grounds of their ethnicity. ${ }^{44}$ Emilio Hernandez remembered that he had to be careful when travelling across Texas, as gas stations in some areas would refuse to do business with ethnic Mexicans: "We had to take chances to go from El Campo to La Victoria to get some gas up there. And we take chances, that we might not get gas up there either. La Mesa, Texas, was the same way."45

Marc Rodriguez's Tejano Diaspora focused on specific connections between Wisconsin and Crystal City, Texas, but he noted the broader trends that prompted tejanos to migrate and settle everywhere from the Great Lakes states of the Midwest to California and the Pacific Northwest. "It was in the North that migrants experienced greater freedom and flexibility - a fact that reinvigorated the migrant stream as Tejanos increasingly moved north and west in search of opportunity." 46

\section{"Roaming around looking for work"}

Tejano narrators featured in this project did not come directly to Oregon from Texas. When they did first come to Oregon, some regarded it as another temporary place of residence, a stop on the "migrant stream" that pulled them across the nation for work. Hector Hinojosa's family spent a year in California before relocating to Hillsboro. Most tejanos relocated to states in the North and West; the few families that relocated to states in the Southeast struggled with strict racial hierarchies and faced uncertainties regarding their own status in a society defined

\footnotetext{
${ }^{44}$ Oral history interview with Hector Hinojosa, July 29, 2013, Hillsboro, Oreg., in author's possession and in possession of the Washington County Museum. 45 Emilio Hernandez, oral history interview with Michael O’Rourke (Hillsboro, Oreg., March 22, 2000). Transcription in possession of the Washington County Museum. 46 Rodriguez, The Tejano Diaspora, 158 - 159.
} 
by a white-black racial binary. After returning from Europe in 1947 following his service in the army during and after World War II, Emilio Hernandez and his new wife Hortencia relocated from Texas to Clarksdale, Mississippi to work for several years as sharecroppers. The couple gave birth to their first daughter there, but left Mississippi due to social relations in the community. Hernandez recalled African American sharecroppers being cheated and underpaid by farm owners, and African American women being sexually exploited or violated by white residents. "We had to pull out from up there because I didn't like the actions of the people." 47 In her 2000 interview with Michael O’Rourke, Enedelia Hernandez Schofield said “I sometimes hear my father talk about when he was in Mississippi ... no blacks were allowed in certain restaurants and how sometime[s] he had to look at the people and say 'Are they going to see me as a black person or are they going to see me as a white person because I'm Hispanic[?]'"48 The Hernandez returned to Texas.

Julian Ruiz, a tejano born in 1930 who eventually relocated to Oregon and worked as a labor contractor in the Willamette Valley's Marion County and surrounding areas, spent seasons sharecropping with his family in Louisiana from 1942 to 1946. He shared his story in Garcia and Garcia's volume Memory, Community, and Activism. Eight of the twenty families where they worked as sharecroppers were tejano-the rest were black. While Ruiz remembered relations between black and tejano families as friendly, the tejanos were warned by the sheriff

\footnotetext{
47 Emilio Hernandez interview with Michael O'Rourke, March 22, 2000.

48 Enedelia Hernandez Schofield, oral history interview by Michael O'Rourke (Hillsboro, Oreg., March 22, 2000). Transcription in possession of the Washington County Museum.
} 
and white residents against socializing with the black population. At the movie theater, "we were allowed to sit in the main floor but the Americanos would at times threaten to put us in the balcony if we mixed with the blacks." ${ }^{49}$ Unlike in many parts of South and West Texas, ethnic Mexicans in this Louisiana community were not being strictly segregated from whites in the 1940s; instead, they were offered a qualified and conditional inclusion into white society on the grounds that they reinforce the existing system of white-black segregation. Ruiz, like Hernandez, reacted negatively to the social/racial hierarchy he witnessed in the Deep South.

Several years after leaving Mississippi for good, the Hernandez family went to Fresno, California, to work and visit Emilio's sister. While there, Emilio met Ike Iwasaki, a Japanese American owner of a farm and nursery in Hillsboro in Washington County. Iwasaki offered the family seasonal work and encouraged Emilio to consider relocating permanently to the county. Emilio decided to do so, and the family left California for Oregon..$^{50}$

Evangelina Sanchez's family began migrating after her mother married her stepfather, a man who had previously migrated to Indiana and the Detroit area. With her mother, stepfather, siblings, and children, Sanchez migrated to various states. She remembered following another family to Pasco, California, and living in a migrant camp there:

We even worked in Colorado for a few years and moved back and forth. It was interesting but it was like roaming around looking for

49 "Testimonio de un Tejano en Oregon: Contratista, Julian Ruiz," in Memory, Community, and Activism, 213.

50 May, Sonny Montes, 36. 
work wherever there was work. And when there wasn't work many times it was like he would work or we would look for part-time work in order to survive, wherever we could find it. ${ }^{51}$

Sanchez recalled working a variety of jobs to make ends meet during those times: "I eventually actually worked at a rose packing plant. They would pack the roses that they cut and tie them with strings and everything and label them .... But mostly I was working the fields. I also worked at a shoe factory." 52

\section{"If you're sick you're still out there and picking as much as you could"}

The recruitment efforts of Oregon farm owners and managers in Texas and the Southwest were largely responsible for attracting seasonal labor. The reality that these families discovered upon arrival often did not match the promises that the owners and recruiters had made. Sanchez, who first migrated seasonally to Washington County for work (and later settled permanently in 1967), spoke about the disappointment and poor living conditions that her family discovered upon arrival:

In Oregon, the propaganda when the farmers go to Texas is you've got washing machines, you've got toilets, you've got beautiful cabins, the scenery and everything. And we got here and it was one room. One room and it has to be about the size of this kitchen [approximately twenty feet by twelve feet] .... You have a stove in the corner and you have two bunk beds over on the other corner and you have toilets also that you have to go out and walk. And the washing machines were of course the ringer washers .... The only heat you have is from the

\footnotetext{
51 Sanchez interview, August 2, 2013.

52 Ibid.
} 
stove..$^{53}$

Hector Hinojosa also described conditions that were a far cry from what recruiters in Texas had promised. He recalled working full days at age twelve, "really hard labor to earn a day's wages .... Crawling on your knees in the mud or dry conditions in the sun. Back then you didn't have any of the conditions that are required today by OSEA [Oregon Safe Employment Act] or Department of Health. They didn't have running water. They didn't have utilities. I mean you went behind a bush." 54 Enedelia Hernandez Schofield, who moved to the area at age four with her family in 1962, also worked in the field as a child when not taking care of her younger brother. She recalled, "there was no such thing as staying back because you're sick. If you're sick you're still out there and picking as much as you could."55 Members of these migrant families had little choice but to work in the most trying circumstances and punishing conditions for abysmally low pay and with future work opportunities uncertain.

\section{"This is where we want to stay"}

Despite the false promises of recruiters, hard labor, poor living conditions, and the racism that the settling families encountered, Oregon seemed better, or less bad, than other places they had lived and worked. Historian Glenn Anthony May recounted how institutionalized racism and discrimination pushed many to consider relocating outside of Texas. Joseph Hernandez Gallegos, whose son Joseph Gallegos went on to become the representative for district 30 in the Oregon House

53 Ibid.

${ }^{54}$ Hinojosa interview, July 29, 2013.

${ }^{55}$ Hernandez Schofield interview, August 28, 2013. 
of Representatives in 2013, "hoped to escape the racism and ethnocentrism that existed in the Southwest," even as he chose to relocate to Portland, a city with a poor record of race relations, during World War II. ${ }^{56}$ In Washington County, in Portland, and in the state of Oregon, ethnic Mexicans were not treated on equal footing with whites (and Portland had developed a more formal segregation between blacks and whites that was akin to that which prevailed in many Southern states) but those who settled permanently in Washington County were able to leave the entrenched segregation and deep-seeded racism of Texas. While all three tejano narrators interviewed for this project experienced significant hardships and combated structures of cultural and ethnic discrimination in Oregon, their struggles were not against a long-established, heavily-entrenched system of social segregation and systematic intimidation like the one that prevailed in Texas.

Multiple factors encouraged families to abandon the cycle of migratory labor and settle in Washington County on a permanent basis, a move that allowed most to eventually transition out of grueling agricultural work. Hector Hinojosa and his siblings helped convince his parents to stay. "Of course we loved the beauty and the green. So it was more the family, us kids who didn't want to go back. Mom and dad wanted to continue to migrate back and forth and we just fell in love with Oregon and basically boycotted mom and dad and said, 'No, we don't want to go back. This is where we want to stay."'57 As a child, Erasmo Gamboa migrated seasonally with his family for farm work. He described some of the factors that made the state favorable

\footnotetext{
56 May, Sonny Montes, 35.

${ }^{57}$ Hinojosa interview, July 29, 2013.
} 
to migrants: "Oregon was particularly attractive due to its lush vegetation andbecause we were heavy consumers-to the absence of a sales tax. Moreover, when we were needed, and in comparison to residents of Texas and other states, Oregonians treated us surprisingly well."58 Pay for Oregon farm laborers averaged $\$ 1.116$ per hour in 1959 , second only to Washington state's $\$ 1.209$ average and well above the national average of 73 cents per hour. ${ }^{59}$

Erasmo Gamboa described the general pattern for the settlement of the first ethnic Mexican families in Oregon in Nosotros: The Hispanic People of Oregon. According to him, "throughout the state the pattern was similar. One or two families would decide to stay rather than migrate elsewhere, and the next year others would do the same. Generally, it began with those families that had visited the state for several years." 60 This relocation was a decision that many families made in a context of constrained choice. Oregon may have had its comparative advantages to Texas and other states, but circumstances beyond families' control compelled or outright forced some to stay. Sanchez noted the importance of keeping her children continually enrolled in one school system in her decision to remain in Oregon; academic disruptions owing to constant relocation had forced her oldest son to repeat the first grade. She also spoke of limited finances that left her family unable to pay travel costs associated with seasonal migration: “we didn't make enough

\footnotetext{
58 Erasmo Gamboa, "Introduction," in Nosotros: The Hispanic People of Oregon. Essays and Recollections, edited by Erasmo Gamboa and Carolyn M. Buan (Portland: Oregon State University Press, 1995), 13. 59 “'Forgotten' Million," Oregonian, November 4, 1959. ${ }^{60}$ Erasmo Gamboa, "Introduction," in Nosotros: The Hispanic People of Oregon, 16.
} 
money to go anywhere that year."61 Receiving extremely low wages for agricultural work, wages often lower than what recruiters had initially promised, some families found themselves stuck in Washington County after the end of a growing season. ${ }^{62}$ The additional time spent in Washington County made the families more familiar with the area, more aware of local opportunities, and therefore less likely to leave when they finally acquired the funds to be able to do so.

Some Oregon residents and organizations were concerned with the living and working conditions of migrant farm worker families, and they did provide some limited services and protections for migrants by the time that a year-round Mexican-ancestry community was starting to form in Washington County. The Oregon State Council of Churches, a cooperative agency formed in 1935 that counted most of the state's Protestant churches as members, began to offer classes and activities for migrants in the late 1950s-including summer school programs for children of migrant families created in partnership with the Oregon College of Education. The council advocated for action to improve conditions for migrant workers. Pressure from the council and from the Oregon State Bureau of Labor prompted the state legislative assembly to create a Legislative Interim Committee on Migratory Labor. This committee and the Oregon Interagency Committee on Migratory Labor, established by Governor Robert Holmes, generated reports in 1958 and 1959 on migrant living conditions. The reports prompted the passage of

61 Sanchez interview, August 2, 2013.

62 Utilizing the oral history interview she conducted with Lorenzo Rubio, Amie Thurber described how the Rubio family similarly ran out of funds to leave the county. Thurber, "The History of the Latino People of Washington County," 11. 
four bills "covering labor contracting, worker transportation, housing standards, and an education pilot program for migrant children."63 The Oregon Migrant Health Project, created from the federal funding provided through the Migrant Health Act of 1963, offered some basic health care services for migrant families. The Migrant Education Program provided educational services for children of migrant families during the regular school year. ${ }^{64}$

\section{"It was a very isolating feeling at first and then more families started to settle in and the crowd got bigger"}

In Sonny Montes and Mexican American Activism in Oregon, Glenn Anthony May noted the difficulty of estimating the ethnic Mexican population of Oregon in 1960, just two years before the Hernandez and Hinojosa families arrived in Washington County. "The census of 1960 did not attempt to provide counts of Mexican Americans, nor did it, like recent censuses, enumerate all U.S. residents of Hispanic heritage."65 May used other sources of data from the census-counting those who claimed Mexican birth or who had a Mexican-born parent in a survey on those of foreign birth—to estimate the state's ethnic Mexican population. "The number of Oregon's Mexican American residents was unquestionably small—less than 0.3 percent of the state's population in 1960, even if we use the upwardly adjusted figure of 5,000 for the Mexican American total." 66

63 Gonzales-Berry and Mendoza, Mexicanos in Oregon, 62.

64 Ibid.

65 May, Sonny Montes, 33.

${ }^{66} \mathrm{Ibid}$. Glenn Anthony May wrote that 3,119 people claimed birth in Mexico or that a parent had been born in Mexico on the 1960 survey. As the survey did not ask respondents about grandparents and great-grandparents who had been born 
Washington County, like the rest of Oregon, had very few year-round ethnic Mexican residents in the early 1960s. Enedelia Hernandez Schofield's father, Emilio Hernandez, recalled that they were only one of four families at the time of their relocation in 1962. One family lived in Hillsboro, two lived in Cornelius, and the Hernandez lived in Forest Grove. ${ }^{67}$ Hector Hinojosa recalled that there was only one other Latino student when he first attended J.W. Poynter Middle School.68 Evangelina Sanchez mentioned the scarcity of other Mexican American families residing in the area when she and her family settled in 1967: "there were so few of us and I think the only place we got together was if we had dances or community events ... It was a very isolating feeling at first and then more families started to settle in and the crowd got bigger." ${ }^{99}$ Sanchez recalled meeting new families when they would show up at church, as most shared a Catholic background, and through school functions for children of the families: "there was so little of us that we really did try and stay with each other in order to have that cultural base you long for."70 Seeking work and residence off the farms and migrant camps, the first settler families gradually formed a community shaped by both their common culture and their common struggles.

\footnotetext{
abroad, May estimated the ethnic Mexican population of the state to be between 4,000 and 5,000 in 1960 and 6,000 by 1965 .

${ }^{67}$ Emilio Hernandez, oral history interview by O'Rourke, March 22, 2000.

${ }^{68}$ Angie Chuang, "Diversity Comes to Oregon," Oregonian, March 18, 2001, A01.

${ }^{69}$ Sanchez interview, August 2, 2013.

70 Ibid.
} 
“'You're Mexican, you shouldn't be here.'”

The Mexican-ancestry community took on a vital role for the members of these families, but in their daily lives these individuals faced difficult interactions with English-speaking society-with people who for the most part had no knowledge of the Spanish language or Mexican American culture. While narrators were able to become friends with some non-Mexican residents, they also struggled to recognize and confront the prejudices that were operating against them on an individual and societal level. In order to provide for his family, Emilio Hernandez eventually secured two jobs. He worked as a truck driver for a farmer and as a machine operator at Tektronix Corporation in Beaverton. His wife, Hortencia Hernandez, continued to work as well. Their hard work enabled the family to purchase a home in Forest Grove in 1967. Instead of interviewing the Hernandez family, "a TV station interviewed the neighbors, asking them how they felt about living next to Mexicans." 71

Hector Hinojosa and Enedelia Hernandez Schofield experienced difficulties in school during the late 1960s and early 1970s. Hinojosa spoke of the pain of being forced to speak only in English while at Hillsboro High School: "When you're denied your language, your heritage ... it is a blow to who you are as an individual."72 Although he had a working command of English by the time he entered high school, it was still his second language. Lacking the opportunity for specialized linguistic instruction, he continued to find certain aspects of comprehension challenging. Not

${ }^{71}$ Amy Martinez Starke, “Life Story-Emilio Hernandez," Oregonian, February 11, 2007.

${ }^{72}$ Hinojosa interview, July 29, 2013. 
long after beginning high school Hinojosa found himself struggling to graduate due to a strict attendance policy that penalized him for family-related absences. He would often have to leave school to interpret for his parents for "everything from banking to a doctor's visit to the mechanic's shop....Things that my white friends, European Americans, didn't have to deal with those issues, I did at home."73 During his sophomore year he lost credit for all of the year's courses for exceeding the number of permissible absences, making an on-time graduation impossible. Hinojosa dropped out and began working full-time to help financially support the family. ${ }^{74}$

Enedelia Hernandez Schofield also recalled painful memories from her school years. Making financial sacrifices, her parents were able to send her to St. Anthony's Catholic School, a small school where "you got to know everybody." ${ }^{75} \mathrm{~A}$ common religion may have helped to downplay cultural differences. At the time, Hernandez Schofield did not feel that she was in any way different from her nonMexican peers, "Yet I do look back and wonder why there were some families-I never got to go visit their homes ... was it because of the color of my skin or because I spoke another language or ... you know, what was it?"76 She was too young to think anything of it when her first-grade teacher found Enedelia too unfamiliar and too difficult to pronounce and decided to call her "Annie" instead. Hernandez Schofield accepted this name until after high school. She only eventually came to feel

\footnotetext{
${ }^{73}$ Ibid.

74 Ibid.

${ }^{75}$ Hernandez Schofield interview, August 28, 2013.

76 Ibid.
} 
that "Annie," imposed on her in a culturally and individually insensitive fashion, obscured her true name and identity. ${ }^{77}$

After her elementary years, Hernandez Schofield attended the public Neil Armstrong Middle School in Forest Grove. An incident there forced her to realize that she was not being treated the same as other students: "I was in the highest math class. And the teacher at that time was like, 'What are you doing in this class? You're Mexican, you shouldn't be here.' And it was kind of that wake-up call of, oh somebody sees me as somebody different."78 That same math teacher later forced Hernandez Schofield to retake a math test multiple times, not believing that she could have done so well without cheating. ${ }^{79}$

Narrators experienced discrimination in other settings in Washington County. Sanchez remembered being followed around in stores by owners or employees, and recounted the story of her son being called a "dirty Mexican" by the woman working at the counter of a grocery store in North Plains when he went to buy candy after a day of fieldwork. ${ }^{80}$

Hinojosa explained how discrimination operated differently against him in some situations than it did for other ethnic Mexicans on the grounds of his appearance. His mother's side of the family was of primarily European ancestry, and "I got the light-colored skin and hazel eyes and so yeah, I was often told that I was different from my friends. ... I think that it helped a lot ... that I was able to walk

77 Ibid.
${ }^{78}$ Ibid.
${ }^{79}$ Ibid.
80 Sanchez interview, August 2, 2013. 
into a facility without anybody even doing a second look." 81 At age twenty-one, Hinojosa overheard a conversation in a nightclub between two young white males. One encouraged the other "to do something constructive and go kill a Mexican."82 Hinojosa revealed his ethnicity, and confronted the men. The two said that they were joking and declined to act on their words. ${ }^{83}$

Discrimination threatened the settling families, most of them also struggling to overcome severe poverty. The history of ethnic Mexicans in Washington County is not a narrative of passive victimization in the face of racism, however. The narrators and other ethnic Mexican residents and migrant workers in the county actively combatted prejudice and sought to protect their legal rights and preserve and honor their culture. As the 1960s and then the 1970s wore on, social change, new governmental policies on state and national levels, and the Chicano Movement offered increasing opportunities for the improvement of both individual and community fortunes. "Originating as a series of localized protests erupting in NM, CO, TX, and CA early in the decade, by 1968 this militancy had taken on the characteristics of a cohesive social movement," wrote David Gutiérrez of the Chicano Movement in his book Walls and Mirrors. ${ }^{84}$ Ethnic Mexicans were inspired by developments of the movement to further their own activism in Washington County and the larger Willamette Valley region, though they did so through more moderate and cautious methods than activists in the Southwest.

${ }^{81}$ Hinojosa interview, July 29, 2013.

82 Ibid.

83 Ibid.

84 David Gutiérrez, Walls and Mirrors, 183. 
Federal funding and community organizing

Although the state-sponsored reports of the late 1950s had prompted the Oregon legislature to pass several bills regulating working and living conditions for migrant workers and their families, the state lacked methods of enforcing them. It took the federal government, and the federally funded Valley Migrant League (VML), to change that. The VML and other local and regional organizations and government programs realized other tangible benefits for ethnic Mexicans in Washington County as well. In 1964 President Lyndon B. Johnson's Economic Opportunity Act established the Office of Economic Opportunity (OEO). This set aside funds for national programs such as Job Corps, which provided vocational training to poor young adults, and Volunteers in Service to America (VISTA), which sent volunteers to help economically disadvantaged communities. ${ }^{85}$

The act set aside federal funds for start-up organizations on a local or regional level. Tom Current, who had long been sympathetic to migrant workers, persuaded other migrant allies in the upper Willamette Valley to help create an organization to assist workers and their families. This work resulted in the creation of the Valley Migrant League (VML), which received an initial grant of $\$ 681,000$ from the OEO in March of 1965. The VML originally had five area offices or "opportunity centers" in the Upper Willamette Valley: in Woodburn, Independence, Stayton, Dayton, and—for Washington County-Hillsboro. ${ }^{86}$ According to Erasmo Gamboa, “the importance of the VML as a catalyst for Oregon's Chicano Movement

85 During the first Clinton Administration, VISTA became part of the newly created AmeriCorps program.

${ }^{86}$ May, Sonny Montes, 47 - 49. 
as well as an entity that addressed the agricultural workers' needs cannot be emphasized too strongly." ${ }^{77}$ The first VISTA volunteers arrived in Oregon in June of 1965, and forty-six of them were initially assigned to the VML by the OEO. 88 Emilio Hernandez, the father of narrator Enedelia Hernandez Schofield, began attending Valley Migrant League meetings in late 1965 or early 1966. While attending he was impressed by the work of Hillsboro area director Ruby Ely, who favored direct action and intervention on behalf of migrant workers. She also wanted to give current and former migrants more power in the organization's decision-making process. She brought in two seminarians studying at the Mt. Angel Seminary in Marion County to work with her at the Hillsboro center: José Jaime, originally from Mexico, and Jose Garcia, originally from California. Jaime and Garcia began to work with twelve ethnic Mexican families, including the Hernandez and Hinojosa families in Washington County, who had already banded together to create better opportunities for this small but growing community. Garcia, Jaime, and the families created Los Amigos Club in 1966 to help community members purchase homes or deal with costs associated with the death of a family member or other emergencies..$^{89}$ Jose Garcia hired Sonny Montes to work as a program aide at the VML's Hillsboro center. The Texas-born Montes had relocated to Oregon earlier that

${ }^{87}$ Erasmo Gamboa, “El Movimiento: Oregon's Mexican-American Civil Rights Movement," in Nosotros: The Hispanic People of Oregon, 48.

${ }^{88}$ J. Blaine Schulz, "Oregon to Get Corps to Aid Farm Migrants," Oregonian, March 20, 1965, 1. May, Sonny Montes, 49.

${ }^{89}$ Los Amigos Club was a direct organizational predecessor to Centro Cultural of Washington County. 
year to work at a farm in Cornelius where his wife's brother was a supervisor. Hardworking and charismatic, Montes quickly rose through the ranks of the VML. ${ }^{90}$ While Ely was realizing gains in Washington County, her approach clashed with VML board members, most of who were well-off whites. Some of these board members, twelve of the forty being farm owners in 1965, had their own interests at heart even as they advocated for better conditions for migrants. ${ }^{91}$ Reverend Kent D. Lawrence of the Westminster Presbyterian Church in Portland announced the approval of the OEO grant for the VML to the Oregonian in 1965. Lawrence explained that the services the VML would offer would entice more migrants to come to work in the region for the first time or return season after season. Area farmers could attract a "better grade of migrant" because of the VML. The program, then, appealed directly to the economic interests of farm owners. Whether or not farm owners cared about improving the lives of migrant workers, they could support a program funded by federal dollars (not their own) that would attract more and "better" workers who could make them more money. ${ }^{92}$

Ely's migrant worker advocacy resulted in her firing in 1966, and many of the staff of the Hillsboro opportunity center left the Valley Migrant League to start a new organization with her. Emilio Hernandez turned down an offer to work for the VML to become involved with the new organization. From his perspective, the VML of 1966 was not truly concerned about the well being of farm workers. "It was

\footnotetext{
90 May, Sonny Montes, 18. Gonzales-Berry and Mendoza, 79. 91 "Social Agencies Crowd Field in Try to Aid Migrants," Oregonian, September 19, 1965.

92 Schulz, “Oregon to Get Corps to Aid Farm Migrants,” March 20, 1965, 1.
} 
allright [sic] to be helped while we were here so long as we left after the season was over-that's what it seemed like they were saying. I felt that was a form of discrimination and I told the VML not to count on me for anything."'93 Ely, Hernandez, and others combined their passion of helping migrant farmworkers with their experiences learned from participation with the Valley Migrant League to create Volunteers in Vanguard Action (VIVA). Hernandez became the director of the organization. ${ }^{94}$

VIVA's creation and split from the VML both reflected and furthered the trend toward increasing migrant and farmworker control of the organizations created to assist them. The VML's leadership was pressured to yield power to ethnic Mexicans and/or current and former migrant workers. Hector Hinojosa elaborated on the efforts of two non-Mexican allies, John Hughes and John Little, who came to advocate for greater migrant control of the organization:

They recognized right away that they needed a Hispanic running those programs to address what I just finished describing as this culturally and linguistic - the gap that was missing. ... They realized that they still didn't understand all the idiosyncrasies of the cultural divide that needed to be filled in order to provide the appropriate services. ${ }^{95}$

Before returning to California, Jose Garcia assumed Ely's old role as Hillsboro's area director. John Little was then hired to fill Garcia's position. ${ }^{96}$

\footnotetext{
93 Robert Olmos, "Former Migrant Mexican Farmworker Seeks Means to Assist Other Seasonal Laborers," Oregonian, June 22, 1966, 29.

94 May, Sonny Montes, 50 - 52.

95 Hinojosa interview, July 29, 2013.

96 May, Sonny Montes, 58.
} 
Little recognized Sonny Montes's talent and hard work. He was sensitive to Montes's concerns and gave him the respect of an equal; this respect encouraged Montes to elaborate on his complaints that ethnic Mexicans and farmworkers were underrepresented at the VML as employees and decision makers. After Little became the organization's executive director and Montes became the director of the Hillsboro and then the Woodburn center (once the Hillsboro center closed), the two used their additional influence in 1968 to help transform the VML into an organization largely governed by farmworkers. Little then made preparations to turn the executive director position over to an ethnic Mexican. He hired Francisco "Frank" Martinez of New Mexico, who had formerly worked as a priest, as an education specialist in late 1968. At the end of 1970, Little gladly accepted the VML board's decision to name Martinez as his replacement. Changes did not take place without internal tension and conflict; many of those within the VML's power structure reacted negatively to losing control over the organization. May called the 1968 transfer of power "a seminal event in the emergence of a Chicano movement in Oregon."97 The VML was restructured to support migrant-driven initiatives, its power structure transformed from within by Montes, Little, and their allies.

Conflict over the VML exposed tensions between former and current ethnic Mexican farmworkers, white allies, and farm owners. As activism grew in Washington County and the Willamette Valley, conflict occurred between ethnic Mexicans as well; individuals clashed on how to best advance the movement. Lorenzo Rubio, who began working at a radio station in Hillsboro offering Spanish${ }_{97}$ May, Sonny Montes, 58 - 61, 75. 93- 98, 126 - 129. Quote on 98. 
language programming in 1972, was featured in Gonzales-Berry and Mendoza's Mexicanos in Oregon. He remembered:

It was a very active community but there was a division within the mexicano community. At that time Lionel Lucero, Sonny Montes, and a bunch of others were more conservative if you want to label them; and there was [Guadalupe] Bustos and his followers who were more liberal. They had their own ideological concepts about what we should be doing there to help mexicanos and how to do it.98

Gonzales-Berry and Mendoza described the Chicano Movement in Oregon as less radical than in Texas, Colorado, California, and New Mexico. Oregon lacked a large and long-established ethnic Mexican population that fueled strident social and political affirmations of Chicano identity in those states. ${ }^{99}$ In Washington County and elsewhere in Oregon, activists disagreed over tactics, but ethnic Mexicans realized gains largely through comparatively cautious and measured steps. VIVA did not receive the federal funding that fueled the VML, but its members and its allies, through monetary contributions and long hours of work, helped to improve the opportunities of migrant families and those attempting to transition from migrant life into permanent residence in Washington County. VIVA members used their own cars to provide rides to migrants looking to settle in order to help them find places to live and jobs outside of seasonal agricultural work and the migrant camps. ${ }^{100}$ Along with Guadalupe Bustos, mentioned above by Rubio, VIVA was instrumental in the establishment of a co-op gas station in Hillsboro

98 Gonzales-Berry and Mendoza, Mexicanos in Oregon, 99. ${ }^{99}$ Ibid., 78. 100 Olmos, "Former Migrant Mexican Farmworker Seeks Means to Assist Other Seasonal Laborers," Oregonian, June 22, 1966, 29. 
where Hector Hinojosa worked as a manager after dropping out of Hillsboro High School. VISTA volunteers worked with VIVA and provided community members with important practical skills. ${ }^{101}$ These volunteers helped Hinojosa learn the skills necessary to manage a business:

They helped us with skills on community organizing. They brought bookkeeping and accounting to the table. They brought management skills to the table. They were able to teach us these skills that we needed. Very few of us were bilingual and so we needed, those people needed to be bilingual as well. ${ }^{102}$

Hinojosa compared the VISTA volunteers to Peace Corps workers-conscientious individuals who assisted an economically disadvantaged community for a set period of time. Some of the VISTA volunteers helping the ethnic Mexican community of Washington County ended up residing in the area long-term and continued working with the community. Jim Zaleski, a former volunteer, went on to become the executive director of the Virginia Garcia Memorial Health Center in $1984 .{ }^{103}$

\section{Legal challenges to discrimination}

The late 1960s also witnessed the first legal challenges in the county that activists and migrant workers mounted against farm owners. In 1969, two years after Evangelina Sanchez and her family settled in Washington County, Sonny Montes and Lois Heinlen, a VISTA worker, entered Ronald Tankersley's North Plains farm to speak with several migrant worker

\footnotetext{
101 Gonzales-Berry and Mendoza, Mexicanos in Oregon, 80.

102 Hinojosa interview, July 29, 2013.

${ }^{103}$ Ibid. Robert Olmos, "New Health Director to Expand Care for Migrants," Oregonian, January 24, 1984, 52.
} 
families. Montes and Heinlen were acting on the plans of VML director John Little. If Tankersley had them arrested for trespassing, this would create grounds for a court ruling on the issue of access to camps and migrant workers. Little reasoned that the courts would side with them, and against the farm owner for interfering with a federal program. Tankersley confronted Montes and Heinlein, called the police, and, with his friends, began pushing them. ${ }^{104}$

Tankersley declined to arrest the two, suggesting that he suspected a plan on their part to test his right to block their access. In speaking with a reporter for the Oregonian, Tankersley claimed that he had initially mistaken Montes and Heinlein for VIVA workers, saying that VIVA employees fostered "hate against me" in their discussions with farm workers. Had the two been VIVA employees, Tankersley would not have had to worry about the legal battle that Little was hoping to win with the VML. VIVA was not a federal program, and their activism would likely not have trumped the property rights that Tankersley and other farmers had been exercising for decades to prevent farm workers from seeking outside assistance. ${ }^{105}$

Tankersley's decision not to arrest the two avoided a legal battle in Washington County over farm worker rights and access to outside help. The arrests of VML affiliates on a farm near Jefferson, Oregon, several weeks later provided the test case Little was hoping for. While the judge ruled in favor of 104 May, Sonny Montes, 122 - 123. 105 “U.S. Attorney Checks Farm Dispute Claims," Oregonian, August 12, 1969, 11. May, Sonny Montes, 119 - 122. 
the right of the affiliates to enter the farm, some Oregon growers defied the decision and resisted the entry of VML employees during the next harvest season. The VML responded by involving the U.S. Department of Justice and the Portland U.S. Attorney's Office. These federal agencies then guaranteed the rights of VML workers to enter migrant camps on private property. The guidelines for access that were subsequently established in Oregon served as a template for securing the rights of social service workers to enter migrant camps nationwide. ${ }^{106}$

While Tankersley avoided a legal battle with the VML, only several weeks later he was faced with a suit brought by migrant workers themselves. Eight migrant workers, with the assistance of bilingual attorney Noreen Kelly Saltveit, filed a class action complaint in U.S. District Court on behalf of thirtyfive workers for the farm alleging false promises and defrauded wages. Totaling differentials between promised and delivered wages, housing conditions, food supplies, medical care, and transportation costs, the workers charged that Tankersley owed compensation totaling more than $\$ 10,000$ per person. ${ }^{107}$

106 Ibid.

107 "Workers Suit Against Berry Farmer Charges Contract on Wages Broken," Oregonian, August 26, 1969, 13. Lorenzo Rubio (the same individual featured in Mexicanos in Oregon) was featured as a narrator in Amie Thurber's "Weaving Community." In this paper, Thurber stated that Rubio's mother was one of the farm workers who collectively brought suit against Ronald Tankersley. For bringing the suit, the Rubio family was kicked off of the Tankersley farm. See Amie Thurber, "The History of Latino People in Washington County: Weaving Community," 11, 39. 
The suit led to a protracted legal battle. In August 1970, roughly a year after the suit was originally filed, a judge ruled cautiously in favor of the workers, finding that Tankersley had committed a breach of contract but also that the plaintiffs were not entitled to damages, as there was no proof Tankersley that made his initial promises in bad faith. ${ }^{108}$ Plaintiffs then filed individual damage complaints. By late 1971, Tankersley had had enough and offered to settle with the workers. While the damages awarded in the stipulated judgment of December $1971-\$ 8,000$ to the workers collectively and $\$ 2,000$ to Saltveit for her legal services-were miniscule in comparison with the amount originally sought, the workers had secured an important victory in an era when courts were usually hostile to migrant workers and Latinos, and when most courts did not provide interpreters for Limited English Proficiency individuals. ${ }^{109}$

In his teens, Hinojosa became aware of how discrimination was operating at a structural level, and he became increasingly involved in challenging discrimination as he grew older. He recalled:

Seeing a home that has a sign outside that says 'For Rent', sending the family there who just came to town of Mexican descent and [them] being turned away saying, "the house has been rented already." And

108 "Washington County Berry Grower Ruled Guilty of Breaching Migrant Pact," Oregonian, August 14, 1970, 13.

109 “Migrants Win Damage Suit," Oregonian, December 14, 1971, 48. For an overview of the case, see the paper written by Mary Ann Casas for a seminar course taught by Glenn Anthony May. Mary Ann Casas, "Moreno vs. Tankersley: The Migrant Class Action of 1969," (University of Oregon Libraries, 2005). https://scholarsbank.uoregon.edu/xmlui/bitstream/handle/1794/2513/casas.pdf? sequence=1, accessed March 10, 2014. 
then watching another couple come in-European American couple come in and given an application to fill out. Obviously what we did is we then set up another couple to go in, European American and request, and were given an application. [Then we] sent a Mexican family in and they were turned away. And with the assistance of Legal Aid, Oregon Legal Aid back then was a federal program, we were able to file discrimination suits against housing. 110

\section{Higher education}

At age sixteen, Hinojosa returned to school through the Portland Job Corps to receive vocational training and obtain his GED. Impressed with his abilities and his work ethic, Job Corps offered Hinojosa a scholarship to attend Portland State University to focus on guidance and counseling. Hinojosa accepted and balanced his studies there with part-time work as a counselor for Job Corps. As his career progressed, Hinojosa was able to combine his work and educational background with his own experiences as an ESL student to help struggling students and assist organizations in becoming more sensitive to people of other cultural and linguistic backgrounds. ${ }^{111}$

Evangelina Sanchez found work and educational opportunities through state and federal programs, and eventually through Colegio Cesar Chavez. As she was bilingual and had graduated high school, Sanchez possessed the skills to leave agricultural work and provide educational services to migrant students. In the early 1970s she began work with the Migrant Education Program, under Migrant Area

\footnotetext{
${ }^{110}$ Hinojosa interview, July 29, 2013.

111 Hinojosa interview, July 29, 2013.
} 
Director Jose D. Garcia, 112 as a home school counselor. After completing a course on ESL instruction, Sanchez worked as an ESL teacher at Cornelius Elementary School. "A lot of teaching experience. I loved it though. I learned a lot."113

A scholarship from the VML allowed Sanchez to take classes to become a beautician, but funding for the league was cut off and Sanchez's scholarship was discontinued. She was forced to withdraw from classes and temporarily turn to public assistance to help support herself and her children. Sanchez recalled this as a very difficult period of her life, and she endeavored to make sure that neither she nor her children would ever have to depend on public assistance again. "The questions they ask are very dehumanizing. They're very invasive."114 This setback did not keep Sanchez from pursuing higher education. Jose D. Garcia helped Sanchez design a flexible schedule with the Migrant Education Program to allow her to attend classes at the recently established Colegio Cesar Chavez in Marion County's Mt. Angel.115 The flexible scheduling options and culturally sensitive policies of the college helped Evangelina Sanchez obtain her degree from the institution. Hector Hinojosa was directly connected with Colegio as well; he worked for a year as a recruiter for the college.

Sonny Montes had an important role in the creation of Colegio Cesar Chavez. Montes left the VML to begin work at Mt. Angel College in 1971 as a recruiter of

\footnotetext{
112 Jose D. Garcia was from Texas, a different individual than the Jose Garcia from California who worked with the Valley Migrant League.

113 Sanchez interview, August 2, 2013.

114 Sanchez interview, August 2, 2013.

115 Colegio Cesar Chavez was formerly Mt. Angel College, where José Jaime and Jose Garcia of California attended seminary.
} 
Mexican American students. Mt. Angel was already in deep financial trouble when Montes arrived. The college attempted to expand its diversity initiatives as part of a broad effort to reverse trends of declining enrollment. Montes was influential in the hiring of Ernesto Lopez, a PhD student in the University of Oregon's School of Education program, as the academic dean in 1972, and in the hiring of Jose Romero, who was about to begin the University of Oregon's political science PhD program, as the director of Chicano studies in 1973.116

By late 1973, Mt. Angel College was on the verge of shutting its doors. "Lopez, Sonny, and other Mexican Americans argued that they be given a chance to run the school."117 Lopez assumed the role of president, Romero became the dean, and Montes was named director of student services. In the following months the organization changed its name to Colegio Cesar Chavez. The administration took on the challenges of reworking the curriculum, attracting a student body comprised mainly of Mexican Americans, bringing in faculty members, regaining accreditation status (which was temporarily achieved), and addressing the pressing debt situation inherited from the Mt. Angel administration. ${ }^{118}$

"An independent four-year Chicano college was unprecedented anywhere in the nation and became the nucleus of the Chicano movement in Oregon,"119 wrote Gamboa. Twenty-two students graduated from the school in 1977, a number greater than that year's combined total of Mexican American graduates from Oregon

116 May, Sonny Montes, 146, 149, 155 - 157.

117 Ibid., 159.

118 Ibid., 160 - 163.

119 Erasmo Gamboa, “El Movimiento: Oregon’s Mexican-American Civil Rights Movement," in Nosotros: The Hispanic People of Oregon, 58. 
State University and the University of Oregon. ${ }^{120}$ In 1978 , when she was in her midthirties, Sanchez earned a Bachelor of Arts with a major in psychology from Colegio, having completed her coursework while working and raising her children as a single mother. Sanchez shared her impressions of Colegio Cesar Chavez: "It was a beautiful experience.... When you go to most colleges there's already preconceived ideas about who you are and they're not usually very positive about Mexican people.... You could get to talk the language and you get to be with instructors that were Hispanic too. So there's a connection and that connection was important."121 After finishing his studies at Portland State University, working as a counselor at Forest Grove High School, and serving as the assistant director of a University of Oregon program for struggling high school students, Hinojosa worked at Colegio Cesar Chavez as a recruiter. He recalled being impressed with the art and literature programs that the college offered and experiencing "for the first time to be in a classroom where it's okay, not is it just okay for you to be who you are but encouraged to express it in literature and in art form. And I saw some poets coming out of there that were unbelievable in art that was being published, I mean literally in art centers." ${ }^{22}$ Hinojosa valued Colegio Cesar Chavez as an institution that recognized and embraced Mexican American or Chicano culture as distinct from, but as valid as, both Mexican culture and English-speaking U.S. culture. ${ }^{123}$

\footnotetext{
120 Ibid.

121 Sanchez interview, August 2, 2013.

122 Hinojosa interview, July 29, 2013.

123 Ibid.
} 
Enedelia Hernandez Schofield graduated from Forest Grove High School in 1977, a year before Evangelina Sanchez earned her bachelor's degree and (as will be covered in more detail later in this chapter) the same year that Sanchez and parents of other students filed a complaint against the Forest Grove School District for ethnic discrimination. ${ }^{124}$ In high school, Hernandez Schofield continued to experience discrimination; some parents would not permit their sons and daughters to socialize with her. "Oregon, it was still very lily white and so it was that kind of like 'we don't really talk about that. We're color-blind. We love all. Everybody's okay. Until you're dating my son or until you're coming over or until you're coming to my house."'125

Despite her stellar academic record and strong interest in attending college, Hernandez Schofield received no counseling or advice from the school on how to pursue higher education. She reflected on how her gender might also have influenced the school's failure to prepare her for college: "I look back through the lenses that time and I wonder what kind of support there were for women in sports, women going to college- - just the gender issue in conjunction with the race and ethnicity."126

\footnotetext{
${ }^{124}$ Evangelina Sanchez recalled her children having difficulty in county schools during the 1970s and 1980s: "my own daughter in high school was harassed because she was on the dance line, she was one of the candidates for homecoming queen.... She experienced quite a bit of discrimination." While two of her children were more outspoken and confronted discrimination at school more openly, her other two tried to ignore the name calling of other students and struggled to avoid drawing attention to themselves. Sanchez interview, August 2, 2013. 125 Hernandez Schofield interview, August 29, 2013. 126 Ibid.
} 
Through personal determination and the support of her parents, Hernandez Schofield enrolled in Forest Grove's Pacific University after graduating high school. Hernandez Schofield recalled that at Pacific she found an atmosphere that was inclusive but still allowed her to embrace her ethnic identity:

That was probably the most positive experience I ever could encounter in the sense that it is a high majority of students from Hawai'i. So I could fit right in. People thought I was Hawaiian [laughs]. The other thing is that I had professors that were multicultural professors. ... I always felt like they were making sure that I would succeed. And it was also a time when I was able to really embrace my ethnicity.... that time was really a learning opportunity and a journey for myself to get to know who I was and who I wanted to be.127 While Pacific University provided Hernandez Schofield with a positive learning atmosphere, her path through college was not an easy one. She credited her parents for encouraging her to pursue her goals: "They would say, 'You can do anything you want. You can go to college.'"128 Although their encouragement meant a lot for Enedelia, neither Emilio nor Tencha had completed many formal years of education; they could not guide her through the higher education process. Enedelia had to figure out how to succeed in college, and she had to do so while maintaining the 4.0 that was necessary to keep her scholarship and while working as a bus driver and as an assistant at Echo Shaw Elementary. "Sometimes I talk to friends who went to OSU, $\mathrm{U}$ of $\mathrm{O}$, or other places and the fun things they got to do, I never experienced it. I mean I was in books, at work, that's all I could do. I couldn't do it

\footnotetext{
127 Ibid.

128 Ibid.
} 
any other way, and so to me college was work."129 Hernandez Schofield earned her Bachelor of Arts degree from Pacific University in 1981. She went on to earn a Doctorate of Jurisprudence from the Lewis and Clark School of Law in 1985 and a Master of Arts Degree through Portland State University's Portland Public School Administrative Program in $1991 .^{130}$ Hinojosa, Sanchez, and Hernandez Schofield all balanced work and school and made a number of sacrifices in order to earn their degrees.

\section{Centro Cultural of Washington County and Virginia Garcia Memorial Health}

\section{Center}

The 1970s, which saw the three tejano narrators continue with their formal education and/or begin their careers, also saw the founding of two institutions that would have lasting importance for the county's Latino population-Centro Cultural of Washington County and the Virginia Garcia Memorial Health Center. The Hernandez family, the Hinojosa family, and other members of Los Amigos Club began in the mid 1960s to plan and raise funds for Centro Cultural of Washington County, a physical building to serve as a multi-purpose educational and cultural center for the ethnic Mexican families of the county. Their aims were realized with the opening of Centro Cultural of Washington County in 1972 in Cornelius. ${ }^{131}$ Los Amigos Club dissolved as its members focused all of their energy on the new center. The

\footnotetext{
129 Ibid.

${ }^{130}$ Hernandez Schofield interview, August 28, 2013. Hernandez Schofield interview by O’Rourke, March 22, 2000.

131 Los Amigos Club was a direct predecessor to Centro Cultural of Washington County; the former organization dissolved as its members directed their efforts toward opening and running Centro.
} 
organization drew on the influence of the Centro Chicano Cultural between Woodburn and Gervais in Marion County; this center opened in late 1971 and offered a similar array of services to provide both cultural activities and vocational training to Latino residents. ${ }^{132}$ Hector Hinojosa remembered communication between Latinos in Washington County and those in Woodburn and elsewhere that facilitated an exchange of ideas:

We had one radio station, KUYK back in 1965, 1966, somewhere in that neighborhood for two hours on Sundays, 6 am to 8 ... That was the only radio station in Hillsboro. The other radio station was in Woodburn and so cultural events and announcements went back and forth. ... My family was actively involved in the Catholic Church so we integrated with a lot of the local communities who were trying to start Hispanic outreach or Spanish masses from Portland to Forest Grove, Cornelius, Sheridan, Mount Angel, Woodburn, Salem. And so we went to the different services to support their efforts and trying to promote Spanish masses in the local church. So both religiously and culturally there was a lot of interchanging with the other communities. ${ }^{133}$ According to Carlos S. Maldonado, the establishment of centers like Centro Cultural of Washington County and Woodburn's Centro Chicano Cultural were integral goals for activists in Oregon. "The Chicano community in Oregon adapted the ideas of the Chicano Movement to the realities of their region, thus, the organizational activity for political empowerment focused on the need for socialcultural centers.... The cultural centers served as focal points for the organizational

132 Gilberto Garcia, “Organizational Activity and Political Empowerment,” 75. 133 Hinojosa interview, July 29, 2013. 
development of the community."134 Centro Cultural of Washington County played a crucial role in shaping community among the county's Latinos and in aiding members of that community.

Hinojosa and his parents were heavily involved in the efforts to create Centro Cultural "from fundraising to literally going out and looking for property ... sitting on the board, the first board of directors."135 Members would hold dances or dinners to raise money for Centro. Emilio and his wife Hortencia "Tencha" Hernandez, in addition to helping out migrants through VIVA, working to make ends meet, and taking care of their own children, fundraised for the center and volunteered their time there. Enedelia Hernandez Schofield believed that, while her mother was not in visible leadership roles to the degree that Emilio was, she was nevertheless honored for her work by the community: "My father would have a write-up but my mother also had some write-ups. So I think they were respected as a couple and they were seen as a couple. It wasn't just Don Emilio, it was [Ab]uelo and [Ab]uela [grandpa and grandma], Don Emilio and Tencha."136

Centro Cultural provided vocational, educational, art, language, and activity classes for the community. Local businesses helped sponsor some of the vocational training. In the words of Hinojosa, it served as "a place to go and learn and appreciate our culture, because we had a small resource center, but we had a resource center with books, films, tapes, videotapes, as well as audiotapes of

\footnotetext{
134 Carlos S. Maldonado, "Vivemos de la Tierra: Agricultural Workers in the Pacific Northwest," in The Chicano Experience in the Northwest, 74.

135 Hinojosa interview by O'Rourke, March 15, 2001.

136 Hernandez Schofield interview, August 28, 2013.
} 
presentations." ${ }^{137}$ At the time that Centro was established, there were few other outlets for Mexican American culture or food in the area. Enedelia Hernandez Schofield:

My kids ... can go to the Mexican aisle.... They can get on the internet and listen to music and they can listen to different genres. We didn't have that and so my parents really had to work at getting that. And I think that that's why Centro Cultural was so important, because it would be a place where you could come and share what music you wanted to hear, what food you wanted to eat and stories that you had in common about going back to Texas. ${ }^{138}$

Centro hosted a number of social events and played an important role in encouraging a sense of community. "Centro Cultural kept us together. When all the other agencies kind of dissolved, the cultural center has always been there," said Sanchez. ${ }^{139}$ The organization continued to play an important role for the county's Latinos in subsequent decades.

Centro Cultural also provided the tangible resources and an organized unity among community members that assisted in the process of forming other social service and aid organizations for ethnic Mexicans of the county. In 1975 Virginia García, the six-year old daughter of a migrant family, died from septicemia, a viral blood disease, caused by an infection from stepping on a rusty nail. Her parents had not been given instructions in Spanish from the treating hospital on how and when to give her medicine to fight the infection. The incident called attention to the need

137 Hinojosa interview by O’Rourke, March 15, 2001.

138 Hernandez Schofield interview, August 28, 2013.

139 Ibid. Sanchez interview, August 2, 2013. 
for appropriate medical treatment for Spanish speakers and for those without insurance or money to pay hospital bills. Before eventually being treated at St. Vincent Hospital, Virginia García had been denied treatment at a community hospital for lack of health insurance. Members of Centro Cultural decided to set aside a space intended for training mechanics as a health clinic. Hector Hinojosa: Within that old two-story house, in the garage where we originally had plans to start vocational training [that plan] was to put to a halt, and in that garage we put in a clinic. A triage clinic, if you can imagine that with services from people from St. Vincent de Paul who volunteered to come out, medical providers, and help us with medical issues. ${ }^{140}$

Centro Cultural, with support from St. Vincent Hospital and Tuality Community Hospital, established the Virginia Garcia Memorial Health Center. The clinic began operations just weeks after Virginia García's death. ${ }^{141}$ As with Centro Cultural, the volunteer efforts of both ethnic Mexicans and white allies kept the clinic going through tough times. The center grew from a clinic inside of a converted mechanic's garage in the mid 1970s to a hospital-sized facility with multiple satellite locations, and as of 2014 was serving more than 35,000 patients annually. ${ }^{142}$

\footnotetext{
140 Hinojosa interview, August 29, 2013.

141 Robert Olmos, "Rural Health Clinic Treats Migrants: Hospital, Group Join Forces," Oregonian, July 13, 1975, 21. The spelling of "Garcia" for the health center is not accented, as it was in sources referring to "Virginia García" the individual. 142 Hinojosa interview, July 29, 2013. Gonzales-Berry and Mendoza, Mexicanos in Oregon, 81. "About Virginia Garcia Memorial Health Center," Virginia Garcia Memorial Health Center, online at http://www.virginiagarcia.org/about/index.html, accessed January 28, 2014.
} 
After graduating from Colegio Cesar Chavez in 1978, Evangelina Sanchez began working at the health center, first as a receptionist and then with the parenting project:

I liked that because you get to train parents in parenting and stuff like that; doing social work-visiting with the families. Also working with pregnant moms and giving them advice and teaching them a lot of stuff about having a baby. [And] working with the men, which was a challenge because they don't understand post partum and stuff like that. ${ }^{143}$

On reflecting on her work with the clinic and its impact on the community, Sanchez added, "it's kind of [got a] special place in my heart... I have a lot of feelings about how many families that place helped when I was there."144

\section{"It split people off into other institutions": the demise of Colegio and El}

\section{Movimiento}

Colegio Cesar Chavez had a profound impact on the educational opportunities for ethnic Mexican Oregonians, and its policies and outlook influenced other colleges and universities, but its successes as an accredited college were short-lived. The college faced an uphill financial battle from the beginning due to the debts assumed from the Mt. Angel days. Colegio was in debt to the U.S. Housing and Urban Development (HUD) for campus facilities. College administrators clashed with HUD officials, who were highly skeptical of the Colegio's plans to repay loans and showed little flexibility in negotiating a payment schedule. With the exception of the Ford Foundation, large, donor-supported organizations comparable to the

143 Sanchez interview, August 2, 2013.

144 Ibid. 
National Association for the Advancement of Colored People or the Congress on Racial Equality did not exist as resources for Mexican American educational institutions as they did for African American colleges and universities. ${ }^{145}$

Administrators also had to fight to achieve accreditation status, struggling against the strict rules and imposed delays of the procedures of the Northwest Association's Commission on Colleges and the U.S. Department of Health, Education, and Welfare, from which they first earned and then ultimately lost conditional accreditation status. A vicious cycle of debt and accreditation woes, compounded by poor and insufficient record keeping that dated from the previous Mt. Angel administration, and intensifying administrative conflict eventually doomed the college. Faculty, staff, and administrators endured long hours and lengthy periods without pay in their struggle to save the school. The final classes were offered in the spring of 1982, and several years later HUD moved to foreclose on the campus. ${ }^{146}$

Even as Hinojosa lamented the demise of the Colegio Cesar Chavez, he emphasized the impact of the organization that extended beyond its dates of operation:

The folks that were there and left went off to other institutions. They didn't stop. They didn't kill anything. If anything it gave birth to more fingers, like avenues that people went into other institutions including $\mathrm{U}$ of $\mathrm{O}$, Portland State. Two of the folks just retired from Portland State that were back in Colegio Cesar Chavez's day. They ended up [in] Portland public school. Sonny Montes ended up there. He was president and one of the co-founders, Jose Romero just retired from

145 May, Sonny Montes, 177 - 183, 190, 191.

146 May, Sonny Montes, 190, 191, 218, 240 - 246, 249. 
migrant education. So it created leadership and it split people off into other institutions and took hold in other locations. ${ }^{147}$

After Hinojosa's time working at Colegio Cesar Chavez, he transitioned to work in the private sector, a move that reflected the impact that changes in federal funding were having on social service organizations. "Ronald Reagan was elected and he was cutting funds left and right with the Reaganomics package, and so I decided to go under private industry and left public service."148 Hinojosa found work in Salem at the Dole mushroom division of Castle \& Cooke in labor relations, and negotiated with men such as State Senator L.B. Day. He was later promoted to Castle \& Cooke's corporate headquarters in San Francisco. The former migrant worker who had been forced to drop out of high school was now representing a multinational agricultural company in their dealings with agricultural workers and their unions. Hinojosa reflected on the changed trajectory of his career path: It was 40,000 employees in twenty-seven different countries. And to serve at the corporate office in labor relations to learn union negotiations, union organizing but representing management, not the workers. So I am now learning the other side of the flip of the coin, going from literally walking the picketing on behalf of the United Farm Workers for worker rights and social justice to being a representative of one of those companies. [I] literally had the opportunity to sit down with César Chávez and Dolores Huerta and negotiate union contracts on behalf of the growers and farmers. ${ }^{149}$

147 Hinojosa interview, July 29, 2013.

148 Ibid.

149 Hinojosa interview, July 29, 2013. 
Hinojosa had a successful transition to the private sector, and felt that his skills and background enabled him to work in a manner that was advantageous to both his employer and the worker unions with whom he negotiated. The shifting social and political climate that prompted his transition, however, did not bode well for the Chicano Movement in Washington County and beyond. "As the rules for funding social programs changed," Erasmo Gamboa wrote, "Mexican Americans were caught unprepared. Anglos were also critical of the various programs that had been developed during the 1960s and 70s."150

In 1976, the U.S. Department of Labor ceased funding for Oregon Rural Opportunities (ORO), a program designed to help farm workers. While the state assumed responsibility for the project, it was not able to match the previous level of funding and immediately moved to close some of the program's service centers; the center in Hillsboro was the first to shut its doors. As mentioned by Hinojosa and mirrored by his own experiences, some activists and Chicano leaders in Oregon transitioned into mainstream educational institutions and businesses as these organizations recognized the need to address some of the demands that the movement had raised. May wrote that, after leaving Colegio Cesar Chavez, Sonny Montes "had to adopt an essentially assimilationist stance" in his subsequent work with the Northwest Regional Educational Laboratory, Interface Consultants, and Portland Public Schools (PPS).151 According to Erasmo Gamboa, "by the 1980s both the Valley Migrant League and El Movimiento in Oregon had come and gone."152

150 Erasmo Gamboa, Nosotros: The Hispanic People of Oregon, 59.

151 Robert Olmos, “State Will Handle Funding of Farm Worker Program," Oregonian, 
The Chicano Movement created social change and better opportunities for many ethnic Mexicans. By the late 1970s, social service organizations and other resources were available in Washington County that had not existed a decade before. Some of these organizations expanded their services even as federal funding prospects declined. Social problems and ethnic and cultural tension continued to persist, however. The years of Colegio Cesar Chavez witnessed worsening relations between the college and the elites and other whites of the Mt. Angel community. 153

Tensions remained and in some cases intensified between Latinos and elements of the white population in Washington County. In 1977 Evangelina Sanchez protested the abuses that her younger brothers suffered in the Forest Grove School District. She and other parents filed a complaint with the state superintendent's office alleging poor treatment of migrant and Latino children by teachers and other students. The complaint and subsequent investigation led to the implementation of multicultural training for the teachers, but the families had to proceed cautiously with their complaint. "It was a long drawn out process and at times hostile on the part of the Forest Grove community. We were afraid to complain because it was at a time when there were few Hispanics in [the] area. It took a lot of organizing and [was] time consuming."154

In late 1980 Centro Cultural successfully applied for federal funding to construct a new center in Cornelius. Construction was completed only after delays

April 2, 1976, 62. May, Sonny Montes, 250 - 252.

152 Erasmo Gamboa, Nostros: The Hispanic People of Oregon, 60.

153 May, Sonny Montes, 173 - 174.

${ }^{154}$ Evangelina Sanchez, email to author, November 26, 2013. 
imposed by the city council that put the organization through a challenging and tedious process to obtain the necessary permits. In order to avoid a lengthy and uncertain conditional-use permit application process, Centro dropped a number of educational programs it was planning to offer in the new facility. ${ }^{155}$ These delays and challenges, and the criticism of Centro personnel about the council's decisions, suggested animosity on the part of most of the city council and some residents toward the Centro. One citizen group petitioned to recall City Councilor Ralph Brown for voting in support of the new Centro Cultural facility and, therefore, "against the wishes expressed by the majority of Cornelius residents." ${ }^{156}$ The process through which Latinos made gains in Washington County was, due in large part to the relatively small size of the ethnic Mexican/Latino populations relative to the white population, necessarily slow and cautious.

Even as federal funding cuts reduced or eliminated some programs and organizations, Centro Cultural and Virginia Garcia Memorial Health Center continued to grow and offer important services for Washington County Latinos. By the 1970s and early 1980s there were new opportunities in the county for Latinos for work, education, and cultural expression. All the while, the Latino population was rapidly changing in terms of both its size and composition. Migrant streams continued to bring ethnic Mexicans to Oregon for agricultural and other work opportunities, but these individuals were increasingly Mexican nationals, not

155 "Council Holds Firm on Center Parking," Oregonian, October 6, 1981, 27. 156 "Suburban Roundup," Oregonian, September 8, 1981, 21. Diane Lund, "Conditional-Use Permit Voted for New Building," Oregonian, September 15, 1981, 58. The recall effort was put to a public vote on November 4, 1981 but was defeated 336 - 261, allowing Brown to keep his position. 
individuals from Texas or other states of the U.S. Southwest. Mexican nationals and Mexican Americans had different cultural practices and, due to the duration of their residence in the country, generally had different social and economic opportunities in Washington County. Organizations such as Centro Cultural, and their members, continued to play a role in shaping the relationships between Washington County's Mexican Americans and Mexican nationals and other Latin American immigrants as new issues and tensions emerged in a rapidly growing and changing Latino population. 


\section{Chapter II Growing Mexican and Latino Populations of the 1970s and 1980s}

\section{Narrators introduced in this chapter:}

- $\quad$ Sister Ina Marie Nosack was born in 1926 in Gervais, Oregon, and entered the convent of Sisters at Saint Mary after completing high school. Sister Ina Marie learned Spanish while working in Peru during the 1960s and 1970s. Years after returning to Oregon, she found that she wanted to continue using her Spanish and working with Latino families. She took a position at the St. Alexander Parish in Cornelius from 1984 to 1996; while working there she brought food and clothing to families living at migrant camps, helped families with childcare and other needs, and provided religious instruction to children at the parish. Sister Ina Marie was living in Beaverton at the time of the interview.

- Laura Gamboa was born in Cuautla in the Mexican state of Morelos south of Mexico City and lived there until she was twenty-one years old. In 1990, Laura moved to Washington County with her two daughters to join her husband and her mother who had relocated there a short time earlier after spending about six months working in Madera, California. She was living in Aloha at the time of the interview, which was conducted in Spanish.

- $\quad$ Arturo Villaseñor was born in Mexico in 1965. After graduating from Mexico City's Instituto Politécnico Nacional (National Polytechnic Institute), Arturo worked as a civil engineer. In 2000, Arturo moved to Washington County with his wife and children. He was living in Forest Grove at the time of the interview.

This chapter examines the factors that brought Mexican nationals and Central Americans to Washington County for seasonal work and permanent residence in the 1970s and 1980s. It explores the roots of tension between Latinos in the county, as well as opportunities and strategies for cooperation among them. Community leaders in Washington County responded differently to the large-scale influx of Mexican nationals than had community leaders in Texas and the Southwest when first faced with the issue decades prior. This chapter also highlights some of the struggles facing migrant families with regards to housing and to treatment from 
their employers, and how changes in national policies regarding undocumented immigrants influenced both the rates of immigration and the treatment of Latinos countywide.

\section{Migrants from Mexico}

"The Mexican national is gone and won't be coming back,"157 reported the Oregonian in a January 1948 article covering the termination of the bracero program in Oregon. While there was some continuous presence of Mexican nationals in the state since the end of the program, by the 1970s this claim would come to sound more blatantly false as changes in the Mexican economy and a continuing demand for farm workers helped create new migrant streams. Increasingly, families came to Washington County directly from Mexico, rather than other areas of the United States, to work seasonally and settle permanently.

The population of Mexico expanded rapidly in the latter decades of the twentieth century-from nearly 35 million in 1960 to over 48 million in 1970 to almost 67 million in 1980-while the country's economic growth occurred at a much slower rate. ${ }^{158}$ Low wages and high unemployment encouraged many to look to Oregon and other areas of the United States for work. A 1978 Oregon State

\footnotetext{
157 Harry A. Whitten, "Farm Labor: It's Back to Normal After War Emergency," Oregonian, January 11, 1948, 62.

158 National Institute of Statistics and Geography (INEGI), accessed through Google Public Data Explorer, updated 27 September 2013, online at http://www.google.com/publicdata/explore?ds=z83fj27m8fa7gq_\&hl=en\&dl=en\#! ctype $=1 \&$ strail=false \&bcs $=d \& n s e l m=h \&$ met_y=population\&scale_y=lin\&ind_y=false \&rdim=country\&idim=country:Estados+Unidos+Mexicanos\&idim=state:BC\&ifdim= country\&tstart=$1889020800000 \&$ tend $=1266739200000 \& \mathrm{hl}=$ en_US\&dl=en\&ind=false, accessed February 21, 2014.
} 
University study showed that Mexican migrant workers in the Hood River area were earning six times as much as they would in Mexico, though living costs were higher than in Mexico and migrants had to pay transportation costs as well.159

Migrants initially came from a limited number of Mexican communities. Employers needing additional help had workers recruit friends and family members from their home communities. In 1970, Hood River orchardist Eugene Euwer first hired three men from Mezquital in the Mexican state of Durango and went on to seasonally hire dozens more Mezquital workers over the following decades.

Eventually, due to direct connections, contact with recruiters, or word-of-mouth reports about work opportunities, people from communities all over Mexico began to migrate to farm areas across much of the continental United States for work. ${ }^{160}$ In 1978, the Oregonian reported that growers in the Pacific Northwest "say that as much as 75 to 90 percent of the apple and pear harvest in some areas is done by probably illegal aliens."161

Jesus Lopez of the Migrant Emergency Committee estimated that there were "between 1,500 and 1,800 migrant families in Washington County alone" in 1978.162 The ethnic Mexican/Latino population grew rapidly in Washington County. The

159 Gonzales-Berry and Mendoza, Mexicanos in Oregon, 74.

160 Gonzales-Berry and Mendoza, Mexicanos in Oregon, 73, 102, 116.

161 Alan Ota, “To Pick Pears Growers Seek Foreign Workers,” Oregonian, July 16, 1978, 44.

162 Patrice Haffey, “Migrant Fund to Help Workers Return Home," Oregonian, June 27, 1978, 27. 
Hispanic population of the county was recorded as 2,540 in 1970.163 That number rose to 6,190 in 1980 and to 14,680 by $1990 .{ }^{164}$

In Mexicanos in Oregon, Gonzales-Berry and Mendoza described the community networks that brought people to Oregon for seasonal work. According to the authors, by the early 1970s Mexican-born people settling in the Mid-Columbia River region outnumbered settling Mexican Americans. Most of the early Mexicanborn settlers were either single males or males whose families still lived in Mexico. Increasingly, families followed these males to the county as the 1970s wore on. ${ }^{165}$ Narrator Enedelia Hernandez Schofield described local changes in patterns of settlement in Washington County that mirrored the trends taking place across the larger region. "I shared that initially there were Hispanic families, Mexican American families coming from Texas.... Later that transition went into more single men from Mexico."166 Evangelina Sanchez spoke about the same changes. "Maybe in '70 the single Mexican people, guys started to come in and migrate into this area. So they kind of took over. And now there are Mexican families from Mexico living there."167

1632013 State Profile Oregon: State and County Projections to 2040, Woods \& Poole Economics (Washington D.C: Woods \& Poole Economics, 2013), 358. 164 Ibid.

$165 \mathrm{Ibid}$. Some Mexican women did not follow their husbands in coming to Oregon. Sister Ina Marie Nosack recounted the story of one woman who left an abusive husband in Mexico and braved a dangerous border crossing with her six children to create better life opportunities for them. The woman and her children found their way to Washington County. Oral history interview with Sister Ina Marie Nosack, May 9, 2013, Beaverton, Oreg. in author's possession and in the possession of the Washington County Museum. ${ }^{166}$ Hernandez Schofield interview, August 28, 2013.

167 Sanchez interview, August 2, 2013. 
The Mexican-born narrators I interviewed relocated to Washington County during the 1990s and 2000s, but they moved for reasons similar to those that prompted Mexicans to immigrate to Washington County during the 1970s and 1980s. Laura Gamboa and her family operated a refreshment stand in Cuautla, a small city in the Mexican state of Morelos south of Mexico City. Gamboa reflected on the changes that she witnessed in Mexico in the years before moving to the United States in 1990: more competition from other vendors, likely intensified by a lack of other job opportunities, and fewer sales:

Por la misma competencia pues tenías menos oportunidades de determinar tus productos que ofrecías al público.

Because of that competition you had fewer opportunities to determine your products that you offered to the public. ${ }^{168}$ Some of the early Mexican nationals found their way to Washington County and other areas of the Northwest only after first relocating to the states bordering Mexico. In the introduction to Memory, Community, and Activism: Mexican Migration and Labor in the Pacific Northwest, Chicano historian Jerry Garcia recounted his family's migratory paths. His Mexican-born parents had relocated to Texas and Arizona with their families before moving to Washington state. His mother moved to the state in 1945 , and his father in the early 1950 s. ${ }^{169}$ Garcia conducted interviews with many of his relatives:

\footnotetext{
168 Oral history interview with Laura Gamboa, October 17, 2013, Hillsboro, Oreg., in author's possession and in the possession of the Washington County Museum. All Spanish-language translations in this work are my own. 169 Jerry Garcia, "Introduction," in Memory, Community, and Activism, 6 - 8.
} 
A common theme emanating from these interviews was the wish to flee the Southwest for a better life in the Northwest. The reality of fleeing for my grandparents and their sons and daughters (my father) was a better wage and a sense of relief from the intense racism and discrimination of the Southwest, Texas in particular. ${ }^{170}$

For Garcia's family members, the Northwest held promise as an escape from the discriminatory social structure of the Southwest, even though Garcia noted that upon arrival his family members realized that these problems were not absent in the Northwest, either. In a similar fashion, Lorenzo Rubio, who was born in Mexico near Ciudad Juárez, began a migratory journey with his family that eventually brought them to Washington County in 1969. Rubio's family moved near El Paso, Texas, when he was two or three years old, and then several years later relocated to Artesia, New Mexico. After eleven years in New Mexico, the family moved to Washington County's North Plains. ${ }^{171}$ Although Hector Hinojosa was raised in Texas, continued to visit family there after decades in Oregon, and self-identified as culturally Mexican American, he was born in Mexico and his own journey is comparable to Rubio's. The Hinojosa family had moved to Texas from Mexico when Hector was very young, and years later relocated to Washington County by way of California. ${ }^{172}$ Conditions in Mexico prompted some Mexicans to first move to the

\section{Ibid., 7.}

171 Rubio, "Testimonio," in Mexicanos in Oregon, 96 - 97.

172 Hinojosa interview, July 29, 2013. As someone who left Mexico before he was old enough to remember much about it and was raised in Texas and then Oregon, Hector Hinojosa's life highlights how terms such as tejano, Mexican national, and Mexican American can serve as only imperfect markers or dividers. Nationality and citizenship status have an important bearing on one's life opportunities in the United States, but they do not always correspond with where an individual spent his 
Southwest. Many of these Mexican nationals, then reacting to discrimination and hardships in these states as had departing long-settled tejanos, left the region. By the late 1960s and early 1970s, more and more Mexican national families were arriving in Washington County.

The Hinojosa and Rubio families were from parts of Mexico bordering Texas. In the years after the early 1970s, more immigrants from other parts of Mexico arrived in Washington County. Sister Ina Marie Nosack, a bilingual nun who worked with migrant families at St. Alexander Parish in Cornelius and at various farm camps in the county in the 1980s and 1990s, recalled that many migrants came from the Mexican states of Jalisco, Guadalajara, Michoacán, and Oaxaca. Migrants came from different economic backgrounds and had completed different levels of formal education. Nosack remembered that migrants from Jalisco and Guadalajara were generally better off, especially in comparison to migrants from Oaxaca: "The ones who came from Oaxaca were so poor, didn't even have schooling. Many times hadn't gone to school at all."173

\section{Central American migrants}

While this work focuses primarily on the experiences of ethnic Mexicans, it is important to note that the 1980s saw the arrival of a significant-though, due to their undocumented status, somewhat uncertain-number of families from

or her formative years and what culture he or she identifies with. Hinojosa became a U.S. citizen in the early 1970s. See Hector Hinojosa, oral history interview by Michael O’Rourke (Hillsboro, Oreg., March 15, 2001), transcription in possession of the Washington County Museum.

173 Nosack interview, May 9, 2013. 
Guatemala and elsewhere in Central America. Nosack recalled the presence of Guatemalan migrant families in the 1980s:

They kept them in separate camps. Pretty much all the Guatemalans were in Camp Barbie, and that was a pretty big camp. Now whether they always do that I'm not sure, but I know that we had two different camps where the people were pretty much from Guatemala, and they tend to stay together. ${ }^{174}$

Several articles from the Oregonian highlighted the presence of Guatemalans and other Central Americans in Washington County in the 1980s. A 1985 article detailed a U.S. Immigration and Naturalization Service (INS) raid on a strawberry farm in Cornelius. Most of the forty-eight workers caught in the raid were Mexican nationals; four were Guatemalan. ${ }^{175}$ A 1984 article highlighting the lack of housing for migrant worker families profiled Richard M. Ginsburg, who was the head of the Housing Development Corp. of Washington County. The article stated that area churches provided space to refugees from Guatemala and El Salvador. ${ }^{176}$ Civil war in Guatemala lasted from 1960 to 1996, with the late 1970s and early 1980s witnessing especially violent reprisals from the Guatemalan military against the indigenous communities suspected of assisting guerrilla forces. According to labor historian Leon Fink, in his book The Maya of Morganton, "some six hundred indigenous communities were all but wiped off the map."177 The conflict displaced

\footnotetext{
174 Nosack interview, May 9, 2013.

175 Deedee Harrington, “Raiders Nab Illegal Aliens,” Oregonian, June 20, 1985, 40.

176 Robert Olmos, “Award-Winner Says Migrant Housing Need Great,"Oregonian, July 31, 1984, 58.

177 Leon Fink, The Maya of Morganton: Work and Community in the Nuevo New South (Chapel Hill: University of North Carolina Press, 2003), 37.
} 
roughly one million Guatemalans from Maya communities. They sought refuge in Mexico, the United States, and other countries.

The Salvadoran Civil War lasted from 1979 to 1992. As in Guatemala, the conflict was exceptionally violent and included numerous human rights violations. In Washington County, the Spanish-speaking community was becoming more diverse than the original community of tejanos and even more diverse than a solely ethnic Mexican community as Central Americans arrived in Washington County fleeing the violence and economic collapse that armed conflict had brought to their homelands.

The arrival of Mexican and Central American migrants created new issues for the Spanish-speaking population. Reporter Robert Olmos wrote that Mexican Americans suffered heightened harassment and discrimination from law enforcement due to intensifying pressures to deport undocumented immigrants-a trend likely influenced by the increasing numbers of undocumented migrants and residents in the county. Olmos reported in 1976 that Mexican American residents "say the alleged treatment is racist-inspired, committed against the Mexican aliens because they are "brown."'178 In 1982 the Oregonian reported on an upswing in raids by the U.S. Immigration and Border Patrol against the undocumented as a particular source of tension between Latinos and law enforcement. ${ }^{179}$

178 Robert Olmos, "Chicanos Fight Hard for Acceptance while Maintaining Cultural Traditions," Oregonian, July 13, 1976, 55.

179 “Police-Hispanic Gap Needs Bridging," Oregonian, September 7, 1982, 49. 


\section{"Mexican against Mexican": Intra-ethnic tension}

In 1976, Olmos wrote, "Chicanos feel a link with the aliens because of the connecting bloodlines." ${ }^{180}$ This supposed link did not, however, ensure friendship between Mexican Americans and the more recently arrived Mexican nationals. Changing demographics highlighted the differences between the Mexican and Mexican American cultures and between the opportunities for members of each group. Nosack recalled that area farm owners often hired tejanos, who spoke both English and Spanish, to supervisory positions over migrant workers. According to Nosack, Mexican American supervisors did not get along well with the Mexican migrants at many migrant camps: "So right away they disliked the Mexicans. They just-the two do not mix. And so these, whoever was in charge of the whole camp was the one that would take advantage of them terribly. To mail a letter they would charge them five dollars sometimes... If they got groceries for them, everything, everything was overcharged and put on their bill at the end of the month."181

Evangelina Sanchez, who taught English as a Second Language (ESL) to migrant Mexican children in the 1970s, offered her own perceptions of intra-ethnic tension:

There does exist, Luke, and I'll be real honest, some discrimination between people from Mexico and the people from the United States. It's the feeling that many of the people from Mexico think we're privileged because we were born here and we have all the rights of United States citizens and they don't. So there's some tension that

\footnotetext{
${ }^{180}$ Robert Olmos, “Chicanos Fight Hard for Acceptance,” July 13, 1976.
}

181 Nosack interview, May 9, 2013. 
exists because of that. There have been some casualties because of that here in this community. 182

Sanchez remembered a trip to Mexico:

I was at the airport and I was teaching this lady how to speak a few words in English to survive and she says, "You're so nice." And I said, "Well, why wouldn't I help you?" She says, "You know we have this myth about people from the U.S. that are Mexican, that they're not very friendly and so I'm just surprised that you're so nice."183 In Gonzales-Berry and Mendoza's Mexicanos in Oregon, Lorenzo Rubio, who began working with a radio station in Hillsboro that served the Spanish-speaking population in the early 1970 s, recalled "the new immigrants were coming to Oregon, mostly Mexicans and Central Americans, and they saw the Texans. Those guys didn't like the tejanos because they didn't speak Spanish well. The tejanos didn't like those people because they were always trying to correct them."184 At the station, Rubio played only tejano music at first, but began taking requests from Mexican nationals. "I think that that really helped me to play the role of bridge between the tejano and mexicano communities through music, because music crosses any kind of generation and political beliefs that one may have. Music united us in this area."185

Sanchez also mentioned the importance of music, both as an example of cultural differences and as a tool to bring the two groups together, even as she expressed her belief that Mexican migrants had been reluctant to create community with tejanos:

\footnotetext{
182 Sanchez interview, August 2, 2013.

183 Ibid.

${ }^{184}$ Lorenzo Rubio, "Testimonio," in Mexicanos in Oregon, 96 - 101.

185 Ibid., 100.
} 
It's like my brother said - he owned a band and he used to make dances and he would say, "I used to play just Texan music" which is Tex-Mex, some English mixed in and stuff like that. "And pretty soon I noticed that people weren't coming to the dances. And I knew that I had to change my music in order to accommodate the whole community." So I think for all of us that are here now that the Texans that are outnumbered, we've learned to adapt and embrace the community. I think so much more so than sometimes they embrace us because-I don't know if I should call animosity. I don't know what it would be because they are angry because we do have privileges. ${ }^{186}$ Laura Gamboa, who spent the first twenty-one years of her life in Mexico, identified strongly with Mexican culture, and felt more comfortable conversing in Spanish than in English during our interview, but she had also resided in Washington County for more than two decades and expressed concern regarding new arrivals unfamiliar with safety codes and regulations:

Pues, anteriormente cuando yo recién llegue a Aloha se me hacía una ciudad más tranquila, pero ahora que han llegado más latinos o hispanos, a veces ellos no les gusta respetar como las reglas de seguridad. Ahorita en mi vecindario ... se estacionan de las dos lados, y algo que me preocupa es si hay alguna emergencia ¿cómo va a entrar la ambulancia o los bomberos? Porque ellos están cerrando el paso para esas personas.-Well, before, when I was just recently arrived in Aloha it seemed like a more tranquil city, but now that more Latinos or hispanos have arrived, sometimes they don't like to respect the rules for security. Now in my neighborhood ... they park on both sides [of the street], and something that worries me is if there is some

186 Sanchez interview, August 2, 2013. 
emergency, how will the ambulance or firefighters get through?

Because they are closing the way for these people [to pass through].187 Unaware of norms and regulations in their new homes, the more recently arrived immigrants may have acted in ways that inconvenienced or distressed longestablished residents of both Mexican and U.S. origin and therefore contributed to intra-ethnic tension. This pattern was likely true in the 1970s and 1980s as it was in the early 2010s when observed by Laura Gamboa.

Speaking from a different perspective than Evangelina Sanchez or Laura Gamboa, Arturo Villaseñor noted the frustration that long-settled ethnic Mexicans expressed about the assistance new arrivals were receiving. Villaseñor, who moved to Washington County in 2000, noticed divisions within the Latino population, but felt they reflected different amounts of time spent residing in the county rather than country of origin and citizenship or residency status. While he made his observations on social relations decades after the 1970s and 1980s when large numbers of Mexican migrants began arriving, his observations are useful in conceptualizing the nature of tension among Washington County Latinos. When asked if he had experienced racism in Oregon, Villaseñor replied:

That's funny, most of the time it's Mexican against Mexican-people established here before against, or resenting something against the newcomers. I'm not telling that it's not rare to have an American making some statement or be racist against Mexicans. I don't see that every day, but most of the time I saw more prejudice from the

187 Laura Gamboa interview, October 17, 2013. 
Mexicans, Latinos against Latinos. I don't know, I don't like that but yet somehow it's true. 188

Villaseñor spoke of the resentment that settled residents felt about newcomers receiving assistance in the United States:

You can tell when someone established presents something like, "Oh my, these guys from Mexico are receiving these food stamps and my young son born here in the states doesn't have that kind of help." ... Sometimes they resent this, this help that sometimes people receive from the government. ${ }^{189}$

In Villaseñor's estimation, division existed between those who had been settled for some time and recent arrivals, but not necessarily because of nationality as characterized by Sanchez and Nosack. This may be indicative of changing demographics in the county between the 1960s and 2000s. Families with roots in Texas, the Southwest, or other parts of the United States went from comprising nearly the entirety of the Latino population in Washington County in the late 1960s to a minority that continues to become proportionately smaller and smaller. When Villaseñor moved to Washington County in 2000, tejanos and other Mexican Americans were a relatively small minority of the population in comparison to Mexican nationals and people from elsewhere in Latin America. Villaseñor perceived discord between newcomers and those who had been living in the county for years-a group that included tejanos, other Mexican Americans, Mexican nationals, and other Latinos.

188 Oral history interview with Arturo Villaseñor, November 11, 2013, Hillsboro, Oreg., in author's possession and in the possession of the Washington County Museum.

189 Villaseñor interview, November 11, 2013. 
"To them it was important that we did stick together"

While intra-ethnic tension between Latinos was very real in Washington County, community builders worked to welcome newcomers. Villaseñor cited the work of the founding tejanos at Centro Cultural in aiding newcomers as reason to doubt that nationality was at the root of intra-ethnic conflict:

The families that founded Centro Cultural are from Texas. Some of them, and I met them before, and they were working here. They were the first Latinos here in the area maybe 30 or more years ago.... They founded Centro Cultural because they needed a place for newcomers. And so I don't think so [regarding an essential cultural division between Mexicans and Mexican Americans]. It wasn't really a big problem with them, just some people, some bad apples. 190

Sister Ina Marie Nosack remembered Emilio and Hortencia "Tencha" Hernandez for the important work they did to help migrant families and to create a broader Latino community. "They probably were some of the really good gobetweens for both groups.... at Centro Cultural they did a lot to help the people who first got here to know what to do and what not to do.... They were two people who, who really tried." "Tencha and Emilio were my best friends. They were-she was the cook over there.... He went and got the bread and the chicken and whatever. They were wonderful people."191

Enedelia Hernandez Schofield recalled the work that her parents did for migrant families—both at Centro and in other capacities. "I remember many, many times or many hours going to the migrant camps and making blankets to then take

190 Villaseñor interview, November 11, 2013.

191 Nosack interview, May 9, 2013. 
to the migrant camps and give them to migrants." ${ }^{192}$ The Hernandez opened their home to a number of migrant men from Mexico who temporarily needed a place to stay. "We would refer to them as los muchachos [the young men] because you know, that could change on a weekly basis, daily basis, but the muchachos were always around." ${ }^{193}$ The Hernandez also hosted Father Arnold Beezer, the first priest sent to minister to the farm workers and other ethnic Mexicans in the late 1960s, and four of his assistants for four months until other housing arrangements could be made..$^{194}$ Hernandez Schofield's parents believed strongly in the importance of creating community:

I think also they wanted the best for us [their children] so them building that community allowed us to enter that in the future.... Every once in a while they would say, "remember that you may be judged by the color of your skin." So if I have somebody from Texas and you have somebody that's from Mexico and you have somebody that's from Nicaragua, at the end of the day if we're all brown looking, we're going to be perceived as however that person wants us to be perceived. So to them it was important that we did stick together in the sense of building a community because we really were a mix of that community in the brown skin that we are.195 In Walls and Mirrors, historian David Gutiérrez offered a comparable description of how treatment by non-Latinos encouraged solidarity among ethnic Mexicans in Texas. As early as the 1920s and the 1930s, ethnic Mexicans in Texas found cause to work together in labor struggles as employers treated citizens and

\footnotetext{
192 Hernandez Schofield Interview, August 28, 2013.

193 Hernandez Schofield Interview, August 28, 2013.

${ }^{194}$ Emilio Hernandez interview with O'Rourke, March 22, 2000.

195 Hernandez Schofield interview, August 28, 2013.
} 
Mexican nationals equally poorly. ${ }^{196}$ Emilio and Hortencia Hernandez felt connected to Mexican migrants through shared hardships, and they worked to create community across lines of nationality.

As community leaders, the Hinojosa, Hernandez, and other early settling families worked to welcome new Mexican migrants. Ethnic Mexican leaders in places like Texas and other states bordering Mexico had more mixed, and generally more negative, initial reactions to, and receptions of, large waves of Mexican migrants. Why did the early responses of community builders and leaders in Washington County to Mexican migrants differ from the responses of leaders in the states bordering Mexico? Individuals and families who emerged as community leaders in Washington County came from different socioeconomic backgrounds than did leaders in long established Mexican American communities in the Southwest. Additionally, community leaders in Washington County first responded to the issue of the migration of large numbers of Mexican nationals in a later time period than had leaders in the Southwest, during years when ideas of ethnic solidarity and creating a broad ethnic community had gained considerable currency.

Tejanos who emerged as community leaders in Washington County ${ }^{197}$ had come from impoverished backgrounds and, like most subsequent migrants, were

196 Gutiérrez, Walls and Mirrors, 99.

197 Lorenzo Rubio, who came to the county in 1969, and who provided aid and services to ethnic Mexicans and other Latinos through his radio program and work with the sheriff's office, was born in Mexico and spent most of his adolescence in New Mexico. He only lived in Texas for several years as a young child. Not everyone who occupied an early leadership role in the community would use tejano as a primary label of self-identification. See Lorenzo Rubio, "Testimonio," in GonzalesBerry and Mendoza, Mexicanos in Oregon, 96 - 101. 
employed as agricultural laborers upon their arrival. These community builders were personally familiar with many of the hardships that incoming Mexican nationals faced. Many of them empathized with the newcomers and worked to help them.

While poorly paid and poorly treated Mexican American and Mexican national laborers had seen the need to work together in Texas in the early twentieth century, Mexican American elites were influential in encouraging division between the two groups. In Texas, organizations like the League of United Latin American Citizens (LULAC), El Orden Hijos de América-The Order of the Sons of America, and El Orden Caballeros de América-The Order of the Knights of America emerged in the 1920s as ethnic Mexicans who were economically better-off struggled to more fully secure their rights as U.S. citizens. The leaders of these groups were often wealthy Mexican American professionals and business owners, and their membership was comprised largely of individuals who were better off than most Mexican Americans and Mexican immigrants. Although the vast majority of ethnic Mexicans in the Texas were not affiliated with these organizations, the groups were highly influential in the state. For decades their positions helped exacerbate intraethnic divisions. ${ }^{198}$

\footnotetext{
198 Gutiérrez, Walls and Mirrors, 75. The social and political positions that LULAC and similar groups endorsed upon their formation highlighted the continuity of divisions between elites and other ethnic Mexicans that had existed since the late 1800s. In many communities in the Southwestern states, small groups of elites had long wielded a disproportionate influence over the lives of ethnic Mexicans. These elite often made decisions to benefit themselves instead of the well being of other ethnic Mexicans. In Occupied America: A History of Chicanos, Rodolfo Acuña described how elites in the Southwestern United States partnered with conservative
} 
These organizations barred non-citizens from membership and moved to secure their own rights by stressing assimilation into English-speaking society. "LULAC leaders consciously chose to emphasize the American side of their social identity [rather than the Mexican] as the primary basis for organization,"199 wrote David Gutiérrez. LULAC sought to counter racism directed toward Mexican Americans, but as ethnic Mexicans suffered increased discrimination from white Americans during the Great Depression LULAC leaders "felt forced to conclude that a hard line had to be drawn between themselves and those they arbitrarily defined as aliens." 200 They believed that an open border with Mexico was detrimental to the economic interests of Mexican Americans, and that undocumented Mexican immigrants negatively influenced perceptions of Mexican Americans. ${ }^{201}$

Many Washington County tejanos experienced upward mobility in the decades after leaving Texas. Members of these tejano families occupied leadership roles in the expanding ethnic Mexican community of Washington County in the 1970s and 1980s, making their influence comparable to that of the ethnic Mexican "elites" in Texas. The small but powerful middle and upper classes of ethnic Mexicans in Texas-who had, for the most part, been long-established in their Texas communities-used geographic distance from Mexico (these families were not

white elites to help control the majority of poor ethnic Mexicans and keep them at the bottom of a highly stratified economic and racial hierarchy. See Rodolfo Acuña, Occupied America, 67, 76 - 77.

199 Gutiérrez, Walls and Mirrors, 75 - 76.

200 Ibid., 81.

201 Ibid., 85. 
moving back and forth across the border) and economic distance from undocumented immigrants to separate themselves from Mexican nationals.

In contrast, many of the tejano families who migrated to Washington County for fieldwork and who later did much of the work to create Centro Cultural and other aid organizations did not have this same level of separation from Mexican immigrants. As mentioned in chapter I, the families of the narrators had close geographic and cultural ties to Mexico. As evident from the narratives of Sister Ina Marie Nosack and Evangelina Sanchez, conflict did occur between residents and newcomers to the county, and some tejanos took advantage of Mexican migrants, but tejanos in positions of community leadership did not promote intra-ethnic tensions and divisions. A relative lack of class and cultural separation from international migrants may have encouraged these families to welcome and assist new Latino migrants at Centro Cultural.

Mexican nationals began arriving in large numbers in Washington County in the 1970s, a different era than in Texas, where there was heavy immigration during and after the Mexican Revolution and again in the 1940s and 1950s. By the time that Mexican nationals began arriving in Washington County in significant numbers, ethnic Mexicans were actively resisting the demands made by white society for linguistic and cultural assimilation. They negotiated a path for themselves that held stressing cultural pride and securing fundamental rights in the United States as complementary, rather than conflicting, goals. 
Even organizations active in the Southwest like LULAC gradually moved toward supporting the rights of undocumented immigrants after the mid-1950s. ${ }^{202}$ The Chicano Movement further encouraged a community defined by ethnicity instead of nationality. Ideas of ethnic solidarity, absent in previous decades when established Mexican American communities of the Southwest responded to heavy immigration from Mexican nationals, emerged and became highly influential and widely adopted. The language of ethnic solidarity, as promoted by the Chicano Movement, influenced the ways Mexican American residents of Washington County responded to arrivals from Mexico and Latin America in the 1970s.

Washington County's Mexican American residents did not view Mexican nationals as a direct threat to their own progress in the way that many Mexican American groups had elsewhere in decades past. ${ }^{203}$ By the 1970 s, even comparatively moderate and conservative Mexican American activists recognized that immigration policies and the treatment of Mexican and other Latin American immigrants affected the treatment of Mexican Americans in U.S. society. ${ }^{204}$ In Washington County in the early 1980s, intensifying pressure to deport immigrants contributed to increased police harassment of Mexican Americans. In Washington County and elsewhere by the 1970s, Mexican Americans came to feel that advocating for the rights of undocumented migrants would help them protect their own rights.

202 Ibid., 166 - 167.

203 Ibid., 180.

204 Ibid., 203. 


\section{"This might not be the best place for migrants to work"}

Labor shortages kept the demand for migrant workers high in Oregon and the Pacific Northwest. Sources suggest that shortages in Washington County were worsened by exceptionally poor treatment of farmworkers in comparison to other parts of Oregon. Migrant workers struggled against employer abuse.

In 1981, Oregon Legal Service’s Richard Ginsburg (the same Ginsburg of the Housing Development Corp. that constructed apartment complexes for migrant workers) cited low, stagnant wages that did not keep pace with inflation as a reason that many workers did not return. "This might not be the best place for migrants to work; they don't make much money."205 According to Ginsburg, some migrants found work elsewhere for subsequent growing seasons instead of returning annually to the county. ${ }^{206}$

Some farm owners exploited undocumented workers. In 1982, Ismael Ypolito, a migrant farmworker from Los Angeles, California, accused North Plains strawberry grower Kenneth Fields of beating him over the head with a rifle, a second-degree assault charge. According to Ypolito, he and several other workers had been fired because they had legal residency in the United States. The day after learning of the firing, Ypolito went to find Fields regarding pay owed him. Fields and his son, armed with a rifle and a baseball bat, approached Ypolito. Fields struck

205 Diane Lund, “Migrant Scarcity Hurting Farmers,” Oregonian, June 9, 1981, 47. 206 Ibid. 
Ypolito over the head. Fields claimed he believed Ypolito was armed and struck him out of self-defense. ${ }^{207}$

While the true grounds for his dismissal are unclear, Ypolito's allegation suggests the farmer was looking to employ only workers most vulnerable to exploitation. With his resident status, Ypolito had rights that were unavailable to undocumented workers and did not have the threat of deportation to discourage him from calling out employer abuse. As he had spent years in the United States and had gone through the process of gaining residency status, Ypolito would have had a much better understanding of the legal and judicial systems of the United States than the average undocumented migrant worker. It is quite possible that Fields was looking to dismiss to Ypolito and others with residency status in order to have a workforce comprised exclusively of workers who would be less likely to challenge his treatment of them.

According to Robert Olmos, work conditions for farm workers were exceptionally bad in Washington County compared with the rest of the state in the mid-1980s. "Strawberry field hands are getting 10 cents a pound on county farms, compared with about 15 cents a pound on farms in the Willamette Valley."208 Michael Dale, the director of Oregon Legal Service's farm worker program: Has received reports of visitors to local migrant labor camps being removed from the premises by persons connected with the farm

\footnotetext{
207 James Mayer, “Jury Selection Starts in Assault Trial," Oregonian, December 15, 1982, 25. James Mayer, "Wage Dispute Said Cause of Farm Worker Assault," Oregonian, December 16, 1982, 101.

208 Robert Olmos, “County Farm Labor Progress Seen as Lagging," Oregonian, July 17, 1986, 1.
} 
operations. In some cases, farm workers have been threatened with violence or physically restrained as they made moves to leave a camp. Those situations are not found as frequently in other parts of the state. 209

However vulnerable undocumented migrant workers were in Washington County, they were not without recourse. In 1986, Tankersley Farms agreed to pay a $\$ 26,000$ settlement to fifty-two Guatemalan and Mexican farm workers to settle a suit they brought alleging labor violations. Frank H. Tankersley, Iris G. Tankersley, Gary G. Tankersley, and Bobby F. Tankersley were named as defendants for the family. Also named as defendants were the Californian Rafael Diaz and the Guatemalan Tommy Hasso, two labor contractors who recruited workers from Guatemala on unfulfilled promises of high wages and decent living conditions. The two contractors "were not licensed, as required by law, and failed to provide written disclosure about the wages and working conditions to the workers they recruited."210 Oregon Legal Services' Ken Pallack, who filed the suit, explained that despite the undocumented status of the workers "they're still entitled to be paid for whatever work they do. They're not slaves.... They can sue as long as they're human beings and they've worked and should be paid."211 The farm's recruitment practices brought additional legal proceedings and criminal charges. Gary Tankersley, the son of Frank and Iris Tankersley who owned the farm, pled guilty to "one count of conspiracy, smuggling, and harboring illegal aliens and one count of

\footnotetext{
209 Ibid.

210 Joan Laatz, “Farm Pays \$26,000 Settlement,” Oregonian, July 17, 1986, 42. 211 Ibid.
} 
maintaining substandard housing conditions for farm workers." 212 He was fined $\$ 100,000$ and sentenced to one year in prison and five years of probation. ${ }^{213}$

This case exemplifies that Guatemalan workers were not merely "pushed" out of their country by civil war; they were also "pulled" to Washington County by the false promises of farm owners and recruiters. The pressure to pull in these Central American workers was likely intensified by the shortage of returning migrant workers-caused in part by the unwillingness of county farm owners and operators to raise wages. The migrant labor workforce in the county had largely shifted from tejanos and other Mexican Americans to Mexican nationals and Central Americans by the 1980s, as many with citizenship were able to transition to work opportunities that were better paying and less physically demanding than agricultural work. The practice of using false promises to attract marginalized farmworker families remained largely the same.

Ronald Tankersley, the sole defendant in the 1971 suit explored in chapter I, was not a defendant in the case summarized above, but he continued to run into legal troubles. ${ }^{214}$ In 1978, two workers brought a class-action lawsuit against him

212 John Painter Jr., "Oregon Farm Manager Admits Alien-Smuggling Conspiracy," Oregonian, February 17, 1988, A01.

213 John Painter Jr., "Farmer Sentenced to Prison," Oregonian, May 21, 1988, D01.

214 Ronald Tankersley owned and operated Tankersley's Spanish American Berry Farms in North Plains, Oregon. The Tankersleys named as defendants in the case ending in the 1986 settlement owned or worked for Tankersley Farms outside of North Plains. An obituary for Ronald Tankersley from 2011 lists a Bob and a Bobby Tankersley as his brothers and a Gary Tankersley as his cousin. It is not clear if one of the brothers is the same Bobby Tankersley or if the cousin is the same Gary Tankersley named as defendants in the lawsuit of 1985/1986 against Tankersley Farms. "Ronald Paul Tankersley," Hillsboro Argus Obituaries, August 2, 2011, Online at 
alleging that their wages and living conditions did not match what had been promised. In 1988, he faced another class-action lawsuit from eighteen cannery workers employed at his farm. Tankersley settled this suit, paying $\$ 32,889$ directly to the workers and $\$ 18,900$ to their lawyers. In 1990 , Tankersley was fined $\$ 30,650$ by the Oregon Occupational Safety and Health Division for the poor conditions of the bathrooms for workers. The fine was, at that time, the second largest levied by the division. In 1992, Tankersley paid $\$ 185,000$ to settle a class-action suit brought by Oregon Legal Services, Corp. on behalf of more than 125 farmworkers. The settlement also provided for a court-appointed monitor to ensure that Tankersley did not commit subsequent violations. ${ }^{215}$

That Ronald Tankersley was involved in so many different cases suggests that the punishments meted out to county farm owners were insufficient to deter them from underpaying workers and providing substandard living conditions for them and their families. Other county farm owners and operators may also have found it more profitable to risk fines and settlements than to invest in adequate living conditions for workers and pay workers at least minimum wage.

Recognizing the need to provide more and better housing for the migrant population, in 1981 the Housing Development Corp. of Washington County began to build townhouse apartments in Forest Grove and Hillsboro. The apartments were to be constructed for migrant families as well as low-income and handicapped

http://www.oregonlive.com/argus/index.ssf/2011/08/ronald_paul_tankersley.htm l, accessed March 4, 2014.

215 George Rede, "Farmowner Agrees to Pay $\$ 185,000$ to Migrant Workers," Oregonian, June 24, 1992, C04. 
individuals who were without housing. In a move echoing the efforts of the Cornelius City Council that delayed the construction of the new facility for Centro Cultural as addressed in chapter I, the Hillsboro City Council asserted that the Housing Development Corp. needed to apply for a conditional use designation because migrants would only occupy the units seasonally. The Housing Development Corp. alleged discrimination. Oregon's Land Use Board of Appeals overturned the city's decision, finding that the council was in violation of its own ordinance, which allowed construction to proceed. ${ }^{216}$ Roughly sixty Forest Grove residents protested the proposed housing project at a city council meeting, but the city's planning commission determined that the project did not require a conditional-use permit. This allowed construction to continue. 217

Sister Ina Marie Nosack, who worked at St. Alexander Parish from 1984 to 1996, remembered the poor treatment of migrants during this period. "They were so mistreated that it was just, it was wonderful to do anything you could to help them. And, they came expecting so much and were told that they'd have housing and, and work and instead they were just dumped off at the corner and left to find their own place."218 During the summers, Nosack visited the migrant camps to deliver

216 Diane Lund, "Migrant Worker Housing Projects to be Discussed," Oregonian, August 20, 1981, 36. Diane Lund, "Decision Reversed on Housing Permit," Oregonian, April 4, 1982, 62.

217 Diane Lund, "Forest Grove Residents Protest Migrant Housing Proposal," Oregonian, September 22, 1981, 52. "Suburban Roundup," Oregonian, October 27, 1981, 53.

218 Nosack interview, May 9, 2013. 
food and clothing. St. Alexander Parish provided assistance to twenty of the forty camps in the area. ${ }^{219}$

Nosack recalled a variety of living conditions at the migrant camps. "Roy Malinsky had wonderful camps. He even put air-conditioning in. He built new cabins.... For the most part I'd say the camps weren't all that bad. There were a few that really needed-Blue Camp was always the real bad one ... but that was the one that took anybody in.... For the most part they had a decent cabin and they had a place to cook, but as more people came there was just too many."220

Nosack highlighted that, "I lived in Peru and so I was used to very rough things." 221 In Peru she had worked with an impoverished community in the Amazon, and her evaluation of the camps was partially made in comparison to the conditions there. ${ }^{222}$ As a nun who had taken a lifelong vow of poverty, and who had lived in trying conditions in Peru and in humble quarters upon returning to the United States, Nosack was not inclined to fault the camps for their lack of conveniences. She also did not fault owners for failing to construct more housing, even though they likely had anticipated the size of the workforce needed and hired more workers than they could suitably house. Still, her observations of camps in the 1980s and 1990s suggested that conditions in some camps had improved from when the families of the tejano narrators arrived in the 1960s. Evangelina Sanchez noticed upon visiting the camps in 2013 how conditions had changed: “There're families and

219 Ibid. Nosack could not immediately recall the name of the other organization responsible for assisting the other twenty camps.

220 Ibid.

221 Ibid.

222 Ibid. 
their cabins that would now be considered luxurious because they have bathrooms in there and everything and kitchens. But not before, it was just one room."223

Conditions did not improve in similar fashion in all camps, however. In 1998, Alex Pulaski reported on the conditions of Oregon migrant camps, the lack of regular inspections of the camps by the Oregon Occupational Safety and Health Division, and the failure of state agencies to hold farm owners accountable for violations. Pulaski wrote that state records indicated that the registered farm labor camps, totaling 373 at the time of writing, were only inspected once every seventeen years on average, and that numbers of unregistered camps operated without inspection. Most camps were not in good condition:

Conditions in hundreds of camps range from neat and serviceable to crude and barely tolerable to revolting. The most recent comprehensive survey of farm worker housing was done in 1991. It indicated that about 4 percent of Oregon's registered camps were in very poor shape, that 8 percent would meet all of the state's inspection criteria and that the remainder were somewhere in between. ${ }^{224}$

Oregon Occupational Safety and Health Division issued two fines to Lazaro Ruiz, the operator of Campo Azul or Blue Camp, which Nosack spoke about in a negative fashion-one in 1995 for $\$ 20,300$ and one in 1997 for $\$ 10,500$-for safety and health violations. Ruiz was able to keep the camp open despite the existing

223 Sanchez interview, August 2, 2013.

${ }^{224}$ Alex Pulaski, "Hovels for the Harvest: Lack of Farm Checks Feeds Camp Squalor," Oregonian, July 19, 1998, A01. 
unpaid fines and the threat of new fines being imposed on him. ${ }^{225}$ Campo Azul made the news again in 2002 and was described as "notorious for its health and safety violations."226 A woman who helped out with religious services at migrant camps, and who favorably described conditions in most of the other camps, expressed surprise and disgust at the camp's lack of indoor plumbing and overall poor condition. ${ }^{227}$

Most county camp owners and operators made improvements to migrant living facilities in the latter decades of the twentieth century. Apartment complexes built in Forest Grove and Hillsboro in the early 1980s offered other residential opportunities for migrant families. Through the 1970s, 1980s, 1990s, and early 2000s, though, many migrants lived in substandard conditions, exposed to unhygienic and unsafe conditions daily.

As she distributed food and clothing, was fluent in Spanish, and provided other types of assistance to individual families, Sister Ina Marie Nosack, called $L a$ Madre, quickly became known in the camps after starting her work in 1984. Nosack would often visit the camps unaccompanied. "They were so good I never, ever felt afraid, you know. They respected me."228 During the off-season, Nosack visited with families who had settled year-round, helped them with childcare, and taught religious instruction to children at the parish in the afternoon. ${ }^{229}$

\footnotetext{
225 Ibid.

226 Laura Gunderson, "Washington County Studies Chance of Buying Troubled Migrant Camp," Oregonian, December 5, 2002, B01.

227 Ibid.

228 Nosack interview, May 9, 2013.

229 Ibid.
} 
While some non-Latinos at the parish did not approve of assisting Mexican and Central American migrants, most were supportive. "They [St. Alexander Parish] didn't have a very big Anglo community at all. But the ones that were there wanted so much to welcome the Hispanics and to be, have them be part of the community. There were a few who hung back, but for the most part they really wanted to join." “Sometimes our Anglo people [at the parish] didn't approve of what I did, and they let me know it, but they were few and far between."230

Even some of the individuals who provided material assistance, however, expressed prejudice and misgivings about the migrants. On one occasion, Nosack drove to a farm to pick up some donated apples, accompanied by a fourth-grade girl. Nosack was caring for the girl as her parents were in Mexico attending a funeral. "When this lady saw me drive in she gave me the apples and then turned to me and she said 'Don't you ever come on this place again with one of them in your car.'”231 The parish father later explained to Nosack that the woman was mentally unstable, but Nosack's inclusion of the story suggested that the reaction was indicative of the negative attitudes and prejudices harbored by some: "You met people like that sometimes."232

Nosack recalled helping with a program that fostered community and friendship between migrants and area residents. "We started a program of adopting a camp. We got the different churches, not just Catholic churches but any churches

\footnotetext{
230 Ibid.

231 Ibid.

232 Ibid.
} 
that wanted to take part." 233 Church member families provided assistance to the camps, and occasionally socialized with the migrant families. Community Action also served as a partner in the program. "Maybe twice during the summer, they'll have a big barbecue with all of the people out there... just getting to know the people, that's been a real good thing." 234 Nosack talked to a group of women from Portland's Pius X Parish about the best way to help their camp. "They would get the parish to get behind whatever they were doing, whether they were going to collect food or clothing ... they built a basketball court in one of them, it was really nice."235

Through her connections with local business owners, Nosack located work opportunities for many recently arrived migrants. She recalled that many of the single migrant men, and at least one single mother who braved the border crossing with her children, found work at the nurseries:

After the berries [strawberry season] the nurseries would hire the guys. And many times at five o'clock in the morning I would take a group of men out to the nurseries where I knew they needed help. I would call ahead and ask if they were hiring and say, 'I've got some good workers for you.' [Laughs] They all knew me.236

While Nosack was essentially playing the role of a recruiter, she was doing so to improve the well being of workers and their families and was not afraid of confronting employers regarding exploitation. While assisting parents of newborn triplets, she realized that the non-citizen father made significantly less money as a

\footnotetext{
233 Ibid.

234 Ibid.

235 Ibid.

236 Ibid.
} 
nursery foreman than a white, non-Latino employee with the same job. Nosack called the home of the nursery owner and demanded that the owner's wife explain to her why they were keeping the Mexican foreman at such a low wage. The wife promised to "do something about it," though in the end the foreman received a paltry Christmas bonus equivalent to a "five cent raise in his salary. I was so angry."237

\section{"Over 3,000 applicants for residency"}

The 1986 Immigration Reform and Control Act (IRCA) provided a path to residency for some undocumented migrants. Nationally, roughly 2.7 million migrants were eventually granted legal status under the act, with Mexican migrants constituting 74 percent and Central Americans constituting 21 percent of applicants. ${ }^{238}$ Nosack helped migrants through the application process in 1988:

The last year that people could get papers to be here officially.... Father Dave [Zegar, of St. Alexander Parish] hired a college graduate ... she came then to work at our place just on doing the paperwork for the immigration office. And I helped during what free time I would have, I'd go in and help her. And people would line up in the morning and they'd be there late at night. We'd be there until almost ten o'clock sometimes doing this paperwork for them.... During that year we did over 3,000 applicants for residency here. ${ }^{239}$ The legislation had a significant impact on the movement and settlement patterns of migrants. While Mexican migration had become a

37 Ibid.

238 Gonzales-Berry and Mendoza, Mexicanos in Oregon, 105 - 106.

239 Nosack interview, May 9, 2013. 
"systematic, circular phenomenon" 240 by the 1980 s, the passage of the IRCA and other events of the decade compelled many migrants to reconsider their transnational living and working arrangements. Articles from the Oregonian highlighted the continuing influx of migrants, as well as the changing social conditions and the rise of anti-immigration rhetoric and deportation threats in the 1980s. The IRCA, intended to curb further undocumented immigration, had the unanticipated effect of prompting additional immigration from Mexico and Latin America. Many migrants who had been granted amnesty or a path to residency sent for their family members to join them immediately instead of waiting on the uncertain visa application process. They feared that the border might become permanently closed and that they would be unable to live with their loved ones. ${ }^{241}$

The act also made it illegal for employers to knowingly hire undocumented migrants. In a climate of increased uncertainty regarding seasonal work opportunities and increased difficulty associated with crossing the border in the late 1980s and early 1990s, many workers and families residing seasonally in Washington County and elsewhere in the United States chose to abandon cyclical migration and settle permanently north of the border. As 1988 was the last year in which individuals and families could apply for residency or amnesty under IRCA, that growing

240 Gonzales-Berry and Mendoza, Mexicanos in Oregon, 102. 241 Ibid., 106. 
season saw the most dramatic increase in the number of migrants from Mexico and Latin America. ${ }^{242}$

Washington County felt the strains of the sudden influx of immigrants in 1988. The Oregonian reported in July 1988 that the state was hosting 35,000 migrants, up 10,000 from the year before. ${ }^{243}$ Farmers in Washington County and much of the rest of the state had trouble finding enough help during many growing seasons. Uncertainty over immigration laws and restriction discouraged many international migrants from entering the United States for the 1987 season, and the resulting labor shortage caused nearly 20 percent of the state's 93-million pound strawberry crop to go unpicked. In 1988, by contrast, the number of migrants was far in excess of the number of work positions available, migrant camps filled beyond capacity, and aid organizations found their resources stretched thin from supporting the expanded population of immigrants. "Farmers, besieged by migrant laborers seeking work and shelter in their camps, are turning to agencies, such as Centro Cultural, Housing Services Inc., and the Salvation Army, to get food, clothing, and blankets."244 Virginia Garcia Memorial Health Center struggled to serve patients as the number of people seeking medical care and services more than doubled over the spring and summer. ${ }^{245}$

\footnotetext{
242 Ibid., $104-107$.

243 Nancy McCarthy, "Lure of Jobs, Food, Shelter Brought Migrants North," Oregonian, July 10, 1988, C08.

244 Nancy McCarthy, "Influx of Field Laborers Swamps Agencies," Oregonian, June 5, 1988, A01.

245 Ibid.
} 
Many Mexicans and other Latinos gambled on an uncertain future in the United States to join family members there permanently. While 1988 saw the most dramatic increase in migration from Mexico owing to the changing immigration laws, heavy migration continued to Oregon and Washington County over the following years. Many of the arrivals to Washington County, unsure of the difficulty of subsequent border crossings, made plans to reside in the county on a permanent basis. 


\section{Chapter III Mexican Immigrants in the 1990s, 2000s, and 2010s}

\section{Narrators introduced in this chapter:}

- Ariadna Covarrubias Ornelas was born in 1992 in the Mexican state of Michoacán and lived there until age 10. At that time her family relocated to Washington County to join her father, who had been working in the area for years. She earned an associate degree, and planned to eventually complete a Ph.D. in biochemistry. She was living in Cornelius at the time of the interview.

- Eduardo Corona was born near Mexico City, and graduated from Mexico City's Universidad Autónoma Metropolitana (Metropolitan Autonomous University). After years of work in Mexico, he moved to California in 1999 to work for a U.S.-based company with multinational operations. A subsequent work opportunity brought him and his family to Beaverton, Oregon. A work transfer to Guadalajara had the family living in Mexico for several years before their return to Beaverton, where they have resided since 2010.

- "Giores" was born in Colima, Mexico, and spent most of his adult life in Mexico City before relocating to the United States. Giores found life in Mexico City fast paced, uncertain, and stressful. After working at a number of different occupations there he left Mexico. A family connection brought him to Cornelius, Oregon, in 2007. This interview was conducted in Spanish.

This chapter explores the factors that have prompted immigration from

Mexico and elsewhere in Latin America since the early 1990s. It examines Mexican immigrant narrator experiences of discrimination, their work and educational experiences, and their overall impressions of life in Oregon and the county. This chapter utilizes both tejano and Mexican immigrant narrator perceptions on the nature of community among Latinos in Washington County to assess how community has changed since the 1960s. I argue that the early settlers, most of them tejanos, positively influenced social, educational, and career opportunities for subsequent migrants through their vocational and community-building roles. I also utilize narrator opinions on cultural and linguistic identity to argue that continuing 
immigration and the growth of the Latino population have furthered the important trend of cultural replenishment for residents.

\section{Reasons to relocate}

By increasing restrictions on the movement and employability of undocumented migrants, and offering a path to resident status for some, the IRCA of 1986 was intended to resolve the issues associated with undocumented immigration to the United States. The act was designed in part to allow the United States to participate in increased international trade through the North Atlantic Free Trade Agreement (NAFTA) on favorable terms and protect the nation from an influx of immigrants who had lost their jobs due to the international effects of free trade. 246

Backers of NAFTA argued that free trade would encourage economic growth from Mexico and increase the rate of Mexican imports. NAFTA did not affect the Mexican economy as its supporters had predicted, however. Free trade allowed for the importation of agricultural goods from the United States (U.S. farms were larger, more mechanized operations than the average Mexican farm, and could offer agricultural products at lower prices). In Understanding NAFTA: Mexico, Free Trade, and the New North America, journalist William A. Orne, Jr. wrote that per capita incomes in Mexico declined from just over $\$ 4,000$ at the time the treaty was introduced in January 1994 to $\$ 2,600$ in January 1995.247 Loss of agricultural profits

246 Gonzales-Berry and Mendoza, Mexicanos in Oregon, 106.

247 William A. Orme, Jr., Understanding NAFTA: Mexico, Free Trade, and the New North America (Austin: University of Texas Press, 1996), xi. 
and jobs contributed to slow and faltering rates of economic growth in Mexico over subsequent years. ${ }^{248}$

A poorly performing Mexican economy, coupled with rapid population growth, resulted in reduced work opportunities for many Mexicans. The population grew from nearly 67 million in 1980, to just over 81 million in 1990, to just shy of 97.5 million in 2000.249 People from all over Mexico found job prospects dwindling. Many, like the narrators featured in this chapter, decided to relocate to the United States for work. Gonzales-Berry and Mendoza wrote:

Oregon's Mexican population increased 144 percent during the 1990s, and the Hispanic workforce grew 269 percent from 1990 to 2003, according to the Oregon Employment Department. The natural growth of the tejano settler population certainly accounts for part of this population increase in Oregon, but the spike in numbers can also be attributed to the enhanced employment opportunities in agricultural enterprises and other industries such as hospitality, reforestation, construction, light manufacturing, and transportation. 250

Washington County experienced an even faster rate of growth of the Latino population than the state overall during the 1990s, with the population more than tripling between 1990 and 2000. The influx of individuals and families from Mexico and elsewhere in Latin America considerably altered the size and social dynamics of the Spanish-speaking population in the county.

\footnotetext{
248 Gonzales-Berry and Mendoza, Mexicanos in Oregon, 113 - 114.

249 National Institute of Statistics and Geography (INEGI), accessed through Google Public Data Explorer, accessed online February 21, 2014. 250 Gonzales-Berry and Mendoza, Mexicanos in Oregon, 114 - 115.
} 
In 1990 , the Hispanic population of the county was recorded as 14,680 out of a total county population of 315,470 . In 2000 , the Hispanic population of the county was 50,420 out of a total population of $447,980 .{ }^{251}$ The figure for the Hispanic population in 2000 , more than triple that of 1990 , showed a rate of population growth far in excess from what census officials had projected. ${ }^{252}$ In 2010 , the total Hispanic or Latino population of the county was 83,810 , of a total population of 531,610.253 Throughout this two-decade period, slightly over three-quarters of county Latinos identified as Mexican.254

While the narrators who relocated from Mexico in the 1990s and 2000s migrated for reasons similar to those of the tejanos in the 1960s, upon arrival they took advantage of assistance and educational opportunities that were not available to the first settling families. Giores was born in Colima, a small Mexican state on the Pacific coast, but moved to Mexico City as a young adult; increased internal migration to urban areas was precipitated by economic stagnation in Mexico. Giores, who worked as a taxi driver and in a number of other occupations in Mexico City, remembered the challenges of working life in the metropolis. "Es muy, muy complicada vida. Es muy rápida, es muy alocada, estresante. Debe estar uno luchando día con día para, para salir adelante.-It's a very, very complicated life. It's very fast,

2512013 State Profile Oregon, Woods \& Poole Economics, 358.

252 Chuang, "Diversity Comes to Oregon," Oregonian, March 18, 2001.

2532013 State Profile Oregon, Woods \& Poole Economics, 358. 254 "Washington County, Oregon," U.S. Census Bureau, 2010 Census. Online at http://factfinder2.census.gov/faces/tableservices/jsf/pages/productview.xhtml?pi d=DEC_10_SF1_QTP10, accessed April 22, 2014. 1990 Census of Population: General Population Characteristics of Oregon, U.S. Census Bureau, (Washington, D.C.: U.S. Government Printing Office, 1992), 296, table 79. 
it's very wild, stressful. One must fight day by day to get by." 255 In 2007, Giores decided to move to the United States in search of better work opportunities: "Todos tenemos la idea de alcanzar un sueño Americano.-We all have the idea of achieving an American dream."256

A family connection led Giores to settle in Cornelius. After he arrived, Giores went to Centro Cultural and to St. Alexander Parish for assistance. He recalled being helped by other migrants, "personas en su misma situación que le van a uno informando, diciendo como están las cosas._-people in the same situation that would inform one, explaining how things are."257

Laura Gamboa, who relocated to Oregon in 1990, spoke in similar terms as Giores about the ways that people in Mexico perceived the United States:

Siempre he sabido en Cuautla que Estados Unidos es el país de las oportunidades, y mucha gente emigraba para acá porque, pues, pagan mejor y la gente quiere tener una mejor estabilidad económica. In Cuautla I have always known that United States is the country of opportunities, and many people emigrate because they pay better and people want to have better economic stability. ${ }^{258}$

As mentioned in chapter II, Laura Gamboa's family found that more and more vendors were competing with their family's refreshment stand for business. With opportunities scarce in Cuautla, people looked to the United States for work. Gamboa moved to Oregon following her husband and her mother. These two

\footnotetext{
255 Oral history interview with Giores, October 3, 2013, Hillsboro, Oreg., in author's possession and in the possession of the Washington County Museum.

256 Ibid.

257 Ibid.

258 Laura Gamboa interview, October 17, 2013.
} 
initially relocated from Cuautla to Madera, California. After spending six months there, they heard about the work opportunities in Oregon for the strawberry harvest. They decided to stay in Oregon after the harvest ended. With her two young daughters, Gamboa left Mexico to meet her husband and mother and settle in Washington County. ${ }^{259}$

Like Laura Gamboa, Ariadna Covarrubias Ornelas moved to the county to be reunited with family members. During her childhood years in Mexico, her father was working in Oregon to financially support the family, and she would see him when he was able to visit "maybe once every year or six months.... I would talk to him every so often, maybe once a month over the phone." 260 Interacting with her father when he did return home presented challenges. "It was difficult when he would go visit because I wasn't used to him being around and telling me what to do. Everything had been my mom.... She was the authority figure I looked up to."261

Covarrubias Ornelas remembered one phone call when her father asked if she and the family would like to live with him in Oregon. "I wanted to live with him because I had never really had my father around and I wanted to see how that felt."262 Covarrubias Ornelas, her younger brother, and her mother left Mexico and moved to Cornelius. "I didn't miss home because I had my parents. I had my brother.

\footnotetext{
259 Ibid.

260 Oral history interview with Ariadna Covarrubias Ornelas, June 12, 2013, Cornelius, Oreg., in author's possession and in the possession of the Washington County Museum.

261 Ibid.

262 Ibid.
} 
I didn't feel overwhelmed because I had them and it was fine as long as I was with them."263

Two of the Mexican immigrant narrators came from professional backgrounds, and left behind fairly comfortable lives in Mexico. Their decisions to move to Washington County were comparable to Ruben Contreras's decision to work as a bracero, and his subsequent permanent relocation to Yamhill County, in that these individuals migrated for reasons other than immediate economic pressures. Eduardo Corona earned a degree from Universidad Autónoma Metropolitana in Mexico City, where he majored in business administration. Work first brought him to the United States in 1999, when he moved to Riverside, California, while working for a recycling company with multinational operations. Subsequent work opportunities for him and his wife led them to settle the family in Beaverton. For their most recent relocation to Oregon-the family had resided for a time in Washington County before living in Guadalajara, Mexico, for several years due to work transfers - in 2010 Corona quit his job in Guadalajara to accompany his children and his wife, whose employer had transferred her back to Oregon. ${ }^{264}$ Arturo Villaseñor also moved to Washington County after obtaining a university degree and acquiring professional experience in Mexico. Villaseñor studied at Mexico City's Instituto Politécnico Nacional, earning a bachelor's degree in physics and mathematics and his civil engineer title. A curiosity about living abroad,

\footnotetext{
263 Ibid.

264 Oral history interview with Eduardo Corona, September 11, 2013, Hillsboro, Oreg., in author's possession and in the possession of the Washington County Museum.
} 
changing social and political conditions in Mexico, and a family connection in Washington County led Villaseñor and his wife to move the family to Oregon. Villaseñor pointed to the 2000 election that saw Vicente Fox Quesada assume the Mexican presidency as an event that encouraged them to relocate outside of Mexico: We used to have a party called PRI (Institutional Revolutionary Party) on the power; it was the party that governed Mexico for more than 70 years. I was finishing one work in Mexico City too and then I saw this approaching change, with a new presidency, another political party, the PAN (a right-wing party). So, I thought, "maybe this is the time to move to another place." I was always curious to live in another country-maybe Europe, maybe Canada, maybe the U.S. And, on that particular time I say to myself: "This is a breaking point, the time to decide to see another culture, to live something different."265 Villaseñor was careful to clarify that, though the relocation to Washington County was not an easy one, his decision to emigrate was different than the decision that many Mexicans and other Latinos were forced to make. As a civil engineer, his family was not compelled by economic necessity to leave Mexico. "For me it was more ... to know another culture, to be in another place. It was also like a challenge to try to adapt.... We wanted to taste another culture."266 Originally planning on moving to Toronto, Canada, Villaseñor and the family visited his wife's relatives in the United States. After visiting her cousin in Hillsboro, the family decided to postpone a move to Canada to try life in Oregon.

\footnotetext{
265 Villaseñor interview, November 11, 2013. 266 Ibid.
} 
A lack of financial history or credit in the United States severely limited housing options for the Villaseñor family. "We are Christians from the Assemblies of God [a Pentecostal denomination], and some friends from there offered their home to us. And in the very beginning we lived with our friends." 267 Once the family established some credit, they were able to rent a house. ${ }^{268}$

Mexico is a nation that is far from religiously homogenous, and ethnic Mexicans, like Villaseñor, and other Latinos in the United States hold an increasing diversity of religious beliefs and affiliations. The Catholic Church provided an important role in aiding migrant workers and in introducing many of the early settling tejano families to one another, and some of the narrators identified strongly with the Catholic Church in their interviews, but Villaseñor found community and assistance through affiliation with a different Christian denomination. Ethnic Mexicans and other Latinos of a variety of religious backgrounds relocated to Oregon and formed community through their faith networks.

In 1995, Fiona Ortiz reported for the Oregonian on the thousands of Latinos in Oregon that attended evangelical or other protestant churches. Some churches added Spanish-language services in addition to their services in English; others were formed to serve Spanish speakers. Preachers, or pastors, and churchgoers were comprised both of those who had left the Catholic traditions they were raised with and those who were raised in Protestant faiths in the United States or in home

267 Villaseñor interview, November 11, 2013. 268 Ibid. 
communities in Latin America. ${ }^{269}$ While most Latinos living in Washington County continued to identify with Catholicism, an increasing number identified with other denominations and faith traditions. These individuals and families formed networks of mutual assistance and friendship along the lines of their shared beliefs.

\section{“Del campo ya pasamos a otras cosas-From the field we move on to other}

\section{things"}

Narrators and their families came from different educational and career backgrounds in Mexico, and they found different types of work opportunities after arriving in Washington County. Those narrators and narrator families who moved from Mexico out of economic necessity began working in Washington County in agriculture or in other unskilled/entry-level positions. Ariadna Covarrubias Ornelas's father worked labor-intensive jobs since first coming to Oregon in the early 1990s, and her mother entered the workforce in a similar capacity:

The first few years he was living in Oregon he did kind of like plant nursery or picking fruit I think. Now for more than ten years he's been working at fixing the pallets used for transportation. My mom, when she first arrived here she would babysit for a cousin and an acquaintance. Then about six, seven years ago she started working at [a] plant nursery and that's where she's been since. ${ }^{270}$

Farm work was Giores's first occupation after leaving Mexico. "Inicialmente, yo creo que como todos empezamos en el campo. Del campo ya pasamos a otras cosas.-Initially, I believe like everyone we begin in the field. From the field we

269 Fiona M. Ortiz, “Born-Again Hispanics,” Oregonian, November 26, 1995, L01. 270 Covarrubias Ornelas interview, June 12, 2013. 
move on to other things." ${ }^{271}$ Giores next worked in landscaping before beginning work as a painter. ${ }^{272}$

Laura Gamboa relocated to Washington County as a young mother. Her first job was ironing shirts at a dry cleaner.

Después de allí, me-busqué como mi hija seguir estudiando y conocí el programa de Oregon Child Development Coalition, y allí me ofrecieron trabajo.

After that, I-I looked, like my daughter, to keep studying and I learned about the program of Oregon Child Development Coalition, and there they offered me a job. ${ }^{273}$

Gamboa began working as a teacher's assistant. Seven years later, she received her Child Development Association accreditation and worked as a teacher for twelve years until a change in licensing requirements forced her to return to work as a teacher's assistant. 274

The two narrators who had earned college degrees in Mexico found new career paths in Washington County. After volunteering at KBOO, Portland's community-oriented radio station featuring Spanish and English language programming, upon returning to Oregon in 2010, Eduardo Corona found an opportunity to direct the micro-business development program for Adelante Mujeres. Bridget Cooke and Sister Barbara Raymond founded the organization in 2002 to serve and empower Latina women in Washington County. The microbusiness program provided instruction and resources to individuals looking to open

271 Giores interview, October 3, 2013.

272 Ibid.

${ }^{273}$ Laura Gamboa interview, October 17, 2013.

${ }^{274}$ Ibid. 
their own small businesses. ${ }^{275}$ Adelante Mujeres mainly serves Latina women, but this program was open to men and women and the classes were evenly divided between the genders.

While Corona made a number of sacrifices in moving to Washington County - "it's not easy giving up your things, all your stuff, your car . . . and start all over again"276_his educational background and professional experience helped him to find work that utilized his talents and that he considered rewarding. "It's a total different experience than working in front of my computer ... just doing imports, exports, or bookkeeping or financing. So it's very, very different working with people. It's a great opportunity. I'm so happy."277 Arturo Villaseñor recalled the challenges he faced in determining a new career path in Washington County:

In the very beginning it was really tough because I didn't handle the language very well. As you see I don't really speak English. And even as a civil engineer, was too hard to find a place to work like an engineer. I met some friends from the Mexican consulate that help to find one job, they help to figure it out what kind of sort of opportunity I could find for me. I even make a good friend in the architecture field, an architect from Mexico. And I discovered that NAFTA was not a good treaty, that it was really good for people with a lot of money, with big capitals, but not for a professional like me, even with my experience on the field. So I was trying to find some other ways to make my living and then I started working as a volunteer. ... I said,

275 “History \& Values," Adelante Mujeres, http://www.adelantemujeres.org/historyvalues/, accessed March 11, 2014.

276 Corona interview, September 11, 2013.

277 Ibid. 
"well maybe I can do something different than I used to do there in Mexico."278

After moving to Hillsboro, Villaseñor began preparing for the GED by taking preparatory classes at Community Action. As he had a university degree and experience as a civil engineer in Mexico, he was able to pass the exam without too much difficulty. His tutor noticed that he was excelling in the GED preparatory program, and encouraged him to help her with the other students, "I started working with people that need to learn more about math, Spanish."279

Villaseñor also began volunteering at Centro Cultural along with his wife, and was eventually offered a job teaching computer classes and Spanish classes. After working at Centro and then working at another job translating educational texts into Spanish, Villaseñor was offered a position at Adelante Mujeres. At the time of our interview in late 2013, he served as an instructor of Spanish, math, and computer classes and was the coordinator of the organization's "Sabor Color" ("Taste Color") program that provided instruction and resources to individuals looking to open their own food service businesses. "Right now Adelante Mujeres is mostly females from Mexico, or from other places that they don't have the education. Also some of them are victims of domestic violence, so they are the particular population that really, really need help and I love working with them. It's quite rewarding." 280 Villaseñor faced challenges in relocating to Washington County and had to change his career path, but he was able to apply his education and linguistic

278 Villaseñor interview, November 11, 2013.

${ }^{279}$ Ibid.

280 Ibid. 
and cultural background to instruct other Mexican and Latin American immigrants. $^{281}$

Expressing some dissatisfaction at her demotion and in having her weekly hours reduced, Laura Gamboa enrolled in the micro-business course taught by narrator Eduardo Corona to learn the skills to start her own business. She hoped to either open her own bilingual daycare or earn a license to start a restaurant cleaning service. "Me parece que es una buena oportunidad para que uno pueda ser su propio jefe y no dependas en patrón.-It seems to me a good opportunity to be one’s own boss and not depend on an employer."282

Giores was also attending the micro-business course at the time of our interview in late 2013. He opted not to discuss specific plans for his business, but hoped "conseguir una estabilidad mejor. ... Aquí en el Estados Unidos este-se te crean las oportunidades para conseguirlo. — to obtain better [financial] stability.... Here in the United States they create opportunities for you to succeed."283 Giores was proud of earning his GED after arriving in Washington County:

Después de tantos años que lo dejé pendiente en mi país de origen. Con eso me siento un poco más seguro y con los planes que quiero-o que queremos hacer, con mi familia, es este seguir avanzando y establecerte o consolidarte mejor.

After so many years that I left it [graduation] hanging in my home country. With that I feel a little more secure and with the plans that I

281 Ibid.

282 Laura Gamboa interview, October 17, 2013.

283 Giores interview, October 3, 2013. 
want—or that we want to do with my family is keep advancing and better establish ourselves. ${ }^{284}$

As an organization offering resources for the Latino population, Adelante Mujeres provided work opportunities for narrators Corona and Villaseñor and educational opportunities for narrators Gamboa and Giores.

\section{"It almost feels like everybody has their own group": community among}

\section{Latinos}

Decades of heavy immigration greatly altered the size and demographics of the ethnic Mexican and Latino populations of the county. Both tejano and Mexican immigrant narrators shared their current opinions on the presence or absence of an ethnically defined community. Some narrators talked about a distant or weak sense of community among Latinos, feeling that smaller social, cultural, and familial groups divided this population. Their reflections highlight the ways that changes to the size and demographics of the Latino population in the decades since the 1960s influenced the social nature of what was initially a tight-knit community. Ariadna Covarrubias Ornelas, who lived in Cornelius at the time of our interview, described the ethnic Mexican community as "distant. ... As to say that they're tightly knit I haven't experienced it-maybe because my parents don't really know how to connect with people in a community like that." ${ }^{285}$ Covarrubias Ornelas felt that community outside of the Catholic church they attended seemed lacking. "There's been times when I see-people I see at church I see outside of church and I

\footnotetext{
284 Ibid.

285 Covarrubias Ornelas interview, June 12, 2013.
} 
recognize them. I think I feel like they recognize me but it's just like-I don't know how to explain it."286

Eduardo Corona felt that family ties often superseded broader community ties among Latinos:

I used to say there's no Mexican without cousins, so people tend to develop strong family ties. And this is a little different than in other communities. We as Latinos tend to develop very strong family ties but not strong community ties.... We play together, we party together and we do a lot of things together but not as sense of community organization for doing things in an organized way. This we have to work [on].287

Giores, who lived in Cornelius, offered similar observations to those of Corona and Covarrubias Ornelas:

Yo la conozco a través de la iglesia, de los eventos que tiene la iglesia.... Ves en la comunidad por un lado unida, pero por otro lado-yo creo que unida por la iglesia, pero muy separada familiarmente. De familia a familia.

I know [the community of Cornelius] through the church, from the events that the church has.... You see in the community on one side united, but on the other side-I think united by the church, but very separated by family. From family to family. ${ }^{288}$

While Eduardo Corona and Giores spoke of a population that was divided along family lines, Evangelina Sanchez and Laura Gamboa spoke of a tendency of various migrant and immigrant groups to stick together according to their region of

\footnotetext{
286 Ibid.

287 Corona interview, September 11, 2013.

288 Giores interview, October 3, 2013.
} 
origin or country of origin. Evangelina Sanchez, elaborating on her perception that the cohesion of an initially tight-knight community had dissolved, stated:

There's not that sense of community anymore. It almost feels like everybody has their own group because so many other communities from Mexico have come here from Oaxaca, from Guadalajara, from Costa Rica, and it seems like everybody has their own community. 289 Laura Gamboa offered similar observations:

La gente que viene de Oaxaca-ellos cuando emigran para acá para Oregón casi siempre se vienen en grupos. ... Ellos sigan con sus tradiciones... remedios caseros para sus niños, las comidas, y las festividades que ellos festejan en su pueblo. También las personas que vienen de ... Yucatán. Y ellos también conservan sus tradiciones, y su comida, y su cultura. Les inculcan a sus niños-por ejemplo les hablen el dialecto que es otra lengua, no es español, es otra lengua que ellos quieren seguir conservando con sus niños.

The people from Oaxaca - when they emigrate here, to Oregon almost always they come in groups.... They continue their traditions ... home remedies for their children, [their] foods, and the festivities that they celebrate in their town. Also there are people that come from ... Yucatán. They also preserve their traditions, and their food, and their culture. They instill in their children-for example they speak a dialect that is another language, not Spanish, it's another language that they want to keep preserving with their children. ${ }^{290}$ Mexico has never been a culturally homogenous nation. In "Mass Media and Popular Culture in the Twentieth Century," historian Anne Rubenstein wrote: "Most Mexicans in 1940 lived in the countryside and small towns ... and thought of

289 Sanchez interview, August 2, 2013.

290 Laura Gamboa interview, October 17, 2013. 
themselves less as citizens than members of their small communities."291 Even as the rise of new communication technologies, mass marketing strategies, and the increasing urbanization of the country combined to create a national popular culture over subsequent decades, ${ }^{292}$ these developments did not erase distinct regional cultures and identities in Mexico.

That different parts of Mexico celebrate different holidays highlights the lasting importance of local or regional identity and culture. Ariadna Covarrubias Ornelas described how different regions gave importance to certain holidays and largely ignored others: “Cinco de Mayo is for Puebla. Independence Day is mostly the state of Mexico. It depends region to region and how each family wants to celebrate it."293 Covarrubias Ornelas's family celebrated neither of those holidays. For them, Mother's Day, celebrated on May 10, instead of on the second Sunday in May as done in the United States, was an important holiday. ${ }^{294}$ Rather than form community on national or pan-Latin American lines, in recent years many arriving Mexican and other Latino settlers to the county placed an emphasis on creating community with others from a more geographically limited region of origin, with only their family members, or, as examined earlier in the chapter, with others belonging to their place of worship or religious denomination.

291 Anne Rubenstein, "Mass Media and Popular Culture in the Twentieth Century," in The Oxford History of Mexico, edited by Michael C. Meyer and William H. Beezley (New York: Oxford University Press, 2000), 637.

292 Ibid.

293 Covarrubias Ornelas interview, June 12, 2013. 294 Ibid. 
Hector Hinojosa: “Cornelius is 50-50, I think 50 percent Hispanics now. It wasn't that at all. Back in the '60s there was probably 12, 14 families that were settled here. The rest were going back and forth. They were still active migrants."295 As the populations of ethnic Mexicans and other Latinos grew considerably in the cities and towns of the county, maintaining a close-knit community among all Latinos became impossible.

The members of the first settling tejano families struggled to accept the ways that community cohesion was challenged by the large-scale settlement of migrant families and the formation of smaller intra-ethnic communities. In certain respects, however, the initial community that the tejanos created in the late 1960s mirrored the intra-ethnic communities that formed in the 1980s, 1990s, and 2000s along the lines of shared faith or shared country or region of origin. Like those more recently formed Latino communities, members of the initial tejano settler community had more in common than just ethnicity. They were from the same geographic region of origin, and most were actively practicing Catholics. Mirroring the formation of communities that emerged within the county's growing Latino population in subsequent decades, community cohesion among the first settling families was facilitated by what they had in common beyond a shared linguistic and ethnic background.

\footnotetext{
295 Hinojosa interview, July 29, 2013. According to the U.S. Census Bureau, in 2010 50.1 percent of the population of Cornelius identified as Hispanic or Latino. "Cornelius city, Oregon," U.S. Census Bureau, 2010 Census, http://factfinder2.census.gov/faces/tableservices/jsf/pages/productview.xhtml?pi d=DEC_10_DP_DPDP1 accessed April 22, 2014.
} 
Many people relocating to Oregon from Central America and southern Mexico during and after the 1980s were of indigenous descent. They began to play an increasingly important role in agricultural work in the state. Writing for the Oregonian in 1995, Kate Taylor quoted Merced Flores, who oversaw migrant education for the Oregon Department of Education, on workers from Oaxaca. Many, though not all, migrants from Oaxaca were of indigenous descent.

[Workers] often find Oregon less threatening than California, because it is farther away from the border and immigration [officials].... People also find that there are a lot more jobs here. People hear of opportunities through their friends and relatives. That feeling that this is the land of opportunity still runs pretty deep. ${ }^{296}$ Writing in 2010, Gonzales-Berry and Mendoza cited estimates from researchers at Portland State University and the Oregon Law Center that people of indigenous backgrounds from Guatemala and Mexico comprised roughly 40 percent of Oregon's agricultural workforce. "These researchers identified twelve native languages on Oregon's farms."297 Most of the Mexican-born narrators recalled meeting people in Washington County who spoke an indigenous language. "Sometimes it makes it quite difficult because we need to teach in Spanish and then also with English,"298 Arturo Villaseñor said of instructing people who spoke one of these languages, rather than Spanish, as a first language. Laura Gamboa, who worked with migrant children during the summers as a teacher's assistant, recalled

\footnotetext{
296 Kate Taylor, “Oaxaca and Oregon,” Oregonian, April 23, 1995, L10. See also "Mixtecs in Oregon," Oregonian, February 13, 1994, A15. 297 Gonzales-Berry and Mendoza, Mexicanos in Oregon, 152 - 153. 298 Villaseñor interview, November 11, 2013.
} 
that the people from Oaxaca spoke "el dialecto que se llama Triqui, y en Yucatán está el dialecto Maya. En Guatemala, porque también hemos tenido niños de Guatemala, hablan el dialecto Q'anjobal.- the dialect called Triqui, in Yucatan they speak the Maya dialect. In Guatemala, because we also have had children from Guatemala, they speak the Q'anjobal dialect."299

For the 2010 census, 67,030 of the county's 83,270 (the census figure differs from the figure of 83,810 as provided by Woods \& Poole Economics) Latinos identified as Mexican, 5,207 as a Central American nationality (Guatemala leading this category with 2,935 residents), 2,375 as a South American nationality (Peru leading this category with 702 residents), 1,665 as Puerto Rican, 692 as Cuban, and 102 as Dominican (Dominican Republic), and 6,199 as "Other Hispanic or Latino."300 The ethnic Mexican population of the county grew by more than 50,000 between 1990 and 2010, and Mexicans (including a significant number of indigenous Mexicans) as a proportion of the county's Latino population grew from about threefourths to roughly four-fifths of the total. ${ }^{301}$ People from elsewhere in Latin America also continued to immigrate to Washington County in sizable and growing numbers.

Narrators noted the presence of people who had immigrated from elsewhere in Latin America. Giores said that in Cornelius: "He conocido gente de Guatemala, de Honduras, de El Salvador, de Cuba, y Puerto Rico.-I have met people from Guatemala,

299 Laura Gamboa interview, October 17, 2013.

300 "Washington County, Oregon," U.S. Census Bureau, 2010 Census, accessed online April 22, 2014.

301 Ibid. "Washington County, Oregon," U.S. Census Bureau, 2000 Census, online at http://factfinder2.census.gov/bkmk/table/1/en/DEC00_SF1/DP1/0500000U5410 67, accessed May 8, 2014. 1990 Census of Population: General Population Characteristics of Oregon, U.S. Census Bureau, 296, table 79. 
from Honduras, from El Salvador, from Cuba, and from Puerto Rico."302 While Mexican immigrant narrators did not automatically form close bonds with all Latinos they met, they did work with and befriend people who had relocated from other Latin American countries. Most of Villaseñor's students were Mexican, but there were also "some people from Argentina, Peru. I am working with people from Peru right now; I used to have one student from Panama."303 Eduardo Corona noted of his students, "we have Argentinean people. We have Peruvians, a lot of Peruvians, some Salvadorians and Guatemalan people also." "Most of my friends [who aren't Mexican] are Latinos from Argentina or Chile or Peru." ${ }^{304}$ Shared language, some cultural commonalities, and comparable migration experiences facilitated the formation of friendships among Washington County Latinos.

Evangelina Sanchez was teaching courses for foster parents at Portland State University:

I think one of the most pleasant things is that I don't only have people from Mexico now-which is again bringing us all together-I have people from Cuba, Puerto Rico, from Costa Rica, from Venezuela, from Guatemala, you name it.... To me it's such a positive thing that they can all come together and enjoy each other and help each other out. 305 While the Latino population of the county has continued to grow and diversify, narrators also spoke about forming community with people of other ethnic backgrounds. When asked if he had friends from other cultures and who did

\footnotetext{
302 Giores interview, October 3, 2013.

303 Villaseñor interview, November 11, 2013.

304 Corona interview, September 11, 2013.

305 Sanchez interview, August 2, 2013.
} 
not speak Spanish, Giores responded "Sí, se puede decir que sí. Amistades, sí.-Yes, you can say that. Friendships, yes." ${ }^{306}$ Laura Gamboa: "Tengo amigos Americanos, amigos Asiáticos, y los demás, pero la mayoria Latinos.-I have American [non-Latino white] friends, Asian friends, and the rest, but the majority Latinos." ${ }^{307}$

Eduardo Corona had a favorable view of the diversity of his neighborhood; he had ethnic Japanese and Indian (from India) neighbors in addition to white and Latino neighbors. Corona, who was happy that his son was forming friendships with youths of other ethnic and cultural backgrounds, offered his opinions on community building:

Sometimes we are isolated as a community from other communities.... We are just afraid or maybe we don't understand another community and because of the number of Latino people here we tend to stay in the group.... We purchase our groceries in Mexican stores and we go to the parties with other Mexicans and we tend to organize with other Latinos but not open to multicultural... I think we need to work a lot on this side to blend our Latino community with broader diversity and trying to break down this isolated sense of just Latinos that are here as a group. ${ }^{308}$

Arturo Villaseñor, who also had friends of diverse ethnic and cultural backgrounds, spoke about building a broader community. "We have a partnership with a retirement center, and some of my students go there to try to catch more English in an everyday conversation. But they develop really, really high ties with

\footnotetext{
306 Giores interview, October 3, 2013.

307 Laura Gamboa interview, October 17, 2013.

308 Corona interview, September 11, 2013.
} 
the people living there.... And that's powerful."309 Villaseñor also saw an opportunity to connect with non-Latino immigrants. "I still have high hopes that this place will be a better place, more open to immigrants. Not Latinos necessarily, right now I'm working with some other minorities in Aloha.... You go to one of these project meetings and you can see some people from Africa.... Somalis, most of them, and they're facing the very same challenges that Latinos [are]."310

Most of the Mexican immigrant narrators spoke of forming friendships and creating community across lines of linguistic and cultural differences. While a sense of an overarching, intra-ethnic community among Latinos had weakened since the 1960s and 1970s, narrators spoke favorably of recollections of, and prospects for, using a variety of commonalities to create friendships with neighbors, co-workers, and fellow immigrants. Narrators saw opportunities to build community with both other Latinos and non-Latinos.

\section{"I'm not going to waste my privilege": Mexican immigrant narrators and education}

Mexican-born narrators shared their perceptions of experiences with formal education in the 1990s and 2000s. The tejano narrators who settled in the 1960s, too, noted their perceptions of the changes that had taken place in the decades since their arrival. Narrators' accounts suggested that the experiences of students within county schools in recent years differed considerably from what ethnic Mexican students experienced in the 1960s. During the 1990s and 2000s, public schools in

309 Villaseñor interview, November 11, 2013. 310 Ibid. 
the county moved to better address the needs of increasing numbers of Latino, migrant, and other minority students. Students benefitted from considerably improved educational opportunities. Hector Hinojosa:

Our schools even in Beaverton are bilingual. Some of those schools are 50 percent Hispanics and they're having to offer bilingual education.... We now have bilingual teachers and counselors and principals and superintendents of school districts that are bilingual, bicultural or Mexican heritage or Latinos from Latin America. ${ }^{311}$ One of those individuals in a position to influence the educational experiences of students of different cultural and linguistic backgrounds was narrator Enedelia Hernandez Schofield. At the time of our interview in August 2013, Hernandez Schofield served as the principal of Butternut Creek Elementary in Aloha. During her years as a student:

I didn't have role models ... my mentors were white people but I didn't have people of color to look to, besides my mother and father and those people in leadership roles in the church... I know that I see evidence every day in my school and in my community from kids who will go, "oh my gosh, that's Enedelia, she speaks Spanish and she's a principal." And so again you have that unconscious impact. ${ }^{312}$ In addition to being a leadership figure with whom ethnic Mexican and other Latino students could identify, Hernandez Schofield helped shape learning environments that better addressed the needs of ESL students and students of different cultural backgrounds. Hernandez Schofield applied the lessons of her own struggles in Washington County schools to the challenges facing ESL and minority

311 Hinojosa interview, July 29, 2013.

312 Hernandez Schofield interview, August 28, 2013. 
students. She became the first Latina principal of an Oregon public school in 1993, when she started at Echo Shaw Elementary. At the Cornelius school, 80 percent of the students spoke Spanish as their first language and many students came from impoverished families. Hernandez Schofield created tutoring and second-language programs. Due in part to her efforts, by 1999 "93 percent of Echo Shaw students met the state's reading standards and 80 percent met math standards." ${ }^{313}$ Students were performing so well that some individuals thought that Echo Shaw administrators had fabricated test results-an allegation reminiscent of the accusations of cheating that Hernandez Schofield faced in middle school for doing so well on her math tests. In 2002, she was appointed to President George W. Bush's Commission on Educational Excellence for Hispanic Americans, a twenty-one-member group tasked with identifying ways to erase the gap between white and Latino students on standardized achievement tests. ${ }^{314}$

In 2003, the Hillsboro School District opened the Office for Hispanic Outreach with the aim of closing the achievement gap between white and Latino students. Olga Acuña, a former migrant student who arrived in Oregon in 1990, was named the coordinator of the center, and she sought to better involve migrant and Latino parents with their children's educational experiences. ${ }^{315}$ In the 1990s and 2000s,

313 Paige Parker, "The Monday Profile Latina Principal Hugs Her Way Into Students' Hearts," Oregonian, April 8, 2002, A01.

314 Ibid. After graduating from Pacific University, Hernandez Schofield earned a Doctorate of Jurisprudence from the Lewis and Clark School of Law in 1985 and a Master of Arts Degree through Portland State University's Portland Public School Administrative Program in 1991.

315 Shirley Dang, "Hillsboro Schools Reach Out to Latino Parents-The District Opens an Office for Hispanic Outreach, Aimed at Bolstering Efforts to Close an 
Hernandez Schofield and Acuña, along with other former migrants and Latinos, exercised increasing influence in county schools as administrators and educators. They implemented programs, such as Hernandez Schofield's second language and tutoring programs, to better serve a growing body of migrant and Latino students.

Other programs assisted and encouraged migrant education at primary, secondary, and post-secondary levels. In 1998, attendance in the Washington County Migrant Summer School, a free program in existence since the 1960s, was higher than ever. The bilingual program provided instruction to help migrants catch up on work and lessons missed due to frequently changing schools. ${ }^{316}$ In 2006 , Portland Community College's (PCC) Rock Creek campus was awarded a five-year, \$1.5 million U.S. Department of Education Grant to provide "financial aid, tutoring, and mentoring services to seasonal and migrant farmworkers and their children" to help them earn college degrees. ${ }^{317}$ The college was one of eight in the nation to receive the grant. In 2011, with funding from a five-year, \$2.24 million grant, PCC Rock Creek began to offer a High School Equivalency Program to provide seasonal migrants a path to obtaining a GED through night courses. Students who completed the program were allowed to take up to twelve credits within the next year at PCC free of charge. ${ }^{318}$ In 2012, Andrea Castillo reported on the workshops hosted by the

Achievement Gap," Oregonian, October 23, 2003, 07. “Stable Roots Help Students Flourish: Knowing that Repeated Moves Create Hardships for Kids, Migrant Families Find Places to Settle," Oregonian, October 30, 2013, A01.

316 Art Marroquin, "Migrant Youths Crowd Bilingual Summer School," Oregonian, July 22, 1998, B02.

317 Melissa Navas, “College Struggles to Give Away \$1.5 Million in Aid,” Oregonian, June 18, 2007, B01.

318 Kelly House, “Improving Lives Through Education,” Oregonian, March 26, 2011. 
Forest Grove School District to invite the parents of migrant and ESL children to be more actively engaged in their children's educational experiences. ${ }^{319}$

New programs built upon existing opportunities for migrants and their children to pursue formal education. Andrea Castillo reported on migrant education in 2013. "Before the Migrant Education Program started in 1966, more than 90 percent of migrant students dropped out of school nationwide. Last year in Oregon 55 percent graduated in four years, compared with 69 percent of non-migrant students." 320 The Migrant Education Program and other programs developed at individual schools and school districts had a hand in this significant rise in graduation rates.

Two of Eduardo Corona's children, aged twelve and fourteen, attended public schools at the time of his interview in 2013. While he and his family were not impoverished seasonal migrants, his children benefitted from the culturally and linguistically sensitive programs at the schools they attended. He shared his impression of the school system in Beaverton:

It's very good-very good opportunities.... My son was a little depressed when we came here in 2010 and we have a lot of support in the elementary school.... He's a TAG (Talented and Gifted) student so he's now taking advanced classes in math and sciences.... We have a counselor in the school. I feel it was very good compared to Guadalajara, Mexico [where the family resided for several years

\footnotetext{
319 Andrea Castillo, "Parent Group Helps Bridge Culture Gap, Support Education," Oregonian, December 19, 2012, FG.

${ }^{320}$ Andrea Castillo, "Stable Roots Help Students Flourish Knowing that Repeated Moves Create Hardships for Kids, Migrant Families in Oregon Find Places to Settle," Oregonian, October 30, 2013, A01.
} 
before the most recent move to Oregon].... My daughter was so afraid the first time she came to the school that she was crying. She didn't want to go to the junior high. We talked to the counselor, and we have a tutor in the school and she's doing very, very well.... She's advanced also. 321

Eduardo Corona appreciated that his son was able to make friends with white and African American students by playing on a soccer team. "He is more exposed to having more friends in different ethnicities, which is something I love." 322 Ariadna Covarrubias Ornelas began fifth grade after moving to Cornelius: I started with no English and I was in the ESL class at that time.... Most of the people there spoke only Spanish. By the end of that time, my fifth grade, I was about first, second grade reading level. By the end of my first semester in sixth grade I was around third grade reading level. ... seventh grade the first semester was the last time I was ever in ESL class. And then in the second semester of seventh grade I started with regular English and then honors after that. 323

Covarrubias Ornelas formed a social circle mostly with other students that she met in ESL classes. As a new English speaker and a newcomer to the United States, Covarrubias Ornelas struggled to connect even with other students who spoke Spanish as a first language: "It was kind of difficult to make friends with them because they had been immersed in the culture in this country for about more than a year or their whole lives.... A lot of them disconnected from their country of

\footnotetext{
321 Corona interview, September 11, 2013. His oldest daughter was studying at a university in Mexico at the time of the interview.

322 Ibid.

323 Covarrubias Ornelas interview, June 12, 2013.
} 
origin." 324 Whether it was because she was the new kid at school, or because of the cultural differences with peers who had spent more time in the United States, Covarrubias Ornelas felt that other students treated her poorly at times. "Being from Mexico ... I was a bit discriminated [against] just because of the fact that I didn't know. I wasn't used to the culture here and their sense of humor. I got hurt really easily." 325

Transitioning to life in Oregon was not easy for Covarrubias Ornelas, and she struggled with English. "Even now I'm still a little bit iffy because I can hear when I don't pronounce words correctly, when I can't, for the love of anything, just look at a word and try to pronounce it." ${ }^{326}$ Her struggles with the English language and her struggles to adjust socially and culturally to life in Washington County did not dampen her ambition, however. Covarrubias Ornelas, who excelled at math since her elementary school years in Michoacán, continued to do well in school in Cornelius with the support of her family. Although neither of her parents had completed any formal education past the primary school level, they supported her educational pursuits:

I have the privilege to keep going to school. And they didn't. So I'm not going to waste my privilege.... When I was in high school they never asked me to get a job. They didn't ask me to stop my homework and help them out or with the cleaning.... I want to show them that what

\footnotetext{
324 Ibid.

325 Ibid.

326 Ibid.
} 
they sacrificed isn't something I'm just wasting. It's something I'm using. And I want to help them out, too. 327

During high school, Covarrubias Ornelas found herself intrigued by biochemistry and decided to make it the focus of her higher education aspirations: “That was one of the things that motivated me... it wasn't easy. You are required to know math, chemistry, biology.... It would never be boring. It was always going to be challenging because there's just not one thing in front of you that says 'this is what happens."'328 In 2010 Covarrubias Ornelas graduated as a valedictorian from Forest Grove High School, gave a speech in front of her graduating class, and served as the keynote speaker for the Spanish-language commencement ceremony at Centro Cultural honoring graduating seniors from immigrant and other Latino families. At the time of her interview in June 2013, Covarrubias Ornelas had completed her Associate of Arts Oregon Transfer Degree and was set to begin an internship with Oregon Health \& Science University. She planned to transfer to Portland State University and then obtain an advanced degree. "I want to go into research. I want my PhD in biochemistry. I just want to keep going as far as I can."329 Her parents took satisfaction in knowing that they had created opportunities for their daughter by encouraging her to pursue an education:

They're happy that I found something that I'm happy with and that [I'm] just pursuing because I want to, not because I have to, and it's

\footnotetext{
327 Ibid.

328 Ibid.

329 Ibid. "79 Commence from Centro Cultural," Jessica Bania, Portland Tribune, 3 June 2010, http://cni.pmgnews.com/component/content/article?id=30959, accessed January 14, 2014.
} 
not going to be something as labor intensive as what they're doing.

Because my mom said, "I don't want her going out into the fields."330

The stories that Covarrubias Ornelas and Corona shared highlighted how educational opportunities had changed since the 1960s and 1970s. Schools had shifted from ignoring or discriminating against Latino, ESL, and migrant students to designing specific programs to help them succeed in the Oregon school system. These programs did not erase the achievement gap, but did help motivated and intelligent students with supportive families, like Ariadna Covarrubias Ornelas and the children of Eduardo Corona, adapt to the school systems and curriculum. ${ }^{331}$

“Uno no se puede quejar-One can't complain”: Mexican immigrant narrators and discrimination

In their interviews Mexican-born narrators recalled interactions with, and discrimination from, white residents. Eduardo Corona remembered receiving poor service and rude treatment from the wait staff and the manager of a Hillsboro restaurant, which he believed to be due to his accent and his appearance. He also remembered hearing stories of discrimination against other ethnic Mexicans and Latinos, but felt “otherwise I think I've been very comfortable here... . I didn't face a bad situation beyond the one that I told you."332

Corona remembered that, while living in Riverside, California, "I felt a little segregation to the Latino community," and that he had been mistreated there

330 Covarrubias Ornelas interview, June 12, 2013.

${ }^{331}$ Giores, Villaseñor, and Laura Gamboa all had children in county schools at the time of the interview as well, but the educational experiences of their children were not discussed in comparable detail during their interviews.

332 Corona interview, September 11, 2013. 
multiple times due to his ethnicity. Washington County compared favorably to California in that regard. "I love here because here is much more open-minded to all cultures. ... Much better for all kind[s] of people than in California."333

Corona offered a story to highlight his experience in Washington County. While canvassing for a group collecting public opinions on rights for undocumented immigrants, he had an exchange with a "sixty-something, mainstream white lady" who was firmly opposed to extending rights to the undocumented and felt that they should leave the country. Corona began asking her questions about her beliefs. "I wasn't looking for a confrontation but I want to know why she was thinking that way. And as I was talking she was changing and changing. And the last thing she said is that, 'I'm Republican. I'm registered Republican... . But I don't support racist laws so I have to think, myself, about it."'334 Corona believed that her willingness to dialogue with him was indicative of the social environment in the county: "That's why I feel very comfortable. People are open to hear, to speak up."335

Laura Gamboa recalled two instances of what she perceived to be ethnic discrimination: she was stopped by a police officer on dubious grounds of having a light out on her car and hassled about her driver's license, and once at the bank an employee refused to accept her license as proof of her identity and pressured her for another form of identification..$^{336}$

\footnotetext{
333 Ibid.

334 Ibid.

335 Ibid.

336 Laura Gamboa interview, October 17, 2013.
} 
Arturo Villaseñor recalled that members of Oregonians for Immigration Reform, a group vocally opposed to extending rights to undocumented immigrants, would show up outside of Centro Cultural every other week to protest the center and harass people entering the building. He described these and other instances of overt hostility as "isolated episodes, most of the time." 337 Although Villaseñor spoke more about discrimination between Latinos in Washington County, he did not overlook instances of racism from non-Latino residents:

The only thing that maybe I do not like is that there are still here in Oregon, some people at some places that are very conservative, that are not progressive. Some people here that are racist or are against new immigrants, wherever they come from. I don't like that. I think Oregon is a wonderful place to live, but maybe they don't understand. Maybe they don't know that the immigration is a good deal for every place, actually. ${ }^{338}$

When asked if he had been the victim of racism or discrimination in Oregon, Giores replied "No, de ninguna forma-No, not in any form." 339 Asked a subsequent question about how clients and superiors treated him at work, Giores's response suggested that he might not have felt he had the right to complain about treatment from employers and clients:

Bien, o sea, uno no se puede quejar porque uno sabe perfectamente pero al menos yo sé perfectamente que uno está en otro país. Y no sé, la gente también tiene sus derechos a pensar o reaccionar de tal o cual forma, a vernos.

337 Villaseñor interview, November 11, 2013.

338 Ibid.

339 Giores interview, October 3, 2013. 
Well, or it's that, one can't complain because one knows perfectly, at least I know perfectly well that one is in another country. And I don't know, the people also have their rights to think or react in whatever way, to see us. ${ }^{340}$

Perhaps, due to his Mexican nationality, Giores also did not feel that he had the right to complain about being treated in a different or discriminatory manner in Oregon.

It is possible that narrators downplayed experiences of racism and discrimination to avoid focusing on relatively recent negative experiences for their own well-being, to avoid going on record about problems within their communities, or because they felt reluctant to share their feelings on the subject with an interviewer from a white, English-speaking background. Ann V. Millard and Jorge Chapa, in Apple Pie \& Enchiladas: Latino Newcomers in the Rural Midwest (2004), spoke with both white and Latino residents of the Midwest regarding discrimination. The authors recognized how the status of the interviewers might have affected the responses of the Latino interviewees: "Regarding our methods of gathering data from Latinos, although our research team includes Latinos and Anglos, we all look Anglo enough that some Latinos may not have felt free to criticize Anglos as a group." 341

In similar fashion, my status as a non-Latino white may have discouraged some narrators from fully expressing their opinions about and recollections of racism. During our recorded interview, one narrator did not bring up a memory of

340 Ibid.

341 Ann V. Millard, Jorge, Chapa, and Eileen Diaz McConnell, "'Not Racist like Our Parents': Anti-Latino Prejudice and Institutional Discrimination," in Apple Pie \& Enchiladas, 107. 
discrimination from a police officer that the narrator had shared with me freely during a pre-interview session. Some narrators many have felt especially discouraged from going on record discussing instances of discrimination from law enforcement or other individuals in positions of power.

Arturo Villaseñor's statements about racism and inequality in Mexico offered another possible explanation why Mexican immigrant narrators either claimed not to recall instances of discrimination in Washington County or described the discrimination they experienced as confined to isolated incidents and reflective only of the prejudices of a few:

In Mexico we have a lot of racism ... it's terrible sometimes. I was talking with a friend and sometimes you can see more racism than in the United States. Really, like just last week a family from Oaxaca, they didn't allow them to go to the plane to take a flight because they looked [indigenous, wearing traditional clothes]. In Mexico people are not really confident with the system. They don't trust the authorities and we move here, well you can see that you can trust the authorities most of the time. ${ }^{342}$

Narrators relocating from Mexico witnessed severe inequality, abuses of power, and discrimination along class and ethnic lines before relocating to the United States. This may have conditioned some of them to accept discriminatory treatment in Washington County as normal.

At least one individual worked hard to improve relations between law enforcement and Latino migrants and residents in the county. Lorenzo Rubio, who hosted a radio show as mentioned in chapter II, spent twenty years with the 342 Villaseñor interview, November 11, 2013. 
Washington County Sheriff's Office. Rubio began as a volunteer interpreter for the office and performed a number of duties before retiring as a crime prevention officer in 2013. For years, he was the only Spanish-speaker working for the office. He served as an interpreter for investigations, translated written materials, and helped ease tensions between Latinos and law enforcement. "That work was important," Rubio said in a 2013 article for the Oregonian, "because not all law enforcement agencies have liaisons to bridge the gap between English-speaking police and Spanish speakers." 343 Rubio used his background as a former migrant worker to establish rapport with many of the county's Latino farmworkers. His own memories of hardships due to prejudice and discrimination-he recalled a landlord who evicted him for being Mexican-helped motivate his work to assist arriving Latinos. "I also tried specifically to get the two cultures-law enforcement and Latino-to understand each other," he said. "There are a lot of misconceptions or misperceptions from both sides." 344

While a number of factors may have discouraged Mexican immigrant narrators from identifying or speaking about discrimination against them, a comparison of their responses on this issue to the responses of the tejano narrators suggests that episodes of overt discrimination had decreased since the 1960s. Most

\footnotetext{
343 Andrea Castillo, "Retiring Officer Leaves Legacy of Helping Others," Oregonian, January 5, 2013.

344 Ibid. Lorenzo Rubio also helped migrants and immigrants through his longrunning radio show that he co-hosted with his brother, Andy Rubio. New arrivals and others would call the brothers for help at the number for the show, and the Rubio brothers would connect these people with the appropriate resources. Cristine Gonzalez, "The Brothers Rubio Use Radio Show to Meet the Needs of Latinos," Oregonian, June 4, 1998, 01.
} 
of the Mexican immigrant narrators who did recall incidents of discrimination in Washington County spoke of only a handful of episodes. The tejano settlers, by contrast, offered many more specific examples or spoke about overt discrimination as an ongoing, regular experience. Narrator responses to these questions suggested that while discrimination and ethnic prejudice continued to present problems for ethnic Mexicans, these problems did not affect their daily lives in overt and often confrontational incidents in the 1990s and 2000s to the degree that they did for the tejano narrators in the 1960s and 1970s.

\section{"I have my house, but my home is my family": Mexican immigrant narrator impressions of life in Oregon}

While most commented favorably on life in Washington County and the state of Oregon, even while acknowledging discrimination as an ongoing problem, narrators spoke in different ways about their relationships to their current places of residence. Giores made an effort to highlight his positive impressions of Englishspeaking society in Oregon:

La cultura norteamericana es grandiosa porque nos enseña muchas cosas a respetar al ser humano, y nos da confianza en otras más. Y de mi actividades, he tenido la experiencia de que el norteamericano te acepta, abre su espacio, su tiempo para escucharte, para oírte.

North American [U.S.] culture is great because it teaches us a lot about respecting human beings, and it gives us confidence in others. From my activities, I have had the experience that the North American accepts you, opens his/her space to you, his/her time to listen to you, to hear you. 
Me ha tocado mucha gente muy amable desde los maestros de inglés que te enseñan el inglés. Te muestran que con su voluntariado.... Se preocupan por la gente, no solamente por su propia gente de su comunidad sino hacia nosotros como nosotros los hispanos. .. Algunos se preocupen mucho por hablar Español. Por llegar también a comprender a nuestra comunidad.... Y te digan, "oye, que bien que estás haciendo un buen trabajo," que te reconozcan.

It's touched me-many very friendly people, from the English teachers. They show you with their volunteer work... They are concerned with the people, not just their own people of their community but towards us the hispanos.... Some are very concerned with learning Spanish, to try to understand our community as well.... [Regarding work] They tell you, "hey, that's great that you are doing a good job." They recognize you. ${ }^{345}$

Arturo Villaseñor found other things to like about life in Oregon. A self-described "trekkie" (Star Trek fan) who grew up watching U.S. movies and television programs, Villaseñor always had some interest in Englishspeaking culture and appreciated the process of learning English. "I like the sound. I love the language. That's why I am trying still to learn English."346 Although he acknowledged the problems of prejudice and discrimination, Villaseñor was favorably impressed by life in Oregon:

I love it. I remember the very second time that I travel here in this area, and I just love the situation that you take the MAX [Metropolitan Area Express light rail] or the TriMet [City and Tri-Country Metropolitan Transportation] bus and people just started talking without previous[ly knowing] each other... In Mexico didn't happen

345 Giores interview, October 3, 2013.

346 Villaseñor interview, November 11, 2013. 
that way, and I just love this openness with people here in the states. At least people here.... Portland reminds me a little of Mexico City. It's a smaller city but there's always people in the streets and I love that. 347

When asked about her opinion of English-speaking U.S. culture, Laura Gamboa offered the following response:

Digamos que las nuevas generaciones como que entienden más al latino. Pero pienso que la gente más mayor necesita ser educada porque a veces piensan que nosotros venimos a quitar al trabajo, pero en realidad no venimos a quitarle el trabajo a nadie.

Let's say that the younger generations, that they understand Latinos more. But I think that the older people need to be more educated [about us] because sometimes they think that we come to take away work, but in reality we don't come to take away jobs from anybody. ${ }^{348}$

On a positive note, Gamboa recalled non-Latinos actively socializing more with Latinos in recent years. ${ }^{349}$

Es un estado que es seguro. Ya no tan seguro, pero es más seguro que, por ejemplo, California o Chicago. Me gusta también porque tiene muy hermosos paisajes y también su gente,-It's a safe state. Not so safe, but more safe than, for example, California or Chicago. I also like it [Oregon] because it has very beautiful landscapes and also its people, 350

Gamboa said in offering her opinion on Oregon, even as she restated that some residents held negative preconceived notions about Latinos. ${ }^{351}$

\footnotetext{
347 Ibid.

348 Laura Gamboa interview, October 17, 2013.

349 Ibid.

350 Ibid.

351 Ibid.
} 
For Ariadna Covarrubias Ornelas, the importance of family superseded the importance of place. When asked if Oregon felt like home to her, she responded:

I really don't know what people mean when they say a location is a home because my home is with my family. I always carry them with me. Doesn't matter if I'm not with them, they're still my home. Oregon is a nice place to live. I have my house, but my home is my family. ${ }_{3} 32$ Eduardo Corona expressed appreciation for the opportunities for civic participation that he had experienced in Washington County:

Being Americans working for the community and having all these values about the community, the country, the things you have to do because it's their right, and feeling yourself that you have to speak up about yourself and your community. That's the other thing that I love.... I came here very late [in life] and I speak with a big accent but I identify with American values and speaking up and rights and citizenship. So in that sense I feel American. ${ }^{353}$

While some narrators offered important critiques of Oregon society, they emphasized social and financial opportunities over their frustrations, hardships, and experiences of discrimination. Eduardo Corona and Laura Gamboa offered perceptions that conditions in Washington County compared favorably to elsewhere in the nation.

\section{"New expansion and new people": The continuing importance of Centro Cultural and Virginia Garcia Memorial Health Center}

In creating Centro Cultural, Virginia Garcia Memorial Health Center, and other social service organizations during and after the early 1970s, the tejano 
settlers and their allies helped to create a support system both for migrants residing seasonally and for those living permanently in the county. There were other important resources that directly or indirectly assisted immigrants, such as the Mexican consulate in nearby Portland that helped protect the legal and human rights of Mexican citizens in the region, migrant education programs created by the state and by local school districts, and the state's regulation of farmworker camp conditions through the Oregon Occupational Safety and Health Division. In addition, the county hosted a number of organizations that had been founded through the initiatives of residents to provide specific types of assistance to the Latino population. In 1999, Clackamas County Circuit Judge Deanne Darling commented on Washington County's wealth of resources for its Spanish-speaking population in comparison to her own county. "It was amazing.... They just had unlimited resources." ${ }^{354}$ Some Clackamas County caseworkers turned to Washington County to find bilingual foster parents or other resources for their Latino residents. 355

The existence of Centro Cultural and Virginia Garcia Memorial Health Center encouraged subsequent the formation of other organizations, such as Adelante Mujeres, that addressed specific gaps in serving the Latino population. That most of the Mexican-born narrators benefitted directly from this support system, or saw the importance of it, testifies to the long-lasting impact of community-based efforts to help other ethnic Mexicans and Latinos with a broad array of services. Most

354 Jill Smith, "Latinos Feel Shortage of Services in County," Oregonian, November 4, 1999, 01.

355 Ibid. 
narrators mentioned Centro Cultural as an organization that played a role in their lives. Laura Gamboa:

Yo lo conocí por mi mamá porque ese fue un lugar donde ella recibía diferentes recursos como era comida, ropa, y donde poder ir a trabajar. Yo, como supe de ese lugar es por mi trabajo también. Porque allí nos daban a veces este-algunos entrenamientos. I learned about it [Centro Cultural] through my mother because that was where she received different resources like food, clothes, and where to go for work. I also knew about the place through my work. There, they sometimes gave us some training. ${ }^{356}$ Giores recalled going to two places for assistance after arriving in the county, St. Alexander Parish—the church he attended after settling-and Centro Cultural. ${ }^{357}$ Ariadna Covarrubias Ornelas's family celebrated Children's Day with the event hosted by Centro Cultural. ${ }^{358}$ As mentioned earlier, Centro Cultural hosted a commencement ceremony for high school seniors at which Covarrubias Ornelas was honored as the keynote speaker. ${ }^{359}$ Through hosting celebrations, providing vocational training, and offering basic material assistance, Centro Cultural supported these Mexican immigrant narrators.

Arturo Villaseñor volunteered and then worked at Centro Cultural teaching computer, math, and Spanish classes before moving on to other opportunities. ${ }^{360}$ In describing community opportunities for Latinos, Villaseñor cited two organizations that had been established largely through the efforts of the early tejano families.

\footnotetext{
356 Laura Gamboa interview, October 17, 2013.

357 Giores interview, October 3, 2013.

358 Covarrubias Ornelas interview, June 12, 2013.

359 Ibid.

360 Villaseñor interview, November 11, 2013.
} 
"Cornelius is a thriving community. You can see the change in just ten years. We have Centro Cultural growing, new expansion on Virginia Garcia, new expansion and more people to serve Latinos there."361

Virginia Garcia Memorial Health Center, the center started in a garage in the 1970s, expanded the scope of its services as it continued serving migrant and seasonal workers and others who had difficulty accessing adequate healthcare services. According to the organization's website in 2014, the center had grown to serve over 35,000 patients annually with "four primary care clinics and pharmacies, three dental offices, and three school-based health centers," as well as a mobile clinic that provided services at schools, migrant farmworker camps, and large-scale plant nurseries. ${ }^{362}$ While much of the social cohesion that defined the original Spanish-speaking community of the 1960s was lost over subsequent decades, Centro Cultural and the Virginia Garcia Memorial Health Center-two institutions created through the efforts and sacrifices of the tejano settler families and their supporters-expanded to deliver a widening array of services to an ever-growing Spanish-speaking population. The vital, far-reaching services they provided honored the mutual assistance values of the early tejano settlers and served as reminders of their community building efforts.

361 Villaseñor interview, November 11, 2013.

362 "About Virginia Garcia Memorial Health Center," accessed online January 28, 2014. 
"It's like a name": Spanish language, cultural identity, and cultural replenishment

While the answers and opinions that tejano and Mexican immigrant narrators shared on interview topics and questions varied widely, most of them highlighted the importance of an identity tied to the Spanish language and connected to Mexican ethnicity and culture. ${ }^{363}$ For the narrators, Spanish was essential in order to fully express themselves. They saw honoring their Mexican or Mexican American identities as crucial to their sense of self.

Hector Hinojosa described an identity that was tied both to Spanish language and Mexican American culture and to the English language and English-speaking U.S. society:

I would be awfully lonely if I only had to function in English for example.... You'd quickly begin to miss your food, music, movies, socializing, fellowshipping.... Being bilingual, bicultural is very important because I think I would have a tough time functioning today in Mexico all in Spanish only, with only Mexican food, with only Mexican TV and radio, music, etc. I would begin to miss my roots back home in Oregon, the English side. ${ }^{364}$

As with Hinojosa, life in Oregon had influenced the other ethnic Mexican narrators to construct bilingual and bicultural identities. Though they fashioned their identities in different ways, each narrator emphasized the importance of continuing to perform mental, written, and verbal tasks in the Spanish language.

363 The two narrators who participated in Spanish-language interviews were not asked questions about the importance of Spanish in their lives. 364 Hinojosa interview, July 29, 2013. 
Arturo Villaseñor: “Well it's [the Spanish language is] very important. . . . I love my language-Spanish. I love it. I also teach in Spanish.... So it's quite a part of my identity."365

Evangelina Sanchez:

My son just told me the other day, he said, "you know what I noticed about you mom? That when you want to give us advice and you really want it to hit our hearts you say it in Spanish ... " I said "I just feel like it has a different meaning when I say it in Spanish."366

Ariadna Covarrubias Ornelas:

When I started writing poetry in Spanish I discovered I could do a lot more because I could describe things a lot easier. I could get more specific or more broad with Spanish. I didn't have to-there was not as many restrictions as with English.... I still have the foundation of kindergarten to fourth grade of the variety of words.... At the beginning of April I went to a workshop where we were given the opportunity to speak in our own language. And when I spoke in Spanish about the topic I had felt that I could describe myself better. That I could communicate better what I was feeling. ${ }^{367}$

Enedelia Hernandez Schofield:

It's like a name. It's you and there are things that you experience through the language that-it's just unique. So, language is huge. I think language really creates another foundation as to who you are.... There are words you can't translate. There are feelings and situations that you just can't translate. ${ }^{368}$

\footnotetext{
365 Villaseñor interview, November 11, 2013.

366 Sanchez interview, August 2, 2013.

367 Covarrubias Ornelas interview, June 12, 2013.

368 Hernandez Schofield interview, August 28, 2013.
} 
The significance of Spanish language and Mexican/Mexican American culture to the narrators underscored the importance of resisting total assimilation. The loss of linguistic skills and cultural practices would constitute a loss of identity for these narrators. To this end, the continuing influx of Mexican and other Latin American immigrants, both on a national and a local level, helped ethnic Mexican residents in Washington County preserve their language and culture.

Hector Hinojosa spoke of cultural replenishment in relation to other ethnic groups. He compared the process of cultural renewal among Asian and Pacific Islander Americans to that experienced by Latinos in the United States. "They have a replenishing of refugees coming in," he said, and felt that the active cultural practices of new arrivals helped others of their same ethnic backgrounds better connect to their personal or ancestral cultures and communities of origin. "They're [new arrivals] practicing their religion, their education, their culture, their music. All of that is being - they're keeping that alive."369

For Hinojosa, cultural replenishment was vital. At several times during the interview he spoke of the importance of language and culture to one's sense of identity. Cultural replenishment, according to Hinojosa, constituted one important defense against an assimilation that denies cultural and linguistic diversity. Since before the formation of the Washington County tejano community in the 1960 s, elements of the white majority population in Oregon had vocalized the belief that such assimilation was both imperative and inevitable. In 1952, Lutheran Welfare Association Director Eugene Schuttner implied that migrant workers-at this time 369 Hinojosa interview, July 29, 2013. 
the state's migrant workforce was increasingly comprised of tejanos and other Mexican Americans_could become upstanding members of Oregon society with time as they ceased to migrate and therefore lost ties to their regions and communities of origin: "Their roots will set. Their yearning for their homelands will give way and they will become good citizens."370

The idea that migrants and former migrants-turned-settlers could become "good" citizens through the loss of ties to home communities and their full embrace of the majority culture in their new communities pervaded the discourse of the dominant white culture in the mid-twentieth century. In the 1960s and 1970s, it inspired administrators to forbid students like Hector Hinojosa to speak Spanish at school, and it encouraged teachers to assign English language names to pupils, like "Annie" for Enedelia Hernandez Schofield.

Some ethnic Mexicans in Oregon suffered a loss of cultural and linguistic identity due to assimilation pressures and the relatively small size of the ethnic Mexican/Latino population in the state. Mike Flores of Portland, whose family had moved from Texas in 1944 and who had rebuilt their lives after losing their home and all of their belongings in the Vanport Flood, lamented the loss of his Spanish language comprehension in a 1976 newspaper interview: "It embarrasses me that I don't speak Spanish. I lost it completely." 371 The author of this article, profiling middle-class Mexican Americans in Oregon, linked prosperity with assimilation, and

370 “Official's Story of Migrants Draws Challenge by Solon," Oregonian, October 1, 1952, 12.

371 "Mexican-American Men Say Their People Give Full Value," Oregonian, June 13, 1976. 
assimilation with the loss of ethnic Mexican heritage. "Only a small piece of a Mexican past remains with Flores, who has almost totally assimilated into a typically American middle-class lifestyle." "Mike Flores, owner of a successful woodworking business, says he's almost totally assimilated as a middle-class American, but clings to his Mexican past [emphasis mine]."372 The article reflected the belief that individuals of marginalized and minority ethnic backgrounds had to abandon or downplay their cultural heritage in order to succeed financially and socially in U.S. society. The article described Mexican ethnicity, Mexican culture, and the Spanish language as barriers to success.

Hinojosa recalled a more recent, less overt example of the assimilation mindset at work when a new priest from Mexico was introduced at a meeting attended by deacons and board members for Hinojosa's Catholic parish:

One of the ladies said, "do you mind if I call you Father Joe?" And he says, "no, that's not my name. My name is Father José U." ... This lady wants to change his name, who he is.... That's the ugly side of forced assimilation.... You begin to deny other people their identity for your sake. 373

For Hinojosa, the continuing influx of seasonally migrating and permanently settling people from Mexico and elsewhere in Latin America offered him, other residents, and subsequent generations of ethnic Mexicans and Latinos the opportunity to remain in touch with their ancestral culture and language, and also offered a defense against forced assimilation. "It's going to be more difficult to

\footnotetext{
372 Ibid.

373 Hinojosa interview, July 29, 2013.
} 
assimilate over years because it's constantly being renewed by having Mexico as a border... They're coming in and replenishing our values." ${ }^{374}$ Though the Mexican/Latino cultures that immigrants brought with them varied by region and nation and continued to change over time, Hinojosa could relate to the language and to broad cultural elements that he shared with Spanish-speaking arrivals. Their presence and freshly transplanted cultural practices encouraged him to further honor his own identity and the culture specific to his family and their region of origin. As Hinojosa described it:

The second and third generations are starting to forget their roots and heritage.... [but] I find for the most part that they go back and and get their heritage. I see that within my own kids. I think they're realizing, "maybe I should have paid a little more attention"... [They] make the extra effort of embracing both. ${ }^{375}$

According to Hinojosa, Cinco de Mayo had taken on a special significance for him and other ethnic Mexicans to both honor their culture and share it with others:

Look at what we do at the [Portland] waterfront-Cinco de Mayo celebration. Cinco de Mayo is no Mexican Independence Day like they think it is here.... Cinco de Mayo has become such a popular celebration now that both in the European American and the otherAsian-Pacific Islanders, Native Americans, and African Americans embrace that celebration.... It's also done some good across the border I'll say with the Native Americans ... embracing, accepting, and celebrating now with us. ${ }^{376}$

374 Ibid.

375 Ibid.

376 Ibid. 
"My kids see more culture around them that I didn't get to"

"In some ways, things are easier for today's immigrants than they were 20 or 30 years ago," wrote Jerry F. Boone for the Oregonian in 2006. "Cities such as Independence, Woodburn, and Hillsboro have grown into racially diverse communities where Latinos can live without giving up their cultural heritage." $377 \mathrm{~A}$ growing ethnic Mexican/Latino population allowed for the establishment of grocery stores, bakeries, and other specialty businesses serving the county's ethnic Mexican/Latino population in the 1990s and 2000s. ${ }^{378}$ Similar demographic trends on a national level encouraged retailers, entertainment providers, and other types of businesses to market their goods and services to Latinos and develop specialized products for them in an attempt to reach new consumer markets. ${ }^{379}$ Such products and specialty stores helped Latinos in the county maintain ties to their language, their culture, and their communities of origin. Enedelia Hernandez Schofield:

My kids see more culture around them that I didn't get to so they walk into any store and as they're going through the aisle, they can go to the Mexican aisle, the Asian aisle and they can pick up different spices and see. They can get on the internet and listen to music and they can listen to different genres. ${ }^{380}$

Communication and entertainment technology has helped ethnic Mexican residents in Washington County maintain cultural and linguistic ties. Both local and

377 Jerry F. Boone, "Immigrants Same as Others Who Had Dream," Oregonian, December 9, 2006, B01.

${ }^{378}$ Cristine Gonzalez, "Hispanics in Washington County Find More (Businesses Offering Familiar Goods)," Oregonian, March 9, 1995, C02.

${ }^{379}$ Steve Suo, “Companies Target Surging Latino Market," Oregonian, May 20, 2001, C01.

${ }^{380}$ Hernandez Schofield interview, August 28, 2013. 
national patterns of immigration and settlement from Mexico have significantly increased Spanish-language offerings on radio and television. Hector Hinojosa remembered:

In the '60s there was only one radio station, Sundays from six in the morning if you were lucky to be awake until eight o'clock. ... Today I can get up and turn on the TV and have twenty-four-hour Spanish, three or four radio stations, four or five radio stations in Spanish. That's replenishing. ${ }^{381}$

Communication technology and social media have helped Mexican immigrant narrators stay in touch with loved ones, follow developments within Mexico, and participate in discussions regarding events there. Eduardo Corona:

I don't need to travel to Mexico to participate in the social justice movement. ... Yesterday I have 1,600 tweets about my opinion on the movement against the constitutional reforms that they're trying to do in Mexico. 382

Corona's children used social media to stay in touch with the friends they made while attending school in Guadalajara. ${ }^{383}$ Through phone calls, Facebook, and video chatting, Laura Gamboa, Giores, and Arturo Villaseñor kept in contact with loved ones in Mexico. Villaseñor used the internet to pay close attention to news about Mexico. 384

Dangerous conditions in Mexico, high travel costs, and the time-consuming nature of travel made returning home difficult or impossible for these narrators-

\footnotetext{
381 Hinojosa interview, July 29, 2013.

382 Corona interview, September 11, 2013.

383 Ibid.

${ }^{384}$ Laura Gamboa interview, October 17, 2013. Giores interview, October 3, 2013. Villaseñor interview, November 11, 2013.
} 
Giores and Ariadna Covarrubias Ornelas had not been back to visit family members since relocating to the United States. Social media and other methods of communication technology allowed them to stay in touch with friends and family and stay updated with events in Mexico.

Even as the influences of English-speaking culture and the prejudices of some white residents continued to pressure Latinos in Washington County to fundamentally re-order their cultural and linguistic identities in recent years, some white residents were changing their perspectives on the value of the Spanish language and Latino cultures. Reporter Andrea Castillo spoke with Centro Cultural Director Jose Rivera in 2013:

[Rivera] said that as migrant families settle permanently into Oregon communities, the children pass their culture onto their peers. More than ever, Rivera said, Anglo families turn to Centro Cultural to learn Spanish, help their neighbors learn English and sign their children up for the organization's after-school and summer school programs. "It's more of like an immersion," he said, "now going both ways. The draw is through the kids." 385

Rivera noted increasing interest in the Spanish language and Latino cultures from white residents - a form of respect that Emilio and Hortencia Hernandez had worked to establish through the work that they began with Centro Cultural decades prior.

385 Andrea Castillo, "Stable Roots Help Students Flourish: Knowing that Repeated Moves Create Hardships for Kids, Migrant Families in Oregon Find Places to Settle," Oregonian, October 30, 2013, A01. 
Through their use of Spanish and transplanting of cultural practices of their home communities, Latin American immigrants to Washington County and elsewhere in the United States contributed to the process of cultural replenishment for all ethnic Mexican and Latino residents. By growing the size of the Latino population and its corresponding importance as a consumer market, Mexican and other Latin American immigrants (and subsequent generations born in the United States) also increased the options for specialized goods, services, and Spanishlanguage media for all ethnic Mexicans and other Latinos in the United States. Changes in technology have allowed these immigrants to remain connected with their home communities in Latin America and experience cultural replenishment through regular communication.

\section{A changed community, with lasting influence from early community builders}

Economic stagnation, financial instability, and changing political conditions within Mexico encouraged the Mexican-born narrators and many other Mexican nationals to relocate permanently to the United States during the 1990s and 2000s. The reasons that narrators relocated specifically to Washington County were tied to transnational community networks and migration patterns that first emerged in the 1970s with the arrival of significant numbers of Mexican nationals to the county. The Mexican immigrant narrators, like the tejano narrators who arrived in the 1960s, saw Washington County as a place with better opportunities for themselves and their families. Mexican immigrant narrators were of diverse educational and vocational backgrounds, and had to weigh different benefits and costs in deciding to leave Mexico. 
While Ariadna Covarrubias Ornelas, Laura Gamboa, and Giores relocated on the grounds of economic necessity and/or the need to reunite with family members who migrated out of economic necessity, Arturo Villaseñor and Eduardo Corona left behind fairly comfortable lifestyles in moving to Washington County. Villaseñor and Corona noted the social and educational benefits that life in Washington County brought to themselves and their families, Covarrubias Ornelas saw her talents recognized in primary, secondary, and post-secondary education, and both Giores and Gamboa expressed hope in improving opportunities for themselves and their families.

Mexican immigrant narrators voiced acknowledgement and respect for Centro Cultural of Washington County and Virginia Garcia Memorial Health Center that the early tejano settlers were largely responsible for creating. The groundwork laid by the early tejano and other early community leaders continued to encourage the welcoming of newcomers. New arrivals, in turn, contributed to what Hector Hinojosa called cultural replenishment-helping settled Latino residents to honor and preserve their language and cultures of origin. 


\section{Conclusion}

Mexican/Latino community building and activism in Washington County, began in the 1960s by tejano families and continued by other Latino settlers, provided a foundation to combat discrimination and assist subsequent migrants and immigrants. Prompted by poor treatment and poor financial prospects and job opportunities, essentially the same factors that motivated subsequent groups of migrants to relocate, tejano families left Texas for seasonal agricultural work in other states. The stresses and uncertainties of seasonal migration encouraged some of these families to settle permanently in new homes. The tejano narrators that settled in the 1960s noted that Washington County and Oregon offered some comparative advantages over other places of residence. Tejano families found community building imperative as they struggled to retain their culture in a region largely unfamiliar with, and often indifferent or hostile to, ethnic Mexicans and other Latinos. The Chicano Movement of the late 1960s and 1970s influenced and furthered their community building efforts.

Because many of them possessed U.S. citizenship, had some level of familiarity with English-speaking U.S. culture, had time to adjust to life in Washington County before the arrival of the Mexican and Latin American immigrant families, and had worked together to create community in the mid-1960s, members of the early tejano families were well equipped to assume positions of leadership to serve the growing ethnic Mexican/Latino population of the county. The 2012 election of Texas-born Joseph Gallegos to the Oregon State Legislature as Hillsboro's representative, the first Latino to be elected to such a position in the county, is one 
example of the relative success and lasting influence of this ethnic Mexican subgroup. Beginning in the 1970s, tejanos in Washington County occupied positions as cultural and linguistic brokers between Latino immigrants and white residents. These niche positions allowed many tejanos to advance professionally and improve opportunities for themselves and their children as they provided necessary services to new arrivals.

While Sister Ina Marie Nosack recalled that some tejanos in the county abused their power in migrant camps, Evangelina Sanchez, the Hernandez family, the Hinojosa family, and many others worked in visible leadership capacities and went out of their way to assist migrants and other community residents. Because these tejanos were from similar socioeconomic backgrounds as most Latino immigrants and first responded to large-scale immigration from Latin America after the beginning of the Chicano Movement, at a time when ethnic solidarity was encouraged, these community builders welcomed immigrants instead of seeking to differentiate themselves from them-as Mexican American elites had done in many communities of the Southwest during the first half of the twentieth century. Increasingly, people from other Southwest states and Mexico-like Lorenzo Rubio, Eduardo Corona, and Arturo Villaseñor-also worked in capacities that aided the Latino population.

Beginning in the 1970s, tejanos struggled with how best to accept Mexican and other Latino immigrants and the accompanying social changes they brought. Early immigrants, in turn, faced similar challenges in relating to new waves of Latino immigrants in subsequent decades. Language and shared experiences of 
mistreatment helped motivate community builders like Emilio and Hortencia Hernandez and the Hinojosa family to welcome Latino newcomers. By the 1990s and 2000s, due in part to community building efforts, new arrivals found a host of opportunities available to them that had not existed for settlers in decades past. These new opportunities did not erase the longstanding problems of social discrimination, economic marginalization, and mistreatment from employers, but they did provide methods for confronting these problems for seasonal migrants and new and long-settled residents alike.

The impact of the tejano settlers extended beyond Centro Cultural and Virginia Garcia. The experiences of Ariadna Covarrubias Ornelas and the children of Eduardo Corona in Washington County schools compared favorably to the school experiences of Hector Hinojosa and Enedelia Hernandez Schofield. A changed social climate that encouraged greater acceptance and respect for students of different ethnic and linguistic backgrounds was brought about in part by actions like those of Evangelina Sanchez and other parents who weathered the backlash of some white residents in order to combat discrimination at Forest Grove schools. Hector Hinojosa helped Latino and other disadvantaged youth obtain GEDs, graduate from high school, and pursue college education. He also worked to help universities and businesses adopt more culturally and linguistically sensitive policies. As an elementary school principal, Enedelia Hernandez Schofield encouraged the success of Latino and other minority students. Evangelina Sanchez continued to work with Latino families of diverse backgrounds. Laura Gamboa's mother and Giores benefitted directly from the material assistance provided by Centro Cultural, where 
all three tejano narrators worked and volunteered their efforts. These tejanos helped bring about better treatment of, and respect for, ethnic Mexicans and other Latino migrants and immigrants.

Community was being continually remade by successive waves of migrants and immigrants. Newcomers contributed heavily to the rapid growth of the county's Latino population. In 2013 and 2014, community did not exist in the tight-knit way that characterized the relationships between the first settler families of the 1960s, but the influx of immigrants assisted in cultural replenishment for the Spanishspeaking population. By actively practicing the cultures of their home communities, new arrivals encouraged settled Latinos to further honor their own identities. Longsettled and newly arriving Latinos benefitted in different ways from the presence of each other.

New immigrants offered new opportunities for community building. Narrators spoke of interacting and forming friendships with immigrants from diverse Latin American backgrounds and with immigrants from non-Latin American countries of origin. Though acknowledging the existence of racism and discrimination, narrators also recalled favorable interactions and friendships with white residents, the type of interactions that Centro Cultural's founders had long endeavored to cultivate. Most Mexican immigrant narrators expressed a desire to better understand county residents of other ethnic and linguistic backgrounds. They valued creating community with the other county residents with whom they interacted on a regular basis. 
Due to time limitations in my research, I was only able to touch on the surface of many issues of historical and contemporary importance to the county's Latino population. I was unable to interview Latino residents from Central America, South America, or the Caribbean, and also unable to interview any Latinos who identified as indigenous. Many of these residents would have likely offered different perspectives on community and on the life opportunities available to them in the county. I was also unable to interview people currently employed in seasonal agricultural work (though four of the narrators had performed such work in the past and two had family members who had performed such work). I was able to examine how life opportunities had changed since the 1960s for people who had managed to settle year-round in the county. Without interviewing narrators who were still migrating seasonally, I was not able to provide a comparable examination of the experiences of current migrants or analyze the ways migrant living and working conditions and opportunities had changed since the 1960s. Further work interviewing and researching the county's non-Mexican Latinos, indigenous Latin Americans, and current migrants would provide a more comprehensive look at the county's Latino population. I also did not ask questions relating to citizenship and residency, or examine what opportunities were or were not available to county Latinos with respect to their different legal statuses in the United States.

Although I was able to explore only certain facets of the history of the county's Latino population with the time and resources allotted to me, this work does represent my efforts to sketch a broad history of this group by earnestly seeking dialogue and the exchange of information with its members. Those 
exchanges encouraged me to think differently and more broadly about the histories of this population. I hope that our interviews, along with my conclusions and the topics highlighted for further research, encourage others to more fully explore the many facets of the under-researched histories of Washington County's Latinos. 


\section{Bibliography}

\section{Primary Sources}

1990 Census of Population: General Population Characteristics of Oregon. U.S. Census Bureau, Washington, D.C.: U.S. Government Printing Office, 1992.

2013 State Profile Oregon: State and County Projections to 2040. Woods \& Poole Economics, Washington D.C.: Woods \& Poole Economics, 2013.

Bania, Jessica. "79 Commence from Centro Cultural." Portland Tribune. Accessed June 3, 2010. Online at http://cni.pmgnews.com/component/content/article?id=30959.

Boone, Jerry F. "Immigrants Same as Others Who Had Dream." Oregonian, December 9, 2006.

Castillo, Andrea. "Parent Group Helps Bridge Culture Gap, Support Education." Oregonian, December 19, 2012.

Castillo, Andrea. "Retiring Officer Leaves Legacy of Helping Others." Oregonian, January 5, 2013.

Castillo, Andrea. "Stable Roots Help Students Flourish: Knowing that Repeated Moves Create Hardships for Kids, Migrant Families in Oregon Find Places to Settle." Oregonian, October 30, 2013.

Chuang, Angie. "Diversity Comes to Oregon." Oregonian, March 18, 2001.

“Cornelius city, Oregon," U.S. Census Bureau, 2010 Census. Accessed April 22, 2014. Online at http://factfinder2.census.gov/faces/tableservices/jsf/pages/productview.xhtml?pi d=DEC_10_DP_DPDP1.

“Council Holds Firm on Center Parking." Oregonian. October 6, 1981.

Dang, Shirley. "Hillsboro Schools Reach Out to Latino Parents-The District Opens an Office for Hispanic Outreach, Aimed at Bolstering Efforts to Close an Achievement Gap." Oregonian, October 23, 2003.

Emilio Hernandez, oral history interview with Michael O'Rourke (Hillsboro, Oreg., March 22, 2000). Transcription in possession of the Washington County Museum. 
Enedelia Hernandez Schofield, oral history interview by Michael O'Rourke (Hillsboro, Oreg., March 22, 2000). Transcription in possession of the Washington County Museum.

Evangelina Sanchez, email to author. November 26, 2013.

Giores, email to author. November 6, 2013.

Gonzalez, Christine. "Hispanics in Washington County Find More (Businesses Offering Familiar Goods).” Oregonian, March 9, 1995.

Gonzalez, Cristine. "The Brothers Rubio Use Radio Show to Meet the Needs of Latinos." Oregonian, June 4, 1998.

Gunderson, Laura. "Washington County Studies Chance of Buying Troubled Migrant Camp." Oregonian, December 5, 2002.

Haffey, Patrice. “Migrant Fund to Help Workers Return Home.” Oregonian, June 27, 1978.

Harrington, Deedee. “Raiders Nab Illegal Aliens.” Oregonian, June 20, 1985.

Hector Hinojosa, oral history interview by Michael O’Rourke (Hillsboro, Oreg., March 15, 2001), transcription in possession of the Washington County Museum.

House, Kelly. "Improving Lives Through Education.” Oregonian, March 26, 2011.

Hughes, Harold. “Senate Votes to Restrict Farm Picketing.” Oregonian, April 26, 1961.

Laatz, Joann. “Farm Pays \$26,000 Settlement.” Oregonian, July 17, 1986.

Lund, Diane. "Conditional-Use Permit Voted for New Building." Oregonian, September 15, 1981.

Lund, Diane. “Decision Reversed on Housing Permit.” Oregonian, April 4, 1982.

Lund, Diane. "Forest Grove Residents Protest Migrant Housing Proposal." Oregonian, September 22, 1981.

Lund, Diane. “Migrant Scarcity Hurting Farmers.” Oregonian, June 9, 1981.

Lund, Diane. "Migrant Worker Housing Projects to be Discussed." Oregonian, August 20, 1981. 
Marroquin, Art. "Migrant Youths Crowd Bilingual Summer School." Oregonian, July 22, 1998.

Martinez Starke, Amy. "Life Story—Emilio Hernandez." Oregonian, February 11, 2007.

Mayer, James. “Jury Selection Starts in Assault Trial.” Oregonian, December 15, 1982.

Mayer, James. “Wage Dispute Said Cause of Farm Worker Assault.” Oregonian, December 16, 1982.

McCarthy, Nancy. "Influx of Field Laborers Swamps Agencies.” Oregonian, June 5, 1988.

McCarthy, Nancy. "Lure of Jobs, Food, Shelter Brought Migrants North." Oregonian, July 10, 1988.

“Mexican-American Men Say Their People Give Full Value.” Oregonian, June 13, 1976.

“Migrants Win Damage Suit.” Oregonian, December 14, 1971.

“Mixtecs in Oregon.” Oregonian, February 13, 1994.

National Institute of Statistics and Geography (INEGI), accessed through Google Public Data Explorer, updated 27 September 2013. Accessed February 21, 2014.

Online at

http://www.google.com/publicdata/explore?ds=z83fj27m8fa7gq_\&hl=en\&dl=en\#! ctype $=l \&$ strail $=$ false $\& b c s=d \& n s e l m=h \& m e t \_y=$ population \&scale_y=lin\&ind_y $=$ false \&rdim=country\&idim=country:Estados+Unidos+Mexicanos\&idim=state:BC\&ifdim= country\&tstart=-

1889020800000\&tend=1266739200000\&hl=en_US\&dl=en\&ind=false.

Navas, Melissa. “College Struggles to Give Away \$1.5 Million in Aid." Oregonian, June $18,2007$.

Olmos, Robert. “Award-Winner Says Migrant Housing Need Great.” Oregonian, July $31,1984$.

Olmos, Robert. "Chicanos Fight Hard for Acceptance while Maintaining Cultural Traditions." Oregonian, July 13, 1976.

Olmos, Robert. “County Farm Labor Progress Seen as Lagging.” Oregonian, July 17, 1986. 
Olmos, Robert. "Former Migrant Mexican Farmworker Seeks Means to Assist Other Seasonal Laborers." Oregonian, June 22, 1966.

Olmos, Robert. "New Health Director to Expand Care for Migrants." Oregonian, January 24, 1984.

Olmos, Robert. "Rural Health Clinic Treats Migrants: Hospital, Group Join Forces.” Oregonian, July 13, 1975.

Olmos, Robert. "State Will Handle Funding of Farm Worker Program." Oregonian, April 2, 1976.

Oral history interview with Ariadna Covarrubias Ornelas, June 12, 2013, Cornelius, Oreg., in author's possession and in the possession of the Washington County Museum.

Oral history interview with Arturo Villaseñor, November 11, 2013, Hillsboro, Oreg., in author's possession and in the possession of the Washington County Museum.

Oral history interview with Eduardo Corona, September 11, 2013, Hillsboro, Oreg., in author's possession and in the possession of the Washington County Museum.

Oral history interview with Enedelia Hernandez Schofield, August 28, 2013, Portland, Oreg., in author's possession and in the possession of the Washington County Museum.

Oral history interview with Evangelina Sanchez, August 2, 2013, Hillsboro, Oreg., in author's possession and in the possession of the Washington County Museum.

Oral history interview with Giores, October 3, 2013, Hillsboro, Oreg., in author's possession and in the possession of the Washington County Museum.

Oral history interview with Hector Hinojosa, July 29, 2013, Hillsboro, Oreg., in author's possession and in possession of the Washington County Museum.

Oral history interview with Laura Gamboa, October 17, 2013, Hillsboro, Oreg., in author's possession and in the possession of the Washington County Museum.

Oral history interview with Sister Ina Marie Nosack, May 9, 2013, Beaverton, Oreg. in author's possession and in the possession of the Washington County Museum.

Ortiz, Fiona M. “Born-Again Hispanics.” Oregonian, November 26, 1995.

Ota, Allen. “To Pick Pears Growers Seek Foreign Workers.” Oregonian, July 16, 1978. 
Painter Jr., John. “Farmer Sentenced to Prison.” Oregonian, May 21, 1988.

Painter Jr., John. "Oregon Farm Manager Admits Alien-Smuggling Conspiracy.” Oregonian, February 17, 1988.

Parker, Paige. "The Monday Profile Latina Principal Hugs Her Way Into Students' Hearts." Oregonian, April 8, 2002.

“Police-Hispanic Gap Needs Bridging.” Oregonian. September 7, 1982.

Pulaski, Alex. "Hovels for the Harvest: Lack of Farm Checks Feeds Camp Squalor." Oregonian, July 19, 1998.

Rede, George. “Farmowner Agrees to Pay \$185,000 to Migrant Workers.” Oregonian, June 24, 1992.

“Ronald Paul Tankersley.” Hillsboro Argus Obituaries, August 2, 2011. Accessed March 4, 2014. Online at http://www.oregonlive.com/argus/index.ssf/2011/08/ronald_paul_tankersley.htm l.

Schulz, J. Blaine. "Oregon to Get Corps to Aid Farm Migrants." Oregonian, March 20, 1965.

Smith, Jill. "Latinos Feel Shortage of Services in County." Oregonian, November 4, 1999.

"Social Agencies Crowd Field in Try to Aid Migrants." Oregonian, September 19, 1965.

"Stable Roots Help Students Flourish: Knowing that Repeated Moves Create Hardships for Kids, Migrant Families Find Places to Settle." Oregonian, October 30, 2013.

“Suburban Roundup.” Oregonian, October 27, 1981.

“Suburban Roundup.” Oregonian, September 8, 1981.

Suo, Steve. “Companies Target Surging Latino Market.” Oregonian, May 20, 2001.

Taylor, Fred G. “Official's Story of Migrants Draws Challenge by Solon.” Oregonian, October 1, 1952.

Taylor, Kate. “Oaxaca and Oregon.” Oregonian, April 23, 1995. 
“U.S. Attorney Checks Farm Dispute Claims.” Oregonian, August 12, 1969.

"Washington County Berry Grower Ruled Guilty of Breaching Migrant Pact." Oregonian, August 14, 1970.

"Washington County, Oregon." Google Maps. Accessed May 29, 2014. Online at https://maps.google.com/maps?q=washington+county\&ie=UTF-

8\&hq=\&hnear $=0 \times 549567$ c85afdc2e7:0x33f5aee1971bf62b,Washington + County,+0 R\&gl=us\&ei=UoqHU6Z_lbPIBITkgJAJ\&ved=0CHsQtgMwDg.

"Washington County, Oregon." U.S. Census Bureau, 2000 Census. Accessed May 8, 2014. Online at

http://factfinder2.census.gov/bkmk/table/1/en/DEC00_SF1/DP1/0500000U5410 67.

"Washington County, Oregon." U.S. Census Bureau, 2010 Census. Accessed April 22, 2014. Online at

http://factfinder2.census.gov/faces/tableservices/jsf/pages/productview.xhtml?pi d=DEC_10_SF1_QTP10.

Whitten, Harry A. "Farm Labor: It's Back to Normal After War Emergency." Oregonian, January 11, 1948.

"Workers Suit Against Berry Farmer Charges Contract on Wages Broken." Oregonian, August 26, 1969.

\section{Secondary Sources}

"About Virginia Garcia Memorial Health Center." Virginia Garcia Memorial Health Center. Accessed January 28, 2014. Online at http://www.virginiagarcia.org/about/index.html.

Acuña, Rodolfo. Occupied America: A History of Chicanos. Boston: Pearson, 2010.

Allegro, Linda and Andrew Grant Wood. Latin American Migrations to the U.S. Heartland: Changing Social Landscapes in Middle America. Urbana: University of Illinois Press, 2013.

Alonzo, Armando C. Tejano Legacy: Ranchers and Settlers in South Texas, 1734 - 1900. Albuquerque: University of New Mexico Press, 1998.

Badillo, David A. Latinos in Michigan. East Lansing: Michigan State University Press, 2003. 
Cardenas, Gilberto, editor. La Causa: Civil Rights, Social Justice, and the Struggle for Equality in the Midwest. Houston: Arte Publico Press, 2004.

Casas, Mary Ann. “Moreno vs. Tankersley: The Migrant Class Action of 1969.” University of Oregon Libraries, 2005.

De Anda, Roberto M. Chicanas and Chicanos in Contemporary Society. Lanham, Md.: Rowan and Littlefield Publishers, Inc., 2004.

Fink, Leon. The Maya of Morganton: Work and Community in the Nuevo New South. Chapel Hill: University of North Carolina Press, 2003.

Foley, Neil. The White Scourge: Mexicans, Blacks, and Poor Whites in Texas Cotton Culture. Berkeley: University of California Press, 1998.

Frisch, Michael. A Shared Authority: Essays on the Craft and meaning of Oral and Public History. Albany: State University of New York Press, 1990.

Gamboa, Erasmo and Carolyn M. Buan, editors. Nosotros: The Hispanic People of Oregon. Essays and Recollections. Portland: Oregon State University Press, 1995.

Gamboa, Erasmo, editor. Voces Hispanas: Excerpts from the Idaho Hispanic Oral History Project. Boise: Idaho Commission on Hispanic Affairs and Idaho Humanities Council, 1992.

Gamboa, Erasmo. Mexican Labor and World War II: Braceros in the Pacific Northwest, 1942 - 1947. Seattle: University of Washington Press, 1999.

Garcia, Jerry and Gilberto Garcia, editors. Memory, Community, and Activism: Mexican Migration and Labor in the Pacific Northwest. East Lansing, Mich.: Julian Samora Research Institute, 2005.

Gonzales-Berry, Erlinda and Marcela Mendoza. Mexicanos in Oregon: Their Stories, Their Lives. Corvallis: Oregon State University Press, 2010.

Gutiérrez, David. Walls and Mirrors: Mexican American, Mexican Immigrants, and the Politics of Ethnicity. Berkeley: University of California Press, 1995.

"History \& Values." Adelante Mujeres. Accessed March 11, 2014. Online at http://www.adelantemujeres.org/history-values/.

Lewis, Catherine M. The Changing Face of Public History: The Chicago Historical Society and the Transformation of an American Museum. DeKalb, Ill: Northern Illinois University Press, 2005. 
Maldonado, Carlos S. and Gilberto Garcia, editors. The Chicano Experience in the Northwest. Dubuque, Iowa: Kendall-Hunt Publishing Company, 1995.

May, Glenn Anthony. Sonny Montes and Mexican American Activism in Oregon. Corvallis: Oregon State University Press, 2011.

Millard, Ann V. and Jorge Chapa. Apple Pie \& Enchiladas: Latino Newcomers in the Rural Midwest. Austin: University of Texas Press, 2004.

Orme, Jr., William A. Understanding NAFTA: Mexico, Free Trade, and the New North America. Austin: University of Texas Press, 1996).

Rodriguez, Marc. The Tejano Diaspora: Mexican Americanism and Ethnic Politics in Texas and Wisconsin. Chapel Hill: The University of North Carolina Press, 2011.

Rogers, Kim Lacy. Life and Death in the Delta: African American Narratives of Violence, Resilience, and Social Change. New York: Palgrave Macmillan, 2006.

Rubenstein, Anne. "Mass Media and Popular Culture in the Twentieth Century." In The Oxford History of Mexico, ed. Michael C. Meyer and William H. Beezley. New York: Oxford University Press, 2000. 637.

Slatta, Richard. "Chicanos in Oregon: A Historical Overview." MA thesis, Portland State University, 1974.

Slatta, Richard. "Chicanos in the Northwest: An Historical Overview of Oregon's Chicanos.” Aztlan: A Journal of Chicano Studies 6 (1975): 327 - 340.

Thurber, Amie. "The History of the Latino People of Washington County: Weaving Community." Unpublished paper for Masters of Education Program, University of Montana, 2012.

Vasquez, Jessica M. Mexican Americans Across Generations: Immigrant Families, Racial Realities. New York: New York University Press, 2011.

Yow, Valerie Raleigh. Recording Oral History: A Guide for the Humanities and Social Sciences. Walnut Creek, Calif.: AltaMira Press, 2005. 
Appendix A: Human Subjects Research Review Committee Approval 


\section{蛋 Portland $\underset{\text { UNIVERSITY }}{\text { State }}$}

Post Office Box 751

Portland, Oregon 972070751
503-725-2227 tel

503-725-8170 fax Human Subjects Research Review Committee hsrrc@lists.pdx.edu

July 1, 2013

To: Luke Sprunger

From: Todd Bodner, HSRRC Chair

Re: $\quad$ HSRRC approval for your project titled, "Mexican-Ancestry Community of Washington County Oral History Project” (HSRRC Proposal \# 132705)

Approval-Expiration:

07/01/2013-

06/30/2014 Review

Type: Expedited,

Categories 6, 7

Dear Luke,

In accordance with your request, the Human Subjects Research Review Committee has reviewed your proposal referenced above for compliance with PSU and DHHS policies and regulations covering the protection of human subjects. The Committee is satisfied that your provisions for protecting the rights and welfare of all subjects participating in the research are adequate, and your project is approved. Signed consent is waived for the survey. Please note the following requirements:

Changes to Protocol: Any changes in the proposed study, whether to procedures, survey instruments, consent forms or cover letters, must be outlined and submitted to the Committee immediately. The proposed changes cannot be implemented before they have been reviewed and approved by the Committee.

Continuing Review: This approval will expire on June 30, 2014. It is the investigator's responsibility to ensure that a Continuing Review Report on the status of the project is submitted to the HSRRC two months before the expiration date, and that approval of the study is kept current. The Continuing Review Report is available at www.rsp.pdx.edu/compliance_human.php and in the Office of Research and Strategic Partnerships (RSP). 
Adverse Reactions and/or Unanticipated Problems: If any adverse reactions or unanticipated problems occur as a result of this study, you are required to notify the Committee immediately. If the issue is serious, approval may be withdrawn pending an investigation by the Committee.

Completion of Study: Please notify the Committee as soon as your research has been completed. Study records, including protocols and signed consent forms for each participant, must be kept by the investigator in a secure location for three years following completion of the study (or per any requirements specified by the project's funding agency).

If you have questions or concerns, please contact the HSRRC in the Office of Research and Strategic Partnerships (RSP) at 503-725-2227, Market Center Building, Suite 620.

cc: Katrine Barber, Advisor 